\title{
Estimation of a Water Budget for 1972-2000 for the Grasslands Area, Central Part of the Western San Joaquin Valley, California
}

By Charles F. Brush, Kenneth Belitz, and Steven P. Phillips

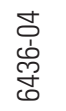

Prepared in cooperation with the U.S. BUREAU OF RECLAMATION

Scientific Investigations Report 2004-5180--Version 1.1 


\section{U.S. Department of the Interior \\ Gale A. Norton, Secretary \\ U.S. Geological Survey \\ Charles G. Groat, Director}

\section{U.S. Geological Survey, Reston, Virginia: 2004}

For sale by U.S. Geological Survey, Information Services

Box 25286, Denver Federal Center

Denver, CO 80225

For more information about the USGS and its products:

Telephone: 1-888-ASK-USGS

World Wide Web: http://www.usgs.gov/

Any use of trade, product, or firm names in this publication is for descriptive purposes only and does not imply endorsement by the U.S. Government.

Although this report is in the public domain, permission must be secured from the individual copyright owners to reproduce any copyrighted materials contained within this report. 


\section{Contents}

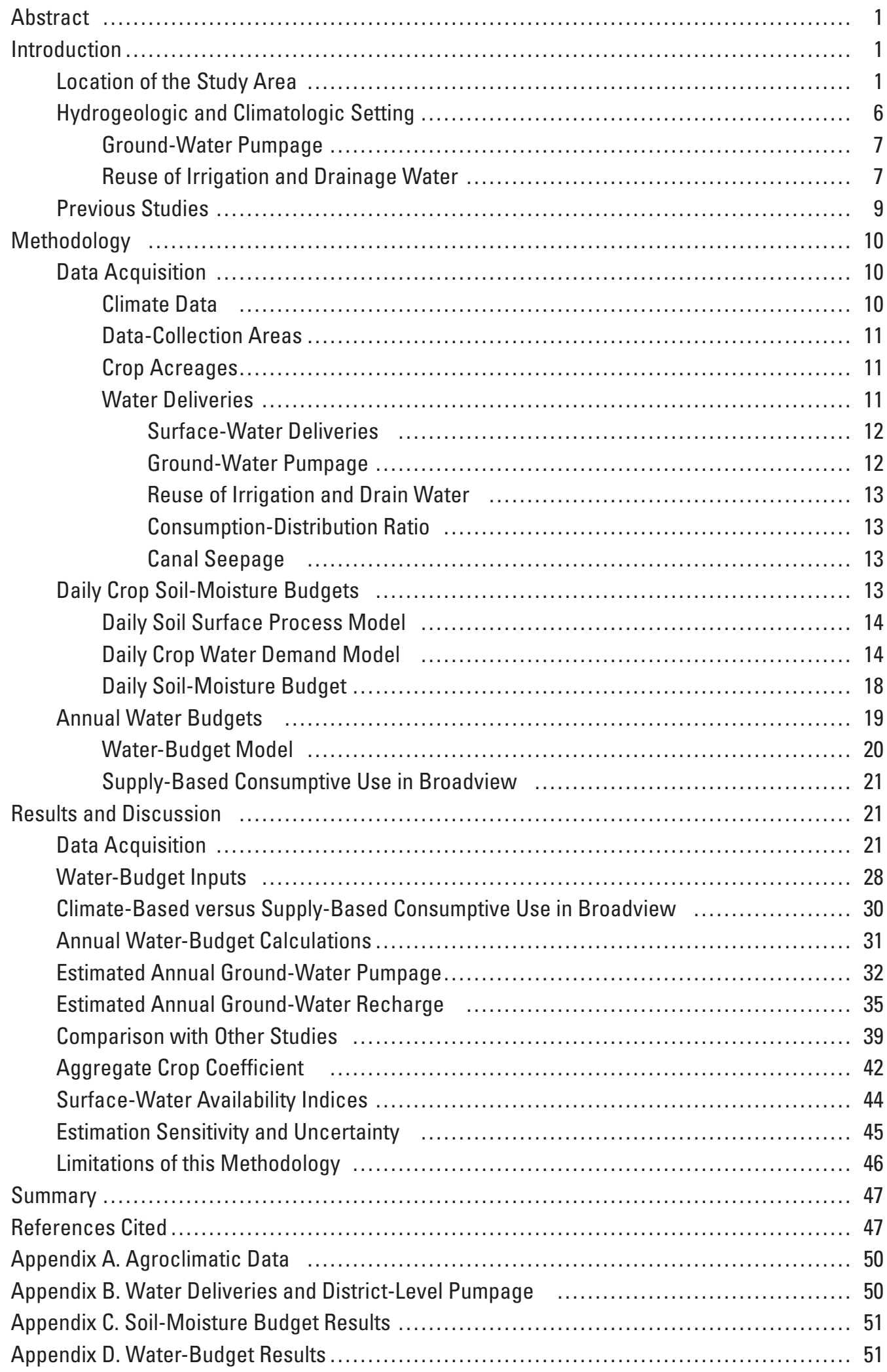




\section{Figures}

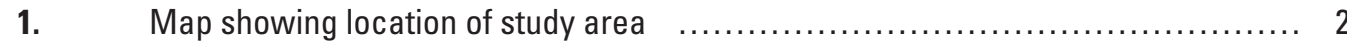

2. Map showing water districts and administrative boundaries within the Grasslands area of the central part of the western San Joaquin Valley, California ... 3

3. Map showing data-collection areas and water-budget areas in the Grasslands area of the central part of the western San Joaquin Valley, California

4. Graph showing changes in surface-water availability in the Grasslands area of the central part of the western San Joaquin Valley, California, water years 1972-2000

5. Graph showing idealized crop coefficient $(K)$ curve expressing the relationship between reference evapotranspiration rate $\left(E T_{0}\right)$ and the evapotranspiration rate for a particular crop $\left(E T_{c}\right)$

6. Conceptual model of the crop-specific daily soil-moisture budget for vegetation types in the central part of the western San Joaquin Valley, California 18

7. Conceptual model of the annual water balance for each water-budget area in the Grasslands area of the central part of the western San Joaquin Valley, California

8. Histogram of 24-hour precipitation for the central part of the western San Joaquin Valley, California, October 1971 to September 2000.

9. Graph showing daily reference evapotranspiration for the central part of the western San Joaquin Valley, California, 1989

10. Graph showing percentage of the total cropped area planted with crops in the Grasslands area of the central part of the western San Joaquin Valley, California, water years 1972-2000

11. Graph showing percentage of the total cropped area planted with crops for water-budget areas in the Grasslands area of the central part of the western San Joaquin Valley, California, water years 1972-2000

12. Graph showing irrigation water delivery rates for water-budget areas in the Grasslands area of the central part of the western San Joaquin Valley, California, water years 1972-2000

13. Graph showing $(A)$ weekly reference evapotranspiration $\left(E T_{0}\right)$ for the central part of the western San Joaquin Valley, California, water years 1972-2000, $(B)$ weekly total crop water demand for the Grasslands area of the central part of the western San Joaquin Valley, California, water years 1972-2000, and (C) weekly reference evapotranspiration, total crop water demand, and unmet crop water demand for the study area for 1989

14. Graph showing crop water demand, crop water demand met with precipitation (effective precipitation), and unmet crop water demand for the Grasslands area of the central part of the western San Joaquin Valley, California, water years 1972-2000

15. Graph showing ratio of the supply-based crop water demand estimate to the climate-based crop water demand estimate for the Broadview water-budget area in the Grasslands area of the central part of the western San Joaquin Valley, California, water years 1972-2000....

16. Graph showing estimated irrigation demand, surface-water deliveries, and estimated ground-water pumpage for the Grasslands area of the central part of the western San Joaquin Valley, California, water years 1972-2000 
17. Graph showing estimated annual ground-water pumpage rates for the waterbudget areas in the Grasslands area of the central part of the western San Joaquin Valley, California, water years 1972-2000

18. Graph showing estimated annual ground-water recharge rates for the waterbudget areas in the Grasslands area of the central part of the western San Joaquin Valley, California, water years 1972-2000 35

19. Graph showing total annual recharge and recharge from surface water, ground water, and precipitation in the Grasslands area of the central part of the western San Joaquin Valley, California, water years 1972-2000

20. Graph showing estimates of annual pumpage rates for $(A)$ the Westlands-S and $(B)$ the Westlands-D water-budget areas in the Grasslands area of the central part of the western San Joaquin Valley, California, water years 1972-2000

21. Graph showing crop coefficient $\left(K_{d}\right)$ for water-budget areas in the Grasslands area of the central part of the western San Joaquin Valley, California, water years 1972-2000

22. Graph showing percentage of acreage cropped, surface-water delivery rates, and estimated ground-water pumpage rates plotted against the cumulative departure from the mean surface water deliveries and the Sacramento Basin 40-30-30-Index for the Grasslands area of the central part of the western San Joaquin Valley, California, water years 1972-2000 


\section{Tables}

1. Cropped acreage and total acreage of data-collection areas and water-budget areas within the Grasslands area of the central part of the western San Joaquin Valley, California

2. Water-budget areas within the Grasslands area of the central part of the western San Joaquin Valley, California

3. Crop coefficients and rooting depths for vegetation types in the central part of the western San Joaquin Valley, California 16

4. Estimated annual ground-water pumpage for the Grasslands area of the central part of the western San Joaquin Valley, California

5. Estimated annual ground-water recharge rates for the water-budget areas of the Grasslands area of the central part of the western San Joaquin Valley, California

6. Estimated average recharge rates from irrigation and precipitation for the Grasslands area of the central part of the western San Joaquin Valley, California, for each of the four delivery periods

7. Water budgets for 1980 and 1984 for several water-budget areas in the Grasslands area of the central part of the western San Joaquin Valley, California

8. Water budgets for 1989 for the Panoche Drainage District in the Grasslands area of the central part of the western San Joaquin Valley, California

9. Recharge estimates for $\mathbf{2 0 0 0}$ for several water-budget areas in the Grasslands area of the central part of the western San Joaquin Valley, California

10. Sensitivities of recharge and pumpage estimates to several input parameters of the water budget of Grasslands area of the central part of the western San Joaquin Valley, California 
CONVERSION FACTORS, AND ABBREVIATIONS

\begin{tabular}{rll}
\hline Multiply & \multicolumn{1}{c}{ By } & To obtain \\
acre & 0.4047 & hectare \\
acre-foot (acre-ft) & 0.001233 & cubic hectometer \\
acre-foot per year (acre-ft/yr) & 0.001233 & cubic hectometer per year \\
acre-foot per year per mile & 0.001233 & cubic hectometer per year per \\
[(acre-ft/yr)/mi] & & \\
foot (ft) & 0.3048 & meter \\
foot per year (ft/yr) & 0.3048 & meter per year \\
inch (in.) & 2.54 & centimeter \\
cubic foot per second (ft $3 / \mathrm{s})$ & 0.02832 & cubic meter per second \\
inch per inch (in/in) & 2.54 & centimeter \\
inch per day (in/d) & 2.54 & centimeter per day \\
inch per year (in/yr) & 2.54 & centimeter per year \\
mile (mi) & 1.609 & kilometer \\
square mile (mi $\left.{ }^{2}\right)$ & 2.590 & square kilometer \\
\hline
\end{tabular}

Temperature in degrees Fahrenheit $\left({ }^{\circ} \mathrm{F}\right)$ may be converted to degrees Celsius $\left({ }^{\circ} \mathrm{C}\right)$ as follows:

$$
{ }^{\circ} \mathrm{C}=\left({ }^{\circ} \mathrm{F}-32\right) / 1.8
$$

\section{Water Year}

A water year is a 12-month period, October through September, designated by the calendar year in which it ends. In this report, years are water years unless otherwise noted.

\section{Abbreviations}

CCID Central California Irrigation District

CDM cumulative departure from the mean

CIMIS California Irrigation Management Information System

CVP Central Valley Project

CWD Canal Water District

DD Drainage District

DMC Delta-Mendota Canal 


$\begin{array}{ll}\text { DWR } & \text { [California] Department of Water Resources } \\ E T_{c} & \text { crop evapotranspiration } \\ E T_{0} & \text { reference evapotranspiration } \\ \mathrm{ft}^{-1} & \text { per foot } \\ \mathrm{ID} & \text { Irrigation District } \\ K_{c} & \text { crop coefficient } \\ K_{d} & \text { aggregate crop coefficient } \\ \text { NCDC } & \text { National Climate Data Center } \\ R & \text { consumption-distribution ratio } \\ \text { SBI } & \text { Sacramento Basin Index } \\ \text { SCS } & \text { [U.S. Department of Agriculture] Soil Conservation Service } \\ \text { SLC } & \text { San Luis Canal } \\ \text { USBR } & \text { U.S. Bureau of Reclamation } \\ \text { USGS } & \text { U.S. Geological Survey } \\ \text { WD } & \text { Water District } \\ \text { WMA } & \text { Waterfowl Management Area } \\ \text { WWD } & \text { Westlands Water District }\end{array}$




\section{Estimation of a Water Budget for 1972-2000 for the Grasslands Area, Central Part of the Western San Joaquin Valley, California}

\author{
By Charles F. Brush, Kenneth Belitz, \\ and Steven P. Phillips
}

\section{Abstract}

Equitable implementation of regulations restricting discharges from agricultural drains into the San Joaquin River requires a greater understanding of the influence of extreme precipitation events on the ground-water flow system. As part of a larger investigation, this study estimated ground-water recharge and ground-water pumpage, two important components of the water budget in the Grasslands drainage area in the central part of the western San Joaquin Valley, California, for the water years 1972 through 2000. These estimates will be used as inputs to a numerical simulation model of the regional ground-water flow system in the continuing investigation. Crop-acreage and surface-water delivery data were compiled for 14 water districts and 6 other areas comprising approximately 97 percent of the 600-square-mile study area. Little ground-water pumpage data exists for the study area. A climate-based approach was employed to estimate annual watertable recharge flux and ground-water pumpage for 11 waterbudget areas. Ground-water pumpage was estimated from the residual irrigation demand after crop consumption of surface water. Estimated recharge flux to the water table for the entire study area averaged $0.8 \mathrm{ft} / \mathrm{yr}$, and estimated ground-water pumpage per unit area for the entire study area averaged 0.5 $\mathrm{ft} / \mathrm{yr}$. Increased discharges from agricultural drains in the late 1990s may have been due partly to 4 years of high recharge from precipitation over the 6-year period from 1993 to 1998. Knowledge of the ratio of annual crop water demand to annual potential evapotranspiration, expressed as an aggregate crop coefficient, $K_{d}$, will facilitate estimation of annual waterbudget components in future studies. Annual aggregate crop coefficients, calculated each year for the entire study area, were nearly constant at 0.59 from 1983 to 2000 , and reasonably constant at 0.53 prior to 1983 . The overall trend suggests continuous reductions in recharge from irrigation over time. This reduction is most likely due to gradual improvements in irrigation management. The recharge and pumpage estimates are both sensitive to the consumption-distribution ratio, and the pumpage estimate is sensitive to the cropped acreage.

\section{Introduction}

Agricultural drainage from lands in the Grasslands drainage area in the central part of the western San Joaquin Valley, California, contains high levels of selenium and other contaminants (Deverel and others, 1984). In August 1999, the California State Water Resources Control Board began implementing regulations to restrict the discharge of selenium from agricultural drains into the San Joaquin River (Letey and others, 2002). Equitable implementation of these restrictions requires a better understanding of the factors that affect the sources, quantity, and quality of agricultural drainage flows. Flow rates from agricultural drains may also be affected by groundwater levels in areas adjacent to the drains, and by seepage from large surface-water delivery canals, smaller district-level canals, and on-farm distribution canals. Environmental factors that may affect drain flows include rate and duration of precipitation and localized flooding owing to discharges from mountain-front streams. Management factors that may affect drain flows include application, recycling, and reuse of irrigation water; cropping patterns and crop water use; and rates and depths of ground-water pumping.

This study is part of an investigation of the hydrology of the Grasslands area. The U.S. Geological Survey, in cooperation with the U.S. Bureau of Reclamation (USBR), is developing a numerical model of the ground-water flow system that can be used to help evaluate the sources and quantity of agricultural drainage discharge. Irrigation water application and ground-water pumpage are the principal driving forces of the ground-water flow system. Estimates of the areal and temporal distributions of recharge and ground-water pumpage are required inputs to the ground-water flow model. This report presents the methods used to estimate annual recharge to the ground-water flow system and annual ground-water pumpage from the system for the water years 1972 through 2000.

\section{Location of the Study Area}

The study area, located in the central part of the western San Joaquin Valley, California (fig. 1), is roughly analogous to the study area of Gronberg and Belitz (1992) with the addition of approximately 235,000 additional acres of land to the north that lies between the Coast Range and a line parallel to and approximately $2.5 \mathrm{mi}$ east of the Delta-Mendota Canal (DMC) (fig. 1). The relatively impermeable sediments of the Coast Range form the western boundary of the study area, and a hypothesized stationary ground-water streamline 


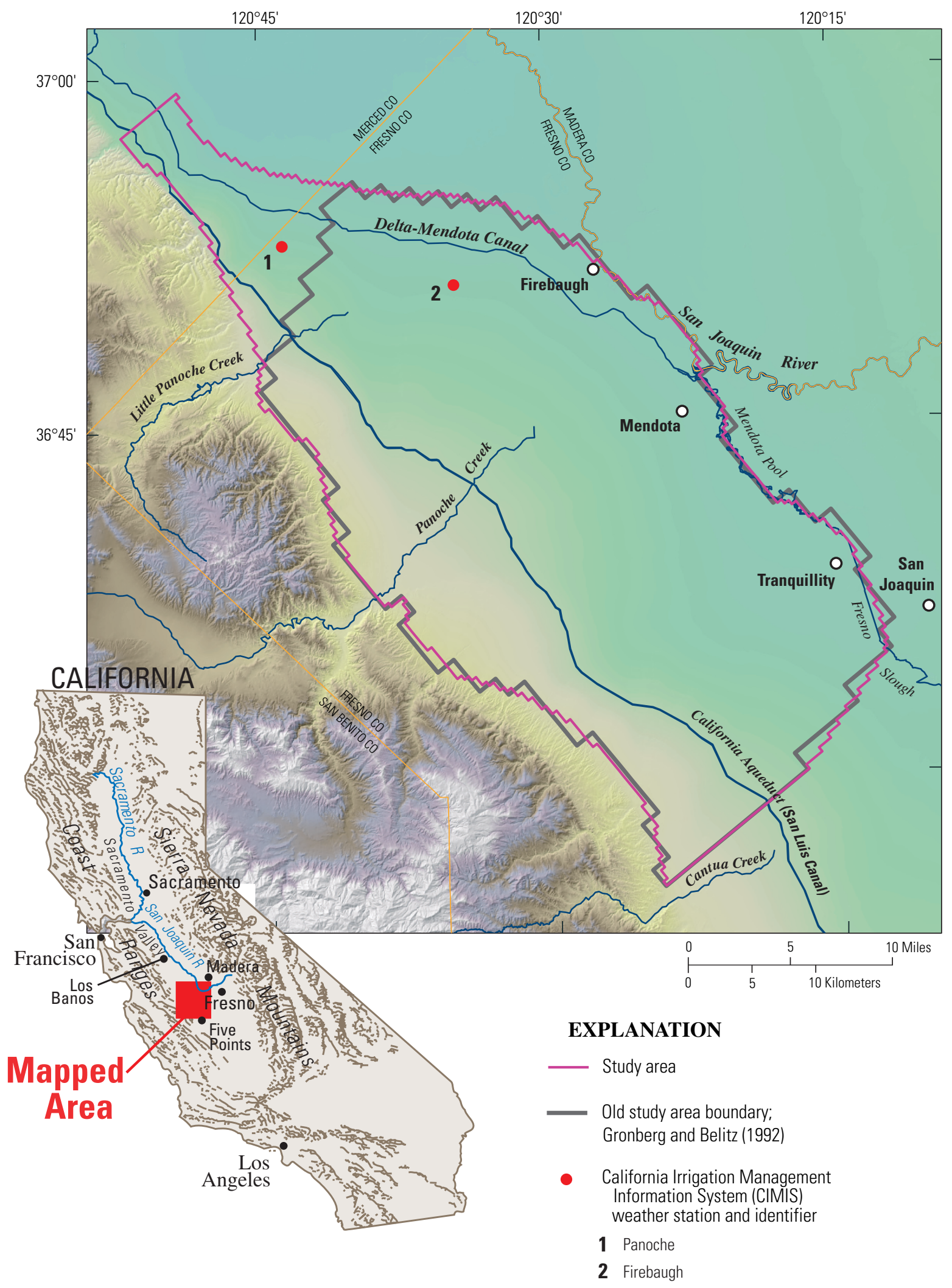

Figure 1. Location of study area. 


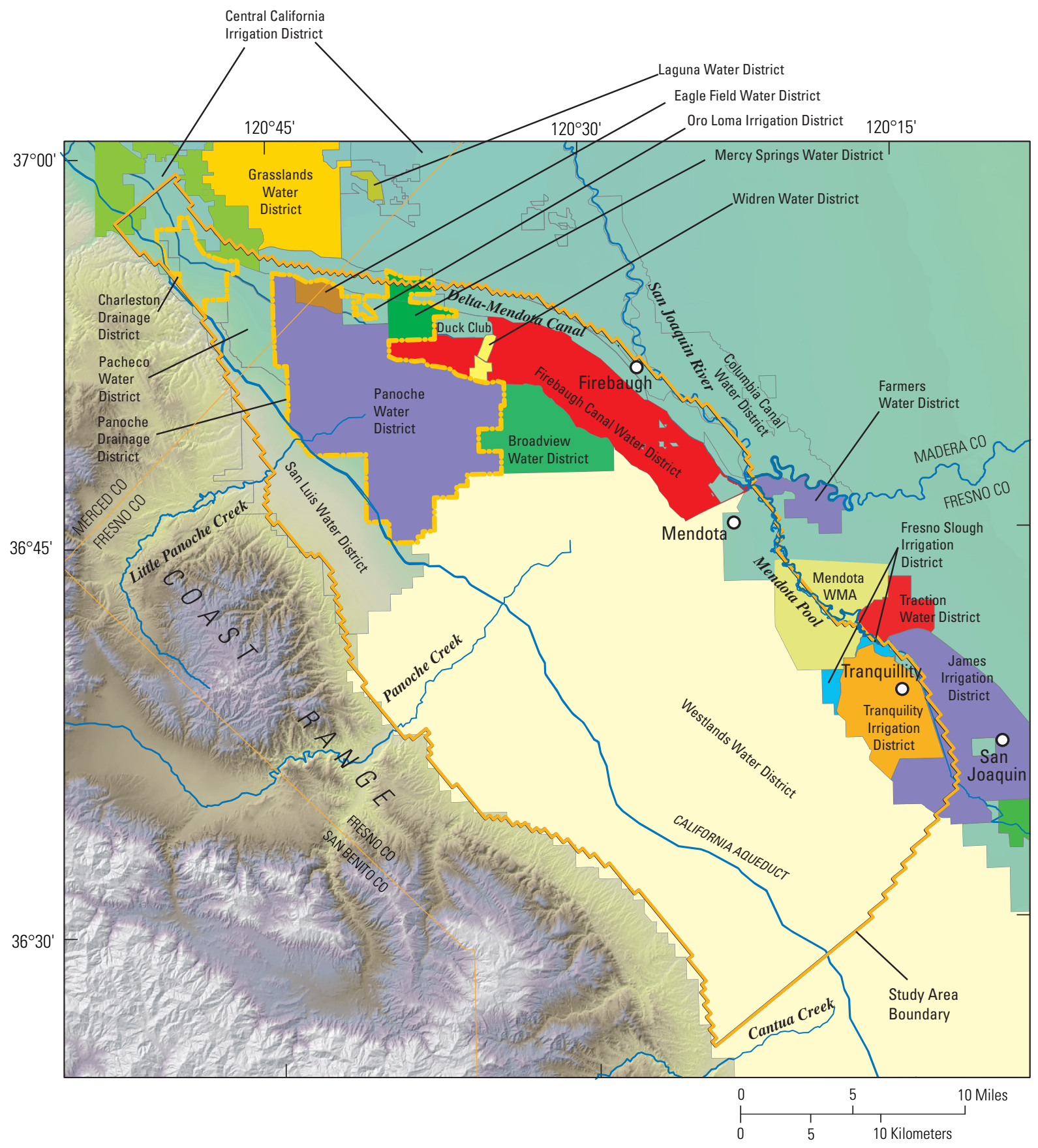

Figure 2. Water districts and administrative boundaries within the Grasslands area of the central part of the western San Joaquin Valley, California.

representing a hydrodynamic no-flow boundary that extends roughly along a line between the point where Cantua Creek exits the Coast Range and through the hamlet of San Joaquin forms the southern boundary. The eastern boundary follows the Fresno Slough, the Mendota Pool, and the San Joaquin River to Firebaugh, north of which the boundary is roughly parallel to, and $2.5 \mathrm{mi}$ east of, the DMC. The northern boundary is a hypothesized stationary ground-water streamline extending from the Coast Range into the valley at a point roughly half way between Los Banos and the Merced-Fresno county line.

The study area includes all or parts of 5 irrigation districts, 9 water districts, and 2 drainage districts, 3 farmed tracts that do not lie within any district, a portion of the Mendota Waterfowl Management Area [WMA], parts of 2 small urban areas (Firebaugh and Mendota), 1 duck club, and some riparian areas with natural vegetation (fig. 2, table 1). Natural surface-water features include Panoche Creek and 
Table 1. Cropped acreage and total acreage of data-collection areas and water-budget areas within the Grasslands area of the central part of the western San Joaquin Valley, California.

[CCID, Central California Irrigation District; DD, drainage district; ID, irrigation district; WD, water district; WMA, Waterfowl Management Area. NW, northwest; SE, southeast]

\begin{tabular}{rlllrr}
\hline $\begin{array}{c}\text { Site identifier } \\
\text { (see figure 3) }\end{array}$ & $\begin{array}{c}\text { Data collection } \\
\text { area }\end{array}$ & $\begin{array}{c}\text { Water-budget } \\
\text { areas }\end{array}$ & Administrative districts & $\begin{array}{r}\text { Cropped area } \\
\text { (acres) }\end{array}$ & $\begin{array}{r}\text { Total area } \\
\text { (acres) }\end{array}$ \\
\hline 1 & Broadview & Broadview & Broadview WD & 8,960 & 9,720 \\
2 & CCID-Camp 13 & CCID-Camp 13 & Central California ID & 5,662 & 5,739 \\
3 & CCID-NW & North & Central California ID & 3,797 & 9,994 \\
4 & CCID-SE & Firebaugh & Central California ID & 2,808 & 2,956 \\
5 & CCID-Charleston & North & Central California ID & 556 & 576 \\
6 & Duck Club & Panoche DD & None & 412 & 432 \\
7 & Eagle Field & Panoche DD & Eagle Field WD & 1,507 & 1,614 \\
8 & Firebaugh & Firebaugh & Firebaugh Canal WD & 23,426 & 24,659 \\
9 & Fresno Slough & Tranquility & Fresno Slough WD & 1,222 & 1,298 \\
10 & James & Tranquility & James ID & 3,962 & 4,293 \\
11 & Mendota WMA & Mendota WMA & Mendota WMA & 6,688 & 7,040 \\
12 & Mercy Springs & Panoche DD & Mercy Springs WD & 3,103 & 3,184 \\
13 & Natural & Mendota WMA & None & 0 & 800 \\
14 & No District & Firebaugh & None & 1,204 & 1,256 \\
15 & Oro Loma & Panoche DD & Oro Loma ID & 1,088 & 1,290 \\
16 & Other Areas & Panoche DD & None & 2,603 & 2,715 \\
17 & Pacheco & Pacheco & Pacheco WD & 4,463 & 4,751 \\
18 & Panoche WD & Panoche DD & Panoche WD & 33,493 & 39,938 \\
19 & Sagouspe & Firebaugh & None & 1,340 & 1,495 \\
20 & San Luis-A & San Luis & San Luis WD & 24,002 & 25,366 \\
21 & San Luis-B & North & San Luis WD & 616 & 635 \\
22 & San Luis-C & North & San Luis WD & 2,121 & 2,239 \\
23 & San Luis-Charleston & North & San Luis WD & 3,861 & 3,981 \\
24 & Tranquility & Tranquility & Tranquility ID & 10,456 & 11,007 \\
25 & Westlands-ID & Westlands-D & Westlands WD & 26,709 & 28,131 \\
26 & Westlands-IS & Westlands-S & Westlands WD & 101,516 & 106,921 \\
27 & Westlands-II & Westlands-D & Westlands WD & 74,357 & 78,316 \\
28 & Westlands-III & Westlands-D & Westlands WD & 3,494 & 3,680 \\
29 & Widren & Firebaugh & Widren WD & 850 & 852 \\
\hline
\end{tabular}

${ }^{1}$ Receives deliveries from the Central California Irrigation District.

${ }^{2}$ Priority area I with deep water table.

${ }^{3}$ Priority area I with shallow water table.

Little Panoche Creek, which originate in the Coast Range and flow from southwest to northeast across the study area. Two large surface-water conveyances, the San Luis Canal (SLC) and the DMC, flow southward through the study area; many smaller canals, operated by irrigation and drainage districts, also are present.

To facilitate data compilation and interpretation, the study area was divided into 29 data-collection areas (fig. 3, table 1).
Many of these areas coincide with an incorporated irrigation district, or water district, or another administrative unit. Several data-collection areas correspond to a portion of a district within the study area. These 29 data-collection areas were consolidated into 11 geographically contiguous water-budget areas for estimation of recharge and ground-water pumping (fig. 3, table 2). 


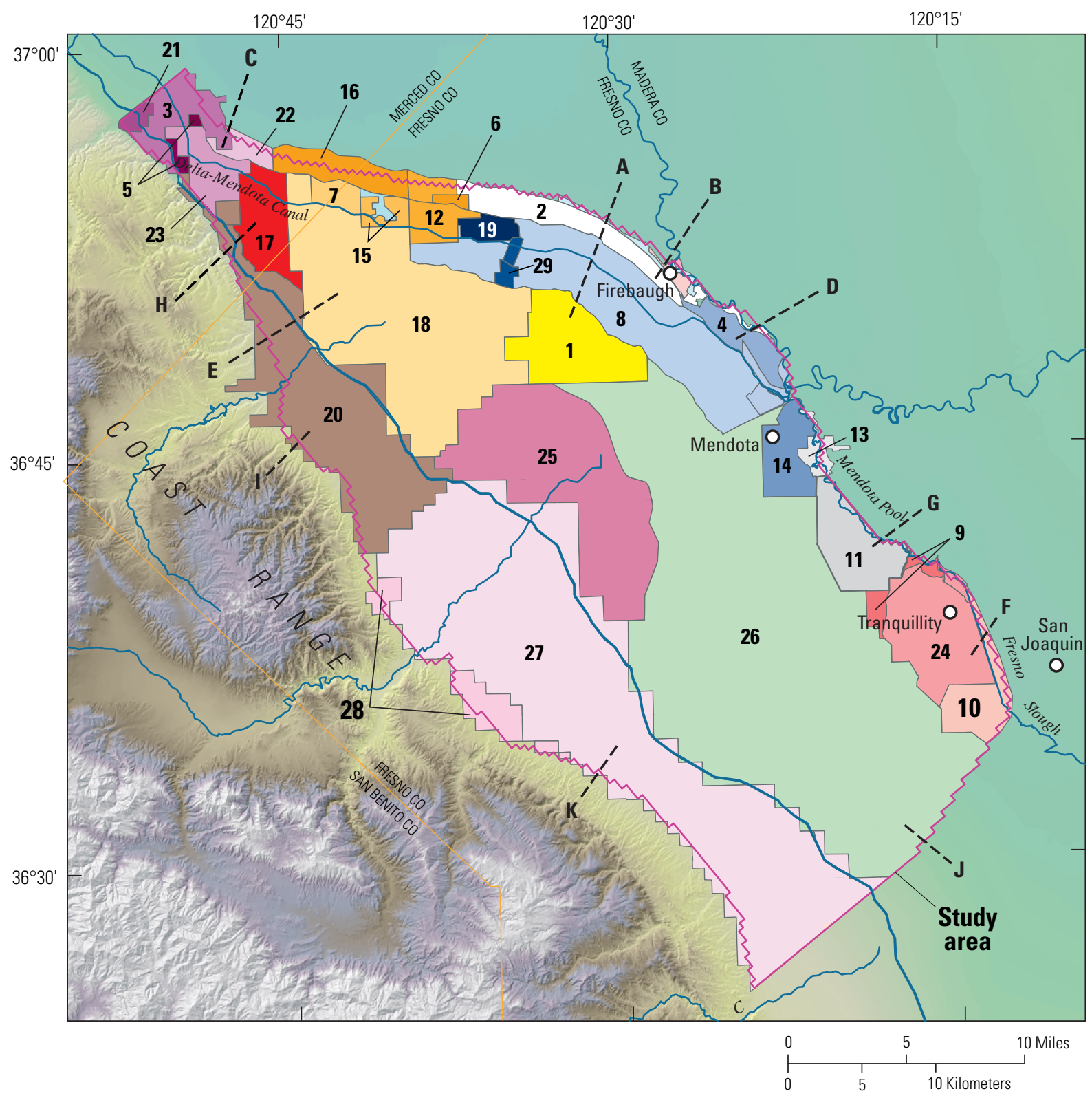

Figure 3. Data-collection areas and water-budget areas in the Grasslands area of the central part of the western San Joaquin Valley, California. Numbers indicate data-collection sites (see table 1 for site names). Letters indicate water-budget sites (see table 2 for site names). 
Table 2. Water-budget areas within the Grasslands area of the central part of the western San Joaquin Valley, California.

[CCID, Central California Irrigation District; DD, drainage district; WMA, Waterfowl Management Area]

\begin{tabular}{llccc}
\hline $\begin{array}{c}\text { Site identi- } \\
\text { fier (see } \\
\text { figure 3) }\end{array}$ & $\begin{array}{c}\text { Water- } \\
\text { budget } \\
\text { area }\end{array}$ & $\begin{array}{c}\text { Total area } \\
\text { (acres) }\end{array}$ & $\begin{array}{c}\text { Ground- } \\
\text { water } \\
\text { pumping }\end{array}$ & $\begin{array}{c}\text { Consump- } \\
\text { tion- } \\
\text { distribution } \\
\text { ratio (R) }\end{array}$ \\
\hline A & Broadview & 9,720 & No & 0.80 \\
B & CCID-Camp 13 & 6,000 & No & .80 \\
C & North & 11,600 & Yes & .78 \\
D & Firebaugh & 36,800 & Yes & .80 \\
E & Panoche DD & 49,400 & Yes & .80 \\
F & Tranquility & 17,200 & Yes & .71 \\
G & Mendota WMA & 7,840 & No & .80 \\
H & Pacheco & 4,760 & Yes & .80 \\
I & San Luis & 25,600 & Yes & .72 \\
J & Westlands-S & 107,200 & Yes & .80 \\
K & Westlands-D & 110,400 & Yes & .70 \\
\hline
\end{tabular}

\section{Hydrogeologic and Climatologic Setting}

Belitz and Heimes (1990) provide a detailed description of the geohydrology of the study area. Their description is summarized here. The San Joaquin Valley is bounded by the Sierra Nevada to the east and the Coast Range to the west. The valley's climate is characterized by cool, wet winters and hot, dry summers. Most precipitation falls between November and March. Daily average temperatures range from 35 to $102^{\circ} \mathrm{F}$ (Gilliom and others, 1989). Annual average precipitation at Firebaugh, Calif., is 8.8 in. for 1972 through 2000, and the annual average reference evapotranspiration is 56 in. for 1983 through 2000 (California Department of Water Resources, accessed June 18, 2002). Because annual precipitation in the study area is too low to meet the water requirements of agricultural crops, supplemental irrigation (imported surface water and ground water) is required to meet crop water needs.

Under natural conditions, precipitation does not contribute significantly to recharge (Belitz and Heimes, 1990). Much of the water flowing in the intermittent streams crossing the study area either infiltrated or evaporated before reaching the San Joaquin River. The water that infiltrated flowed through the ground-water flow system to discharge by evapotranspiration and streamflow along the valley trough.

Much of the land within the study area currently (2004) is irrigated, including large cropped areas and two wildlife areas (Mendota WMA and a duck club), which are irrigated during the winter to provide feed and habitat for waterfowl. The area was first irrigated for agricultural purposes in the 1870s, using surface water from the San Joaquin and the Kings Rivers
(Belitz and Heimes, 1990), establishing riparian water rights on these rivers.

Development of irrigated agriculture has imposed significant changes on the regional hydrologic system. Groundwater pumping started before 1924. By 1950, most of the study area (excluding the areas of the Oro Loma Irrigation District [ID], the Firebaugh Canal Water District [CWD], and the westernmost part of the Westlands Water District [WD]) was irrigated with ground water (Gronberg and Belitz, 1992). Much of this water was pumped from beneath the Corcoran Clay Member of the Tulare Formation (Gronberg and Belitz, 1992) in the western part of the current study area. The amount of ground water pumped from beneath the Corcoran Clay member of the Tulare Formation was much greater than the amount of water that recharged naturally, thus causing potentiometric heads to decline several hundred feet from the assumed pre-development levels (Ireland and others, 1984). This decline in the potentiometric heads caused poor-quality water to flow upward from deeper aquifers. Growers realized that the steadily increasing pumping lifts, land subsidence, and continuing degradation in water quality limited the long-term continued reliance on ground water and, thus, sought more sustainable surface-water supplies.

Surface-water use in the San Joaquin Valley was greatly expanded with the authorization of Federal and State programs in the mid-1900s. The Federal Central Valley Project (CVP) was authorized in 1936, and the DMC was completed in 1952. The San Luis Unit of the CVP, which includes the San Luis Dam, the SLC, the Coalinga Canal, and the San Luis Drain, was authorized in 1960, and the SLC was completed in 1967. CVP deliveries of surface water from the Sierra Nevada to the study area began in the 1940s. The Panoche WD began receiving CVP water in the late 1940s, and the Broadview WD began receiving CVP water in the early 1950s. The Tranquility ID and the Westlands WD entered into long-term contracts to receive CVP water in 1963. The Central California Irrigation District (CCID), the Firebaugh CWD, the Columbia CWD, and the San Luis Canal Company entered into an agreement to exchange their pre-1914 rights to water from the Fresno, the Kings, and the San Joaquin Rivers for CVP water. Today most of the surface water used within the study area originates in the Sierra Nevada and is transported to the area through the Sacramento-San Joaquin Delta and then through either the SLC or the DMC and the Mendota Pool.

As increasing numbers of growers switched from ground water to cheaper and higher quality surface water during the 1960s and 1970s, cropped acreages increased, and more higher value crops were planted. Consequently, the amount of surface water applied increased, ground-water pumping decreased, and the potentiometric surface began to rise. In some parts of the study area, the potentiometric surface in the confined aquifer below the Corcoran Clay rose by as much as 200 to $300 \mathrm{ft}$ from 1967 to 1984 (Gronberg and Belitz, 1992).

Firm surface-water supplies (from contracts in which annual delivery amounts do not vary in response to surfacewater availability, except in years of a critical water shortage) 
are augmented with purchases and transfers of water both from inside and outside the study area. Some districts and growers in the study area supplement available surface-water supplies with ground water; thus, ground-water pumping is still occurring in the study area, especially in drought years when the surface-water allocations to some growers are severely reduced.

Annual changes in surface-water availability in the study area are reflected in two surface-water availability indices: the cumulative departure from the mean surface-water delivery rate (CDM) and the Sacramento Basin 40-30-30 Index (SBI). The CDM value for each year is computed as

$$
C D M_{y}=C D M_{y-1}+S_{y}-\frac{1}{n} \sum_{i=1}^{n} S_{y}
$$

where $C D M_{y}$ is the $C D M$ for water year $y, C D M_{y-1}$ is the $C D M$ value for the previous year, $S_{\mathrm{y}}$ is the amount of surface water delivered in year $y$, and $n$ is the number of years for which data are available. The $S B I$ is computed using the following equation:

$$
S B I_{y}=0.4 x_{1}+0.3 x_{2}+\min \left(S B I_{y-1}, 10\right)
$$

where $x_{1}$ is the unimpaired runoff for April to July of water year $y$ for the Sacramento Valley, $x_{2}$ is the unimpaired runoff for October to March of water year $y, S B I_{y-1}$ is the $S B I$ value for the previous year, and all values are in units of million acre-feet (California Department of Water Resources, accessed March 15, 2004). Unimpaired runoff to the Sacramento Valley is the sum of runoff that would enter the valley from the Sacramento, Feather, Yuba, and American Rivers in the absence of dams. If the SBI is above 9.2 million acre- $\mathrm{ft}$ the year is considered "wet," and if it is below 5.4 million acre-ft the year is considered "critical." SBI values were obtained from the California Department of Water Resources (2003). Annual values for the CDM and SBI indices are plotted in figure 4.

Changes in the rate of change of the CDM index indicate that there were four broad periods of surface-water availability in the study area between 1972 and 2000. The first period was indicated by a rise in the CDM index between 1973 and 1976, as surface-water deliveries from the SLC increased, and then a decrease between 1977 and 1978, owing to drought. The second period of surface-water availability was indicated by a rise in the CDM index between 1979 and 1989, which was an extended period of surface-water abundance. The third period (1990-93) was indicated by a sharp decrease in the index owing to a period of protracted drought; surface-water deliveries were significantly curtailed during this period. The fourth period, 1994-2000, was indicated by a relatively stable CDM index; this was a period when surface-water supplies were significantly lower than they were during the 1980s.

The SBI is an indicator of the amount of surface water stored in reservoirs in a given year. The mean value of the
SBI was 8.3 million acre-ft between 1972 and 2000. The two curves in figure 4 follow roughly similar trends, with the peaks and valleys in the SBI tending to occur several years before corresponding peaks and valleys in the CDM.

\section{Ground-Water Pumpage}

Although crop irrigation water requirements in the study area primarily are met with surface-water imports, they are often supplemented with ground water (Belitz and Heimes, 1990). Little information exists regarding the volumes and timing of ground-water pumping. Significant ground-water pumping is believed to occur in several areas and from both grower-owned and district-owned wells. In years when surface-water deliveries are limited, ground water may be used to meet as much as 60 percent of crop irrigation water requirements within the Panoche WD (Irrigation Training and Research Center, 1994) and 70 percent of crop water requirements within Westlands WD (Westlands Water District, 1999). Pumping wells may be perforated in the unconfined or the semi-confined unit above the Corcoran Clay or in the confined unit below the Corcoran Clay, or they may be partly perforated in both units (Gronberg and Belitz, 1992). For this study, it was assumed that growers pumped additional ground water sufficient to satisfy the crop irrigation water requirement.

Several districts own and operate wells to supplement surface-water deliveries in months of high demand and in years of short water supply. The CCID operates wells in the CCID-SE area, pumping a significant amount of ground water to supplement surface-water deliveries both inside and outside the CCID-SE area (Chris White, Central California Irrigation District, written commun., 2001). The Firebaugh CWD owned 10 wells that were operated in extremely dry years (Irrigation Training and Research Center, 1994); many of these wells ceased production in the 1990s (Joseph McGahan, Summers Engineering, written commun., 2004).

The ground water in several areas is of such poor quality that it cannot be used to irrigate crops. Growers in these areas generally rely on surface-water deliveries and precipitation to provide needed moisture to their crops. No ground-water pumping is believed to occur in the CCID-Camp 13 area, the Charleston DD (within Pacheco WD and San Luis WD), or the Fresno Slough WD. There are no grower-operated wells in the Broadview WD or the Firebaugh CWD.

\section{Reuse of Irrigation and Drainage Water}

Some agricultural drain water is recycled by irrigation districts ("tile water") or on farms ("tail water"). Since 1990, many districts and growers have implemented programs that recycle significant amounts of both tail water and tile water. Two major benefits of recycling are a reduction in supplemental irrigation water to met crop water requirements and a reduction in the amount of drainage water that is discharged. Major drawbacks of recycling are the capital and operation 

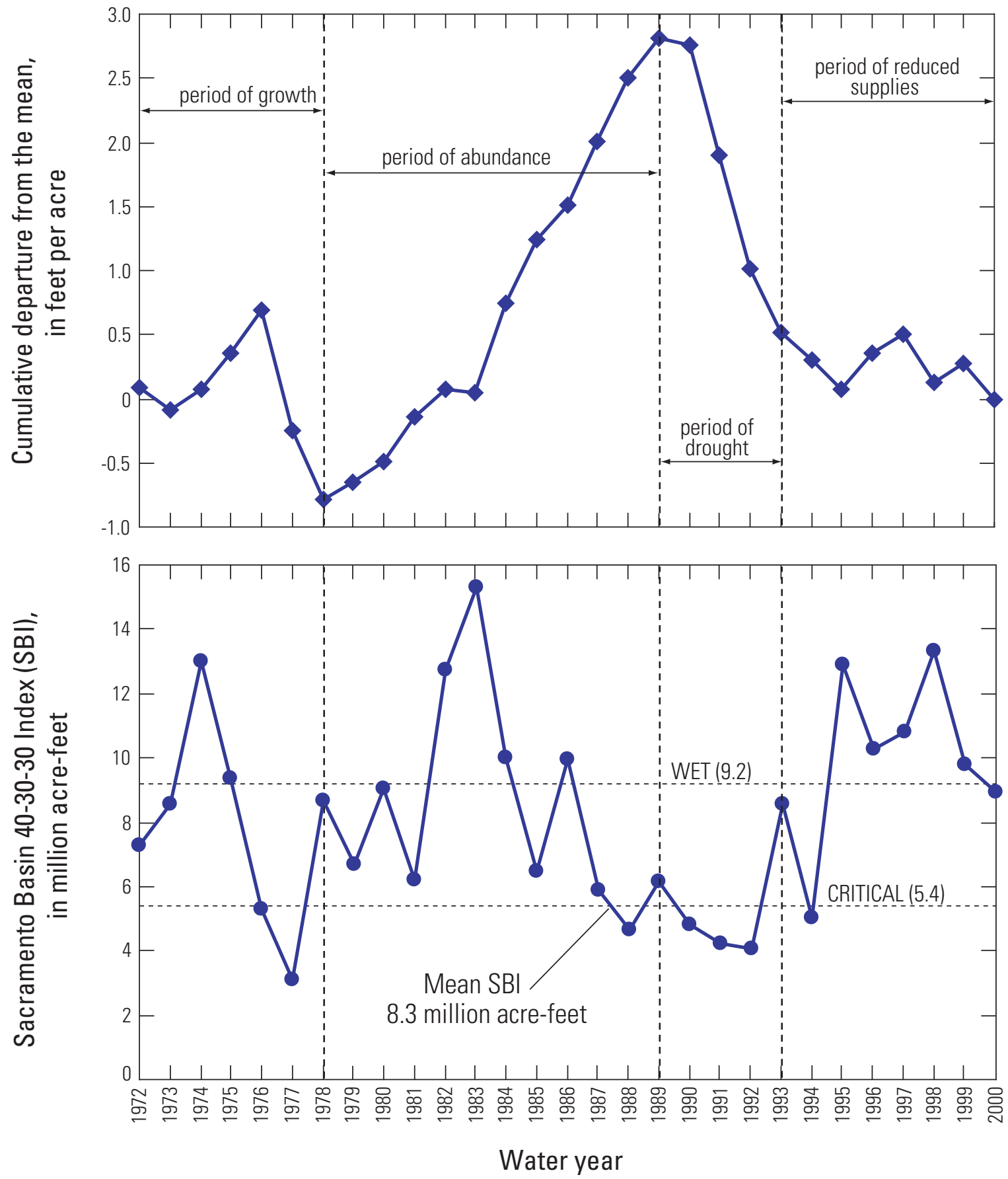

Figure 4. Changes in surface-water availability in the Grasslands area of the central part of the western San Joaquin Valley, California, water years 1972-2000. A, Cumulative Departure from the Mean (CDM). B, Sacramento Basin 40-30-30- Index (SBI). 
costs involved, and the potential that salinity in the root zone can increase to unacceptable levels.

Some districts collect tail water and pump it into district distribution canals to increase the amount of water available for delivery. Low-quality drainage water is added to higher quality irrigation water, resulting in irrigation water of slightly poorer quality. This allows the district to increase water deliveries to growers, especially during times of peak usage, and to simultaneously reduce drainage-water discharges. Districts generally set minimum water-quality standards for irrigation deliveries, which limits the amount of drainage water that can be recycled.

Some districts imposed drainage-water restrictions in the 1990s by mandating changes in farm management practices in an effort to reduce discharges of drainage water within the districts. For example, the Broadview WD and the Firebaugh CWD stopped accepting surface runoff from excess irrigation water applications into their drainage systems, forcing growers to install on-farm tail-water collection and recycling systems.

\section{Previous Studies}

Numerous studies have been undertaken in the study area since the discovery of environmental problems related to selenium in agricultural drainage water in the western San Joaquin Valley in the 1980s (Presser and Barnes, 1985). Water-use studies conducted in this area include those of Burt and Katen (1988), Ayars and Schrale (1989), Gronberg and Belitz (1992), Belitz and others (1993), Fio (1994), Irrigation Training and Research Center (1994), Westlands Water District (1996, 2004), and Summers Engineering (2002).

Burt and Katen (1988) analyzed the results of on-farm irrigation-system evaluations in the Westside Resource Conservation District, which is contiguous with the Westlands WD. Irrigation system evaluations were performed on 83 farm fields comprising approximately 11,000 acres during 1986 and 1987. Burt and Katen (1988) reported that the annual area-weighted irrigation efficiency for the district was 66 percent. They also estimated an average irrigation water application of $2.5 \mathrm{ft} / \mathrm{yr}$ and an average deep percolation of 0.8 $\mathrm{ft} / \mathrm{yr}$ for the district.

Ayars and Schrale (1989) measured irrigation efficiency and subsurface drain flows in the Panoche DD in 1987 and 1988. For that study, they assumed that ground-water pumpage in the district was minimal. They estimated irrigation efficiencies for the Panoche DD of 72 percent in 1987 and 78 percent in 1988. They also found an inverse relationship between irrigation efficiency and soil permeability.

Gronberg and Belitz (1992) used a water-budget approach to estimate the areal distribution of recharge and ground-water pumpage for a study area covering much of the current study area (fig. 1). Crop acreages and estimates of crop consumptive use and effective precipitation, collected in 1980 and 1984, were used to calculate annual crop water requirements for seven water-budget areas. Surface-water deliveries for these areas also were compiled. Gronberg and Belitz (1992) found an inverse relationship between irrigation efficiency and depth to the water table. The annual irrigation water requirement for each water-budget area was estimated as the crop water demand (after utilization of effective precipitation) divided by the irrigation efficiency. Ground-water pumpage was estimated as the irrigation requirement minus the surface-water deliveries. Ground-water recharge was also estimated. Belitz and others (1993) used the results of their study as inputs to a numerical ground-water flow simulation.

Fio (1994) used a steady-state ground-water flow model to calculate a water budget for the Panoche DD for 1988 and 1989. The irrigation-water application rates of Ayars and Schrale (1989) were used in the model. Effective precipitation and bare-soil evaporation rates were estimated using climatic data. Crop water demand was estimated from crop acreages and local crop calendars. Recharge to the saturated zone was calculated as applied irrigation water plus effective precipitation minus crop water demand.

The Irrigation Training and Research Center (1994) estimated annual effective precipitation, crop water demand, and irrigation efficiency for 1981-92 for six water-budget areas representing roughly 80,000 acres: Broadview WD, CCIDCamp 13, Charleston DD, Firebaugh CWD, Pacheco WD, and Panoche DD. Changes in irrigation efficiency from 1981 through 1992 for these water-budget areas were estimated using both a crop consumptive-use approach and a waterbalance approach. Land use was aggregated into 17 crop classes plus a class for fallow land. Monthly crop water demand for each crop class was calculated as the product of monthly total reference evapotranspiration and a monthly aggregate crop coefficient. Effective precipitation for the entire study area was assumed to be equal to one-half the precipitation that fell at Mendota Dam between October 1 and March 31. It was determined that grower estimates of ground-water pumpage did not appear to account for all the water required to grow crops. Annual regional irrigation efficiencies calculated using the crop consumptive-use approach for 1981-92 ranged from a low of 53 percent in 1982 to a high of 78 percent in 1991. Annual regional irrigation efficiencies calculated using the water-balance approach for 1986-92 ranged from a low of 56 percent in 1986 to a high of 78 percent in 1991.

The Westlands WD estimates the total volume of ground water pumped in the district each year using a method they have developed in-house (Westlands Water District, 1996; Westlands Water District, 1999; Thad Bettner, Westlands Water District, written commun., 2004). At the end of each year, the overall district irrigation demand is computed from a water balance using cropping patterns, reference evapotranspiration, and irrigation efficiency estimates. Ground-water pumpage for the year is then estimated as the residual irrigation demand after application of surface water. This estimate is then checked by estimating ground-water pumpage from changes in the depth to the water table, determined from measurements taken through the district's ground-water monitoring program. Since 1999, the district also has monitored flow 
meters installed on pumps supplying approximately 60 percent of the total ground-water pumpage within the district. Irrigation efficiencies used for these calculations vary annually and ranged from 72 to 94 percent between 1978 and 1996, averaging 83 percent (Westlands Water District, 1999).

Summers Engineering (2002) calculated annual deep percolation rates for 1999 for seven areas: Broadview WD, CCID-Camp 13, Charleston DD, Firebaugh CWD, Pacheco WD, Panoche DD, and Westlands WD. They assumed irrigation efficiency was a known function of the irrigation technology used, that the spatial distribution of irrigation technologies within each study area was known, and that $2.6 \mathrm{ft} / \mathrm{yr}$ of irrigation water were applied.

\section{Methodology}

A climate-based approach was used to estimate crop water demand for each water year between 1972 and 2000 for 11 water-budget areas. The climate-based estimates of crop water demand were then used as to estimate ground-water demand and recharge. Inputs to the climate-based model were crop acreages, daily $E T_{0}$, and daily crop $K_{c}$ values. Recharge and irrigation pumpage were estimated using a water budget and a crop consumptive use approach. Crop acreage and evapotranspiration estimates were used to calculate the annual crop water demand for each water-budget area. Effective precipitation was calculated as the portion of infiltrated precipitation available to meet crop water demand. Remaining crop water demand was divided by the consumption-distribution ratio to yield annual crop irrigation water demand. Ground-water pumpage for irrigation, which was not measured in the study area, was assumed to be the difference between crop irrigation water demand estimated in the water budget and the volume of irrigation water from other sources. Irrigation or infiltrated precipitation that exceeded the crop water demand was assumed to be recharge. Travel times through the unsaturated zone and lateral flow were not addressed as part of this study.

The water budget for the study area was developed in three phases. First, annual crop acreages and monthly surfacewater delivery data were collected for the 29 data-collection areas shown in figure 3 and listed in table 1. Second, daily soil-moisture budgets were developed for the study period for 66 crops grown in the study area (including managed waterfowl habitat and fallow as "crops") to calculate annual crop irrigation demand and recharge from precipitation. Bare-soil evaporation other than that from precipitation was not treated explicitly, but was incorporated into the water budget through the consumption-distribution ratio. Third, the crop irrigation demand estimates from the soil-moisture budgets were combined with crop acreage and surface-water delivery data to calculate annual water budgets for the 11 aggregated areas shown in figure 3. Spreadsheets were used to assemble the crop acreage and water delivery databases. The water-budget components were developed using a series of FORTRAN programs.

\section{Data Acquisition}

Water-budget development required the collection of daily climate data and annual crop acreage and surface-water delivery data for the study area. Owing to the limited spatial resolution of these data, geographically contiguous datacollection areas were aggregated into 11 water-budget areas. Development of a consistent data set for crop acreages and surface-water deliveries was hindered by the large assortment of data formats, significant data gaps, limited data regarding surface-water transfers, the lack of public agency records regarding ground-water pumpage from privately owned wells, and the reluctance of private parties to release crop acreage and ground-water pumpage data. Consumptiondistribution ratio estimates and canal seepage rate estimates were also compiled.

\section{Climate Data}

A single daily value for precipitation and for reference evapotranspiration $\left(E T_{0}\right)$ was assumed to apply across the entire study area. Preliminary investigation revealed that the water-budget methodology is relatively insensitive to precipitation and that there is little spatial variation in daily $E T_{0}$ in the study area. Records of daily precipitation, $E T_{0}$, and maximum daily air temperature are available for the California Irrigation Management Information System (CIMIS) stations at Panoche, Firebaugh, and Five Points (fig. l) from their dates of inception. Records of daily precipitation and maximum daily air temperature for the entire study period are also available for the National Climate Data Center (NCDC) stations at Five Points, Los Banos, and Madera (fig. 1).

For each day from January 1, 1970, through December 31,2000 , a single daily precipitation value and a single daily $E T_{0}$ value was assumed to apply across the entire study area. Daily precipitation measurements were available from at least one station for the entire study period. Daily CIMIS $E T_{0}$ estimates, calculated using the Penman-Montieth equation, were used for the period from June 6, 1982, through December 31, 2000. For days when no $E T_{0}$ estimates were available at any stations, including days prior to June 6, 1982, $E T_{0}$ was estimated using a correlation between daily $E T_{0}$ and daily maximum air temperature. The correlation between daily maximum air temperatures and measured $E T_{0}$ at each of the three CIMIS stations was between 69 and 72 percent. No single station had a complete record of precipitation, $E T_{0}$, or air temperature measurements for the entire study period. Records from multiple stations were used to generate a single daily value, assumed to be representative of the entire study area, by selecting the value for each day from the station nearest to the site of the Panoche CIMIS station.

The precipitation measurement used for each day was from the CIMIS station in Panoche, if available, followed by measurements from the CIMIS station in Five Points (39 percent correlation with Panoche), the NCDC station in Five 
Points (26 percent correlation with Panoche), the NCDC station in Los Banos (24 percent correlation with Panoche), and the NCDC station in Madera (10 percent correlation with Panoche) (California Department of Water Resources, accessed June 18, 2002). Precipitation measurements are not recorded at the CIMIS station in Firebaugh. $E T_{0}$ values used for each day from June 6, 1982, through December 31, 2000, were from the CIMIS station in Panoche, if available, followed by the $E T_{0}$ values from the CIMIS station in Firebaugh (96 percent correlation with Panoche), the CIMIS station in Five Points (86 percent correlation with Panoche) (California Department of Water Resources, accessed June 18, 2002), and that estimated from the daily maximum air temperature. The daily maximum air temperature value for the CIMIS station in Panoche was used, if available, followed by the CIMIS station in Firebaugh, the CIMIS station in Five Points, the NCDC weather station at Five Points, the NCDC weather station at Los Banos, and the NCDC weather station at Madera (California Department of Water Resources, accessed June 18, 2002).

\section{Data-Collection Areas}

The study area was divided into 29 contiguous areas for data collection (fig. 3, table 1). However, because of difficulties disaggregating crop acreage and surface-water delivery data, these were consolidated into 11 areas for water-budget calculations. The boundaries of many data-collection areas correspond to those of the irrigation districts, water districts, or other administrative districts. Some district boundaries extend beyond the study area; in these cases, the datacollection area corresponds to the portion of the district that lies within the study area.

The CCID, the San Luis WD, and the Westlands WD, large districts that are only partly within the study area, are each represented by multiple data-collection areas (fig. 3, table 1). The CCID and the San Luis WD are not contiguous within the study area and therefore are each represented by multiple data-collection areas. Approximately one-third of the area of the Westlands WD lies within the study area. Although this is a contiguous area, it was divided into four data-collection areas on the basis of internal administrative divisions and the depth to the water table. The Westlands WD is divided into three administrative areas with differing water rights. The Priority I area, the original Westlands WD, was divided into two data-collection areas for this study: Westlands-IS (Priority I with a shallow water table [less than $10 \mathrm{ft}$ below the land surface]) and Westlands-ID (Priority I with a deeper water table). The Westlands-II data-collection area represents the Westlands WD Priority II area, originally the Westplains Water District. The Westlands-III data-collection area represents the Westlands WD Priority III area, which does not have rights to surface water.

Several data-collection areas represent private land holdings that are not within any incorporated water district. The "Sagouspe" area (site 19 in figure 3), located between the Widren WD and the Mercy Springs WD, represents 1,340 acres of private land holdings. The "Other Areas" area (site 16 in figure 3) represents 2,603 acres, consisting of several contiguous private land holdings, located north of the Pacheco WD. The "No District" area (site 14 in figure 3) represents 1,240 acres of contiguous private land holdings located in the vicinity of the city of Mendota. The "Natural" area (site 13 in figure 3) represents 800 acres of unfarmed land along the Fresno Slough and Mendota Pool.

\section{Crop Acreages}

Annual crop acreages within the study area were compiled for the water years 1972 through 2000 (Appendix A). This information was obtained from a variety of sources. The Grassland Drainers group and several irrigation districts supplied data for specific areas (David Cone, Broadview Water District, written commun., 1999; Joseph McGahan, Summers Engineering, written commun., 2001; Chris White, Central California Irrigation District, written commun., 2001; Sergeant Green, Tranquility Irrigation District, written commun., 2001; James Mallyon, James Irrigation District, written commun., 2001). Crops and crop acreages for the Mendota WMA were provided by the refuge manager, Robert Huddleston (written commun., 2001).

For much of the study area, detailed cropping information was unavailable for most years. However, districts that receive Federal surface water file an annual report with the USBR estimating crop acreages for the coming year (U.S. Bureau of Reclamation, 1970-2000). These reports are planning documents, so there is no assurance that they represent the actual acreages planted; however, these reports are the best available information for most years regarding crop acreages in the study area. Crop acreages for farmed areas that were not part of an organized irrigation district were assumed to be the same as those of an adjacent district. Some missing data were estimated using information supplied by Nigel Quinn (Lawrence Berkeley Laboratory, written commun., 2001) and from Templin and others (1994) and the Irrigation Training and Research Center (1994). When reported acreages for perennial crops fluctuated significantly between years, the acreages were adjusted based on the assumption that perennial crop acreages remain fairly stable from year to year.

\section{Water Deliveries}

Monthly water deliveries within the study area were compiled for water years 1972 through 2000 (Appendix B). Water applied to the land surface in each area generally is surface water imported to the area, ground water pumped within the area, and agricultural runoff and drain water recycled within the area. Public records, including annual delivery reports published by the California Department of Water Resouces (DWR) and the USBR, provide reliable estimates of monthly imports of surface water to each area from 
public water conveyances. These reports, however, may not provide a complete accounting of all surface-water deliveries, as some transfers of surface water may occur outside these public water conveyances. The Irrigation Training and Research Center (1994) found that water delivery records from the DMC and the SLC did not correlate to the records of the districts receiving these deliveries. There are no statutes or regulations requiring that ground-water pumpage by growers in the study area be reported, and thus little data exist regarding the timing or rates of ground-water pumping. There also is little data available regarding district-level recycling of agricultural drain water (tile water) prior to 1995 , and there is little data regarding the volumes of agricultural drain water (tail water) recycled on farms.

\section{Surface-Water Deliveries}

Conveyances used to deliver surface water to the study area include the DMC, SLC, Mendota Pool, San Joaquin River, Fresno Slough, and Kings River. Several districts supplement surface-water allocations from public conveyances with water derived from other sources. These other sources can include ground water pumped into distribution canals from district-owned or grower-owned wells, recycled runoff from on-farm irrigations, and recycled drain water from drainage sumps (tile water).

Monthly surface-water deliveries to each data-collection area between October 1971 and September 2000 (Appendix $B$ ) were compiled from a variety of sources. Monthly deliveries to many districts were available from DWR annual reports of operation (California Department of Water Resources, 1970-2000) and from the financial records database maintained by the USBR (James Cornwell, written commun., 2001). Monthly irrigation deliveries from the SLC by turnout (delivery point) were provided by the DWR (David Duval and Carmen Borelli, written communs., 2001). Estimates of annual deliveries to the Mendota WMA were provided by the refuge manager, Robert Huddleston (written commun., 2001). Monthly deliveries from the Kings River were provided by the Kings River Water Association (Timothy O'Halloran, written commun., 2002). Additional delivery information was provided by Summers Engineering (Joseph McGahan, written commun., 2001), the Broadview Water District (written commun., 1999, and David Cone, written commun., 2002), the Central California Irrigation District (Chris White, written commun., 2001), the James Irrigation District (James Mallyon, written commun., 2001), the Tranquility Irrigation District (Sergeant Green, written commun., 2001), and the Westlands Water District (Thad Bettner, written commun., 2001).

Areal distributions of surface-water deliveries were not available for the districts that were either divided into two or more areas or that are only partly within the study area (table 1). Turnout-level delivery information for the SLC was used to allocate monthly surface-water deliveries to datacollection areas within the San Luis WD and the Westlands WD based on actual delivery information and on the West- lands WD distribution system map (Westlands Water District, 2001). Annual average deliveries to the CCID-Camp 13 area and field-level deliveries to the CCID-NW and CCID-SE areas for 1995 through 1999, provided by the CCID (Chris White, written commun., 2001), were used to estimate surface-water deliveries to these data-collection areas throughout the study period. The CCID also provided estimates of their deliveries to the Other Areas and Duck Club data-collection areas, which receive surface-water deliveries from CCID (Chris White, written commun., 2001). Area-weighted averages were used to allocate surface-water deliveries to the remaining districts. The averages were based on the assumption that each cropped acre within the district received the same amount of water.

Limited data are available on the quantities and timing of surface-water transfers. For this study, district-level and turnout-level delivery data were assumed to include all surface-water deliveries from all sources. This may introduce some error in cases where direct surface-water transfers occur between districts. These transfers occur most often between those districts that are jointly managed, such as the Panoche WD, the Eagle Field WD, the Oro Loma WD, and the Mercy Springs WD. Transfers may also occur in cases where an individual grower owns land in more than one of the data-collection areas. The limited data regarding surface-water transfers supported the need to aggregate geographically contiguous or jointly managed data-collection areas into a water-budget area.

\section{Ground-Water Pumpage}

Growers in some of the data-collection areas, including the Widren WD, Sagouspe, No District, and Westlands-III, do not have firm surface-water delivery contracts and therefore rely heavily on ground water to meet crop demands. Significant operation of grower-owned wells is also believed to have occurred throughout the study period in the Panoche WD, the Pacheco WD, the San Luis WD, and the Westlands WD. Growers also pump ground water for transfer outside their district (San Luis and Delta-Mendota Water Authority, 1995). All available data on ground-water pumpage was added to the water deliveries database, including pumpage by districts and pumpage by growers that was exported from their district.

Accurate information on the location of grower-owned ground-water pumps is difficult to obtain. There is no statute or regulation requiring growers in the study area to meter or limit ground-water pumping. Many growers may not have installed flow meters on their pumps; pump metering was not a common practice before the drought of the early 1990s. The Irrigation Training and Research Center (1994) found that few of the grower-owned wells in Panoche DD had meters. Those growers who do have pumping records often are reluctant to release them because of concerns about both competition and potential regulation. Canessa and Smith (1992) determined that estimates of ground-water pumpage based solely on electricity usage data from a single pump are highly inaccurate, and, on average, differed from flow-meter measurements by 49 percent. Estimates of regional ground-water pumpage that 
are based on electricity usage data are very unreliable because they incorporate additional assumptions regarding the average efficiency of pumping plants, the average depth to ground water, the average operating pressure (a function of the type of irrigation system being used), and the proportion of pumping wells powered with electricity.

\section{Reuse of Irrigation and Drain Water}

Little reliable information is available regarding the amount of tail water that was recycled by districts during the study period, especially between 1972 and 1995. Districts historically have not measured the amounts of drainage water recycled by transferring drainage water from district drainage canals into district irrigation distribution canals, but a limited amount of data are available for some districts beginning in 1990 (Irrigation Training and Research Center, 1994; Joseph McGahan, Summers Engineering, written commun., 2001). Some data are available for the Broadview WD quantifying on-farm recycling of tail water (David Cone, Broadview Water District, written commun., 2002), but only limited data (beginning in 1998) are available for the other districts (Joseph McGahan, Summers Engineering, written commun., 2001). Available data on recycled water were added to the water deliveries database.

\section{Consumption-Distribution Ratio}

Water-balance estimates require knowledge of the relationship between the amount of irrigation water evapotranspired by crops and the amount of irrigation water delivered for each water-budget area. Only a portion of the water delivered to a district is evapotranspired by crops, with the remainder being lost to district and on-farm conveyance losses and becoming recharge. These losses include seepage and spillage from district and farm distribution systems, runoff from farm fields, and percolation below the crop root zone. Common definitions of irrigation efficiency generally ignore distribution losses and include a portion of recharge, the leaching fraction, as a beneficial use. Thus the term irrigation efficiency, as usually defined, is not suitable for quantifying the portion of irrigation water entering a district that becomes recharge. For this study, the consumption-distribution ratio $R$ is used in lieu of irrigation efficiency. $R$ is defined as that portion of irrigation water imported into the irrigation district that is evapotranspired by crops:

$$
R_{s}=U_{s} /\left(S_{s}+G_{s}\right),
$$

where $U_{s}$ is the amount of water evapotranspired by crops in area $s$ after the utilization of effective precipitation, $S_{s}$ is the amount of surface water imported into area $s$, and $G_{s}$ is the amount of ground water applied within area $s$. In this study, a single aggregate, time-invariant $R$ value is used for each waterbudget area.

Gronberg and Belitz (1992) found an inverse relationship between irrigation efficiency and depth to the water table and determined an irrigation efficiency for each water-budget area. The irrigation efficiencies of Gronberg and Belitz (1992) were used in this study, but were re-named "consumptiondistribution ratios" to reflect that they represent the portion of irrigation water deliveries evapotranspired by crops (table 2). $R$ is expected to vary in time, reflecting improvements in irrigation application technologies, increased use of tail-water return systems and district-level recycling of drainage water, and changes in the cost and availability of water. $R$ is also expected to vary depending on the crop and irrigation application technology. Owing to a lack of data regarding long-term changes in $R$, a single time-invariant $R$ was used for each water-budget area.

\section{Canal Seepage}

Canal seepage may be a significant source of recharge for some areas. Canals contributing seepage water include districtlevel and on-farm conveyances and several large conveyances that pass through the study area. Seepage from district-level and on-farm canals was incorporated in $R$ above. Two large surface-water conveyances cross the study area: the SLC and the DMC. The Mendota Pool, another large surface-water conveyance, is adjacent to the southern part of the eastern boundary of the study area (fig. 1). The entire portion of the SLC within the study area and the portion of the DMC north of Eagle Field Road were constructed with a concrete lining. The final $18 \mathrm{mi}$ of the DMC was constructed with lining of compacted earth, and the Mendota Pool is unlined.

A recent USBR study estimated that seepage rates in the SLC are between 29 to 290 (acre-ft/yr)/mi (Turner, 2002). A seepage loss study on the portion of the DMC constructed with a compacted-earth lining, conducted by the USBR shortly after the canal was completed, estimated seepage losses of 43 (acre-ft/yr)/mi (U.S. Bureau of Reclamation, 1953); these rates probably have increased as the canal has aged. A seepage loss estimate for the 14-mile-long Mendota Pool of $60 \mathrm{ft}^{3} / \mathrm{s}$ was provided by the CCID (Chris White, written commun., 2002); this is equivalent to a rate of approximately 3,100 (acre-ft/yr)/mi.

\section{Daily Crop Soil-Moisture Budgets}

Estimates of annual crop water demand were required to estimate recharge to the water table and annual demand for ground water. A soil-moisture budget was used to calculate total crop water demand, the portion of crop water demand met with precipitation, and recharge from precipitation for each water year. A daily soil-moisture budget was developed for each of 66 crops grown in the study area from January 1, 1970, through September 30, 2000 (Appendix C). The crop soil-moisture budget incorporates a daily soil surface processes model, a daily crop consumptive use model, and a daily crop soil-moisture budget model. The soil surface processes model estimates the portion of daily precipitation that enters the soil profile. The crop consumptive-use model calculates crop water demand from the daily reference evapotranspiration. The crop soil-moisture budgets keep track of available 
soil moisture, apply daily infiltration and residual soil moisture to meet crop water demand, and compile annual values of total crop water demand, crop water demand not satisfied with precipitation, and precipitation-derived recharge to the water table for each crop. These values are multiplied by crop acreages for each water-budget area to determine annual demand for irrigation water, which is then used as input to the waterbudget model.

\section{Daily Soil Surface Process Model}

For each day that precipitation occurred, a soil surface process model was used to determine the portion of the precipitation that infiltrated through the soil surface and was available to meet crop water needs. Estimated runoff for each day that precipitation occurred was determined using the runoff curve method of the U.S. Department of Agriculture Soil Conservation Service (1970). A lumped water budget was used for this study because of the lack of spatially distributed crop data; a single, aggregate soil type, therefore, was assumed to apply for the entire study area. Approximate areas of different soils were tabulated from soil maps (U.S. Department of Agriculture Soil Conservation Service, 1912, 1990; U.S. Department of Agriculture Natural Resources Conservation Service 1999 and 2003). Area-weighted aggregate runoff curve numbers for antecedent soil-moisture condition II were then determined for the dormant season (October 1-February 28) and the growing season (March 1-September 30) for the entire study area (U.S. Department of Agriculture Soil Conservation Service, 1990). Corresponding curve numbers for antecedent soil-moisture conditions I and III were determined using adjustment factors (U.S. Department of Agriculture Soil Conservation Service, 1972). The area-weighted dormant-season curve numbers are 80, 91, and 97 for antecedent soil-moisture conditions I, II and III, respectively. The corresponding area-weighted growingseason curve numbers are 53, 75, and 94.

The runoff rate for each day in which precipitation was recorded was determined using the curve number corresponding to the season and the antecedent soil moisture condition (determined from the total precipitation over the previous 5 days). Evaporation of precipitation from the soil surface was handled separately from the crop soil-moisture budgets because most of the precipitation falls in months when few crops are grown. A crop coefficient of 1.0 was assumed to apply, and evaporation of precipitation from the soil surface thus was assumed to equal the potential evapotranspiration rate for the day on which precipitation occurred. Runoff and evaporation of precipitation from the soil surface were subtracted from the daily precipitation, and the remainder was assumed to infiltrate through the soil surface and to be available for plant use.

$$
I_{i}=\left\{\begin{array}{rr}
P_{i}-O_{P}-E T_{o, i} & , P_{i}-O_{P}>E T_{o, i} \\
0 & , P_{i}-O_{P}<E T_{o, i}
\end{array}\right.
$$

where $I_{i}$ is the amount of water infiltrating through the soil surface in day $i, P_{i}$ is the amount of precipitation on day $i$, and $O_{p}$ is the amount of runoff for precipitation rate $P_{i}$. Daily $E T_{0}$ also was reduced by the amount of energy required to evaporate precipitation from the soil surface. Bare-soil evaporation for days on which no precipitation occurred was incorporated into the consumption-distribution ratio $R$.

\section{Daily Crop Water Demand Model}

Daily crop water demand was defined for this study as daily crop evapotranspiration $\left(E T_{c}\right) . E T_{c}$ was estimated as the product of $E T_{O}$ and the daily crop coefficient $\left(K_{c}\right)$ :

$$
E T_{c}=E T_{0} \times K_{c}
$$

The California Irrigation Management Information System (CIMIS) estimates $E T_{0}$ as the daily evapotranspiration of a reference crop of well-irrigated grass. Crop coefficients express the relationship between this reference evapotranspiration and evapotranspiration from the crop of interest. The crop coefficient varies daily; it is based on the growth stage of the plant and the plant characteristics including leaf area, stomata behavior, plant height, solar radiation reflected from leaves, and aerodynamic properties (Hanson and others, 1999). This approach estimates the maximum crop water demand, assuming water is never a limiting factor. Daily $E T_{c}$ for each crop is assumed to be constant over the entire study area, ignoring any differences due to soils, planting dates, and irrigation techniques.

Crop water demand can be roughly related to the crop growth stage. The crop coefficients used in this study were based on an idealized crop growth curve. This growth curve was divided into four stages: the initial growth stage, the rapid growth stage, the mid-season stage, and the late-season stage (fig. 5). Crop coefficients were modeled by assigning growth dates and $K_{c}$ values to transition points between these stages and by assuming a linear change in the $K_{c}$ value throughout each stage. Thus, the $K_{c}$ values for each crop were tabulated using five growth dates (A, B, C, D and E) and four crop coefficients $\left(K_{c 0}, K_{c 1}, K_{c 2}\right.$ and $\left.K_{c 3}\right)$. These tabulated crop coefficient values were used to construct a piecewise linear function to determine the crop coefficient for any given day for each crop.

Five-point $K_{c}$ curves were tabulated for 66 crops grown in the study area (table 3 ). The wildlife management area is considered a crop for the purposes of this study because it is irrigated. Crop $K_{c}$ values were derived from several sources. When available, published crop coefficients for the western San Joaquin Valley were used; when no published crop coefficients were available for the San Joaquin Valley, published crop coefficients for another climate were adjusted to reflect the climate of the western San Joaquin Valley. 


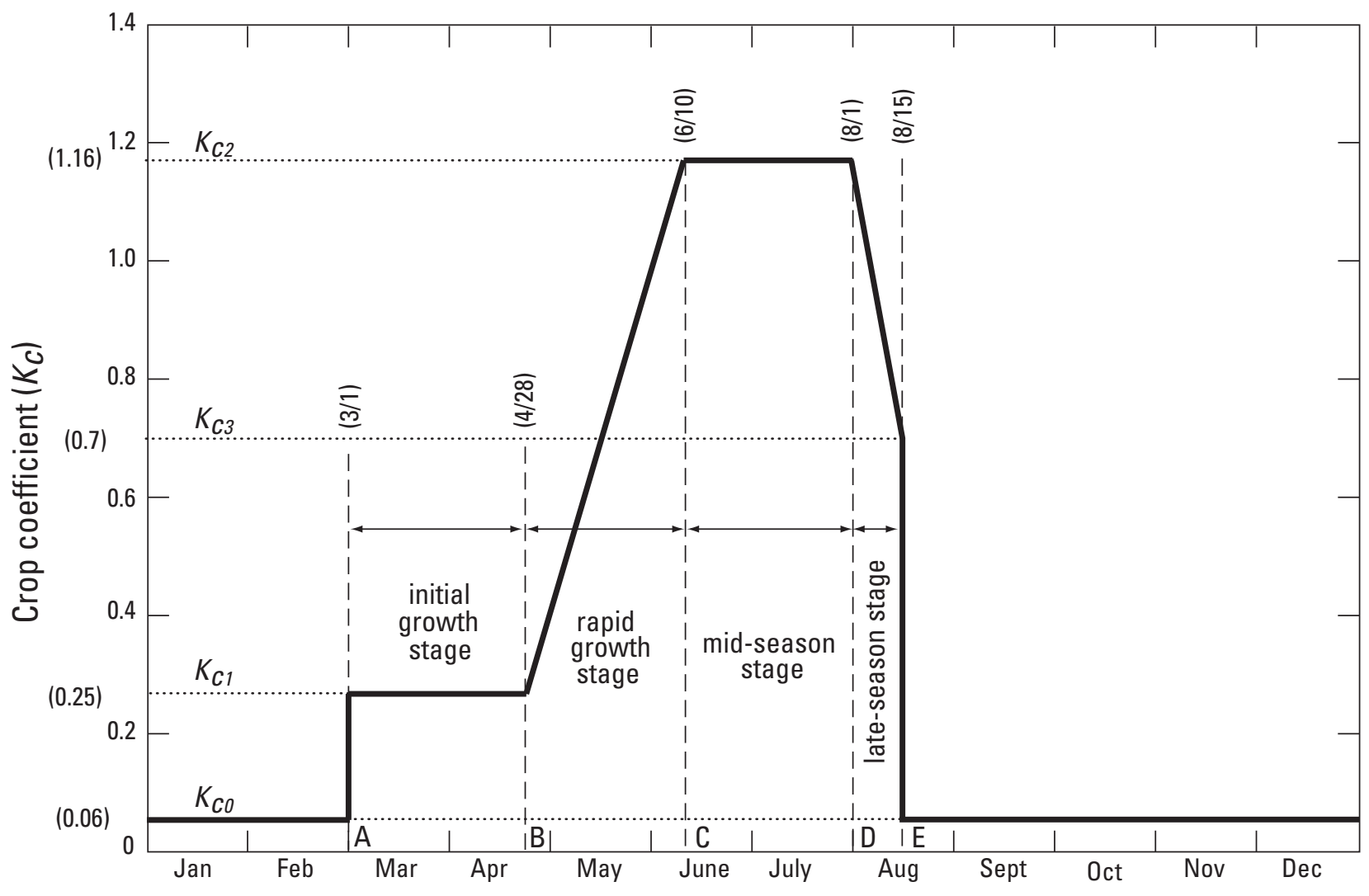

Month

Figure 5. Idealized crop coefficient $\left(K_{c}\right)$ curve expressing the relationship between reference evapotranspiration rate $\left(E T_{0}\right)$ and the evapotranspiration rate for a particular crop $\left(E T_{c}\right)$. The specific growth dates (A, B, C, D and E) and crop coefficients $\left(K_{c 0^{\prime}} K_{c \nu^{\prime}} K_{c 2^{\prime}} K_{c 3^{3}}\right)$ for each crop vary depending on the planting date and climatic zone. 
Table 3. Crop coefficients and rooting depths for vegetation types in the central part of the western San Joaquin Valley, California.

$\left[K_{c}\right.$, crop coefficient. Source: 1, Allen and others, 1998; 2, Snyder and others, 1987a; 3, Snyder and others, 1987b; 4, Irrigation Training and Research Center, 1994; 5, Hanson and others, 1999; 6, Center for Irrigation Technology, California State University, Fresno accessed June 18, 2002; 7, Center for Agroecology and Sustainable Food Systems, University of California, Santa Cruz, accessed December 23, 2003; 8, California Avocado Commission, accessed June 18, 2002]

\begin{tabular}{|c|c|c|c|c|c|c|c|c|c|c|c|c|}
\hline \multirow[b]{2}{*}{ Crop } & \multicolumn{4}{|c|}{ Crop coefficients } & \multicolumn{5}{|c|}{ Growth dates } & \multirow{2}{*}{ Source } & \multirow{2}{*}{$\begin{array}{c}\text { Rooting } \\
\text { depth(feet } \\
\text { below land } \\
\text { surface) }\end{array}$} & \multirow[b]{2}{*}{ Source } \\
\hline & $K_{c 0}$ & $K_{c l}$ & $\boldsymbol{K}_{c 2}$ & $\boldsymbol{K}_{c 3}$ & $\mathbf{A}$ & B & C & D & $\mathbf{E}$ & & & \\
\hline Cotton & 0.00 & 0.16 & 1.18 & 0.40 & $4 / 17$ & $5 / 19$ & $7 / 7$ & $9 / 21$ & $10 / 16$ & 2 & 4 & 5 \\
\hline Tomatoes & .00 & .24 & 1.12 & .70 & $4 / 2$ & $5 / 9$ & $6 / 29$ & $8 / 24$ & $9 / 1$ & 2 & 3 & 5 \\
\hline Alfalfa $^{1}$ & .40 & .40 & 1.20 & .40 & $1 / 1$ & $2 / 3$ & $3 / 21$ & $8 / 10$ & $9 / 22$ & 2 & 5 & 5 \\
\hline Alfalfa seed & .00 & .70 & 1.05 & .34 & $3 / 1$ & $4 / 12$ & $5 / 24$ & $8 / 16$ & $8 / 31$ & $\left({ }^{2}\right)$ & 3 & $\left(^{2}\right)$ \\
\hline Beans & .00 & .14 & 1.12 & .35 & $5 / 2$ & $5 / 19$ & $6 / 9$ & $7 / 30$ & $8 / 16$ & 2 & 2 & 5 \\
\hline Corn & .00 & .18 & 1.10 & .45 & $4 / 17$ & $5 / 8$ & $6 / 29$ & $8 / 28$ & $9 / 16$ & 2 & 3 & 5 \\
\hline Corn nuts & .00 & .14 & 1.10 & .10 & $2 / 16$ & $4 / 1$ & $5 / 1$ & $6 / 28$ & $7 / 1$ & 2 & 3 & 5 \\
\hline Melons & .00 & .18 & 1.11 & .08 & $3 / 17$ & $4 / 18$ & $5 / 24$ & $7 / 29$ & $8 / 1$ & 2 & 3 & 5 \\
\hline Onions & .00 & .30 & 1.14 & .63 & $3 / 2$ & $4 / 12$ & $5 / 25$ & $8 / 5$ & $9 / 1$ & 2 & 1 & 5 \\
\hline Garlic $^{3}$ & .00 & .18 & 1.15 & .78 & $9 / 17$ & $10 / 7$ & $1 / 2$ & $4 / 10$ & $6 / 1$ & 2 & 1 & 5 \\
\hline Seed onion & .06 & .70 & 1.05 & .30 & $3 / 2$ & $4 / 12$ & $5 / 25$ & $8 / 16$ & $9 / 1$ & $\left({ }^{2}\right)$ & 1 & $\left({ }^{2}\right)$ \\
\hline Potatoes & .00 & .43 & 1.18 & .40 & $2 / 2$ & $3 / 1$ & $4 / 13$ & $6 / 10$ & $6 / 16$ & 2 & 3 & 5 \\
\hline Rice & .00 & .95 & 1.25 & .95 & $4 / 2$ & $4 / 27$ & $5 / 29$ & $7 / 25$ & $9 / 1$ & 2 & 1 & $\left({ }^{2}\right)$ \\
\hline Small grains $^{3}$ & .00 & .25 & 1.20 & .40 & $11 / 2$ & $12 / 15$ & $1 / 26$ & $5 / 8$ & $5 / 16$ & 2 & 3 & 5 \\
\hline Barley $^{3}$ & .00 & .22 & 1.17 & .38 & $12 / 2$ & $12 / 15$ & $3 / 3$ & $4 / 29$ & $6 / 1$ & 2 & 3 & 5 \\
\hline Wheat $^{3}$ & .00 & .23 & 1.18 & .18 & $12 / 17$ & $1 / 21$ & $3 / 17$ & $6 / 15$ & $7 / 1$ & 2 & 3 & 5 \\
\hline Oat hay & .00 & .30 & 1.17 & .20 & $1 / 1$ & $2 / 2$ & $3 / 23$ & $6 / 28$ & $7 / 1$ & 2 & 2 & 5 \\
\hline $\begin{array}{l}\text { Sorghum } \\
\text { (grain) }\end{array}$ & .00 & .14 & 1.08 & .30 & $6 / 17$ & $7 / 13$ & $8 / 11$ & $10 / 7$ & $11 / 1$ & 2 & 3 & 5 \\
\hline Sugar beets & .00 & .15 & 1.11 & .95 & $3 / 17$ & $4 / 11$ & $6 / 8$ & 9/9 & $9 / 16$ & 2 & 2 & 5 \\
\hline Red beets & .00 & .23 & 1.10 & .95 & $6 / 17$ & $7 / 7$ & $8 / 14$ & $8 / 13$ & $8 / 16$ & 2 & 2 & 5 \\
\hline Pasture & .06 & .90 & .90 & .90 & $1 / 1$ & $1 / 3$ & $5 / 2$ & $12 / 29$ & $12 / 31$ & 2 & 2 & 5 \\
\hline Clover & .06 & 1.05 & 1.05 & 1.05 & $1 / 1$ & $1 / 3$ & $1 / 4$ & $12 / 29$ & $12 / 31$ & 2 & 2 & 5 \\
\hline Apples & .06 & .52 & .97 & .85 & $2 / 16$ & $3 / 2$ & $5 / 29$ & $9 / 20$ & $11 / 1$ & 3 & 3 & 5 \\
\hline Apricots & .06 & .52 & .87 & .65 & $2 / 16$ & $3 / 2$ & $5 / 29$ & $9 / 20$ & $11 / 1$ & 3 & 4 & 5 \\
\hline Cherries & .06 & .52 & .97 & .85 & $2 / 16$ & $3 / 2$ & $5 / 29$ & $9 / 20$ & $11 / 1$ & 3 & 4 & 5 \\
\hline Nectarines & .06 & .52 & .87 & .65 & $2 / 16$ & $3 / 2$ & $5 / 29$ & $9 / 20$ & $11 / 1$ & 3 & 4 & 5 \\
\hline Peaches & .06 & .52 & .87 & .65 & $2 / 16$ & $3 / 2$ & $5 / 29$ & $9 / 20$ & $11 / 1$ & 3 & 4 & 5 \\
\hline Plums & .06 & .52 & .87 & .65 & $2 / 16$ & $3 / 2$ & $5 / 29$ & $9 / 20$ & $11 / 1$ & 3 & 4 & 5 \\
\hline Prunes & .06 & .52 & .87 & .65 & $2 / 16$ & $3 / 2$ & $5 / 29$ & $9 / 20$ & $11 / 1$ & 3 & 4 & 5 \\
\hline Grapefruit & .65 & .65 & .65 & .65 & $1 / 1$ & $1 / 3$ & $5 / 2$ & $10 / 2$ & $12 / 31$ & 6 & 2 & 7 \\
\hline Grapes & .06 & .25 & .80 & .30 & $3 / 2$ & $3 / 17$ & $5 / 31$ & $10 / 16$ & $12 / 31$ & 3 & 3 & 5 \\
\hline Eucalyptus & .06 & .60 & .60 & .60 & $1 / 1$ & $1 / 3$ & $1 / 4$ & $10 / 28$ & $12 / 31$ & $\left({ }^{2}\right)$ & 5 & $\left({ }^{2}\right)$ \\
\hline Artichokes & .06 & .25 & .65 & .65 & $7 / 9$ & $7 / 16$ & $10 / 1$ & $4 / 26$ & $4 / 29$ & 6 & 3 & 5 \\
\hline Asparagus & .00 & .25 & 1.00 & .37 & $1 / 22$ & $2 / 6$ & $5 / 8$ & $11 / 14$ & $12 / 31$ & 6 & 6 & 5 \\
\hline Broccoli & .00 & .30 & 1.00 & .87 & $3 / 22$ & $4 / 2$ & $5 / 16$ & $5 / 15$ & $6 / 29$ & 6 & 2 & 5 \\
\hline Cabbage & .00 & .30 & 1.00 & .87 & $3 / 22$ & $4 / 2$ & $5 / 16$ & $5 / 15$ & $6 / 29$ & 6 & 2 & 5 \\
\hline Carrots & .00 & .85 & .95 & .83 & $1 / 22$ & $2 / 6$ & $3 / 21$ & $5 / 13$ & $5 / 16$ & 6 & 2 & 5 \\
\hline Cauliflower & 0.00 & 0.30 & 1.00 & 0.87 & $3 / 22$ & $4 / 2$ & $5 / 16$ & $5 / 15$ & $6 / 29$ & 6 & 2 & 5 \\
\hline
\end{tabular}


Table 3. Crop coefficients and rooting depths for vegetation types in the central part of the western San Joaquin Valley, California.-Continued

[ $K_{c}$, crop coefficient. Source: 1, Allen and others, 1998; 2, Snyder and others, 1987a; 3, Snyder and others, 1987b; 4, Irrigation Training and Research Center, 1994; 5, Hanson and others, 1999; 6, Center for Irrigation Technology, California State University, Fresno accessed June 18, 2002; 7, Center for Agroecology and Sustainable Food Systems, University of California, Santa Cruz, accessed December 23, 2003; 8, California Avocado Commission, accessed June 18, 2002]

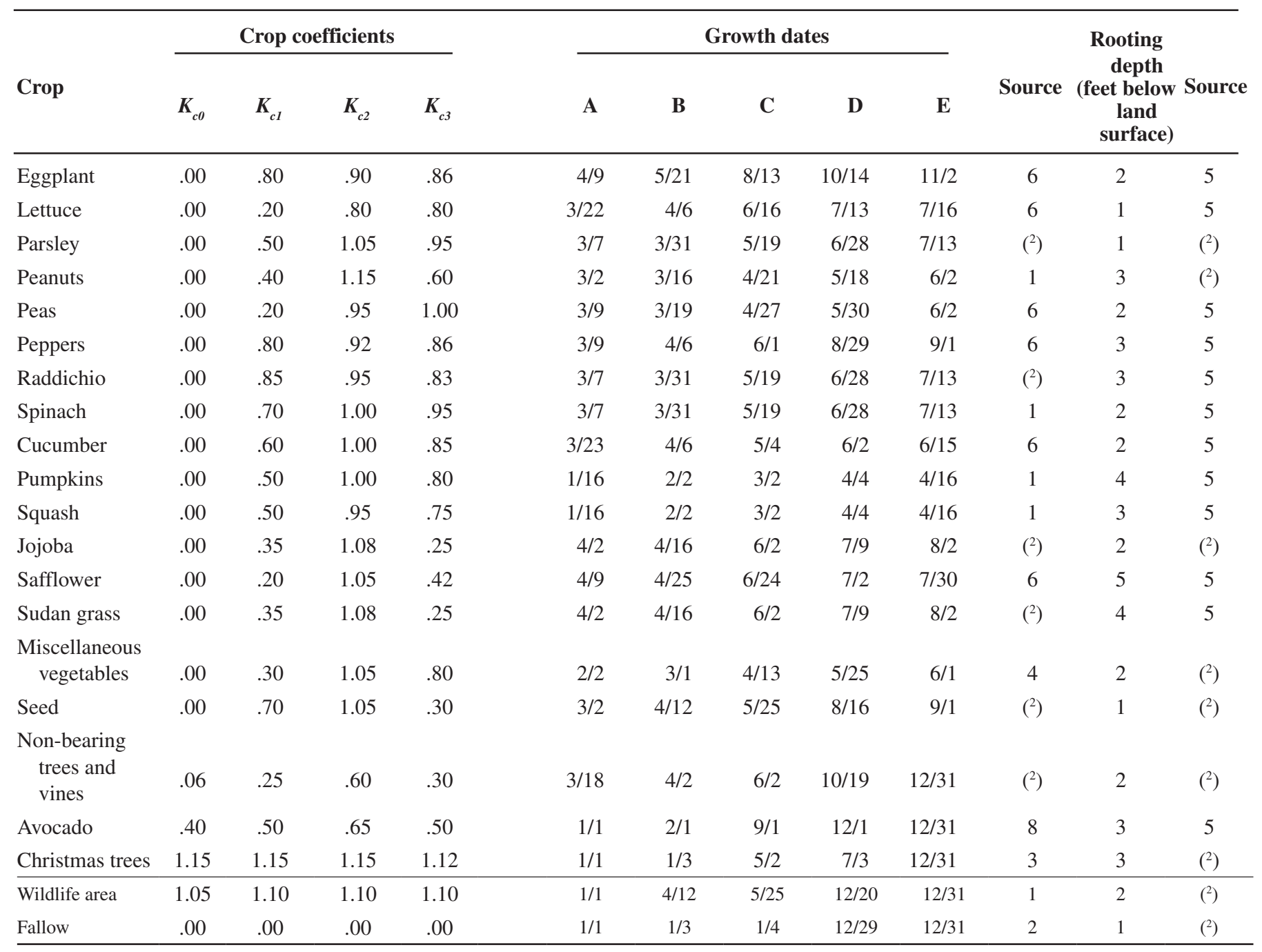

${ }^{1}$ Multiple cuttings

${ }^{2}$ Estimated.

${ }^{3}$ Winter crop. 


\section{Daily Soil-Moisture Budget}

A soil-moisture budget was compiled for each of 66 crops grown in the study area using a simple box model (fig. 6). Inputs to the crop soil-moisture budget included daily $E T_{0}$ and infiltration $\left(I_{i}\right)$. Daily crop water demand for each crop, assuming water was never a limiting factor, was calculated as the product of the daily $E T_{0}$ and the daily $K_{c}$, as described in the Daily Crop Water Demand Model section.

The crop soil-moisture capacity was estimated as the product of the maximum crop rooting depth and an average field capacity of $0.15 \mathrm{in} / \mathrm{in}(0.15 \mathrm{in}$. water per $1 \mathrm{in}$. in soil profile depth) as estimated for the soils in the study area (U.S.
Department of Agriculture, Natural Resources Conservation Service, 2003):

$$
M_{\mathrm{max}, \mathrm{c}}=\theta * L_{\mathrm{c}}
$$

where $\mathrm{M}_{\text {max,c }}$ is the soil-moisture capacity for $\operatorname{crop} c, \theta$ is the average field capacity, and $L_{c}$ is the rooting depth for $\operatorname{crop} c$. The model assumes there are no restrictive, lower permeability layers within or beneath the root zone. The soil hydraulic conductivity is assumed to be high enough for the soil moisture to be uniformly redistributed, and the entire soil column within the root zone to be drained, in a 24-hour period.
$\boldsymbol{A}$

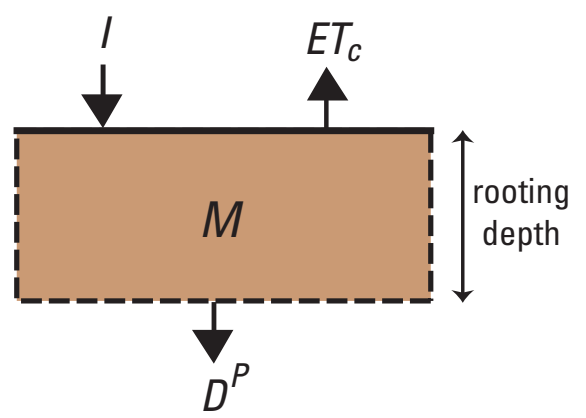

B

\section{$\begin{array}{lllll}\text { crop } 1 & \text { crop } 2 & \text { crop } 3 & \ldots & \text { crop } 70\end{array}$}

day 1

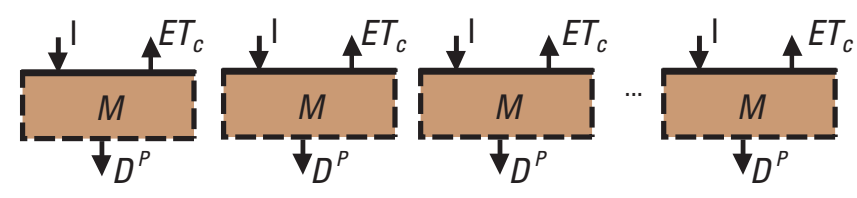

day 2
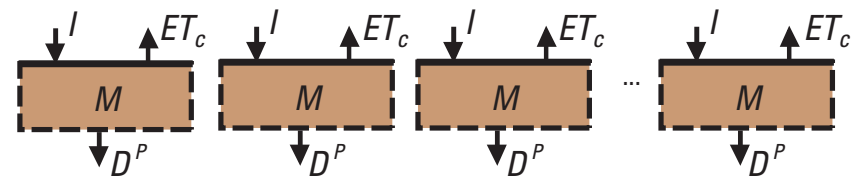

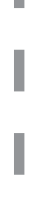

day 3
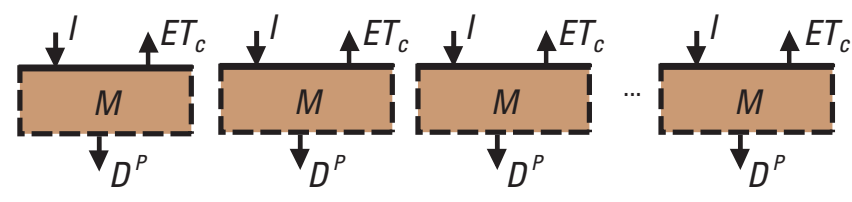

I

day 365
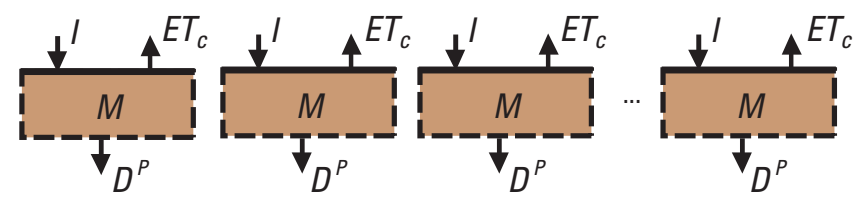

\section{EXPLANATION}

$\begin{array}{cl}E T_{c} & \text { Crop evapotranspiration } \\ D^{P} & \text { Deep percolation from precipitation } \\ M & \text { Soil moisture capacity } \\ I & \text { Infiltration }\end{array}$

Figure 6. Conceptual model of the crop-specific daily soil-moisture budget for vegetation types in the central part of the western San Joaquin Valley, California. A, Single crop, single day. B, Multiple crop, multiple day. 
For each day, effective precipitation was added to initial soil moisture to determine available soil moisture:

$$
M_{i}=M_{o, i}+I_{i},
$$

where $M_{i}$ is the available soil moisture on day $i$, and $M_{o, i}$ is the initial soil moisture on day $i$. Daily $E T_{c}$ then was subtracted from the available soil moisture (if any) to determine the soil moisture at the end of the day:

$$
M_{i}=\left\{\begin{array}{ll}
0 & , E T_{c} \geq M_{i} \\
M_{i}-E T_{c} & , E T_{c}<M_{i} \\
M_{i} & , E T_{c}=0
\end{array} .\right.
$$

If the soil moisture at the end of the day was greater than the soil-moisture capacity of the soil, the excess was assumed to exit as recharge:

$$
D_{c, i}^{p}=\left\{\begin{array}{cc}
M_{i}-M_{\max , c}, & M_{i} \geq M_{\max , c} \\
0 \quad, & M_{i}<M_{\text {max }, c}
\end{array},\right.
$$

where $D_{c, i}^{p}$ is the precipitation component of recharge beneath crop $c$ on day $i$, and any remaining soil moisture was carried over to the next day:

$$
M_{o, i+1}=\left\{\begin{array}{l}
M_{\max , c}, M_{i} \geq M_{\max , c} \\
M_{i}, M_{i}<M_{\max , c}
\end{array} .\right.
$$

The portion of the daily crop water demand that was not satisfied by soil moisture also was calculated for each day:

$$
U_{c, i}=\left\{\begin{array}{ll}
E T_{c}-M_{i} & , E T_{c} \geq M_{i} \\
E T_{c} & , M_{i}=0 \\
0 & , E T_{c}<M_{i}
\end{array},\right.
$$

where $U_{c, i}$ is the the unmet water demand for crop $c$ on day $i$.

Total crop water demand $\left(E T_{c, y}\right)$, unmet crop water demand $\left(U_{c, y}\right)$, and recharge from precipitation $\left(D_{c, i}^{p}\right)$ were calculated for each water year by summing the daily values:

$$
\begin{aligned}
E T_{c, y} & =\sum_{i=1}^{\text {days }} E T_{c, i}, \\
U_{c, y} & =\sum_{i=1}^{\text {days }} U_{c, i},
\end{aligned}
$$

and

$$
D_{c, y}^{p}=\sum_{i=1}^{\text {days }} D_{c, i}^{p}
$$

The values for maximum total crop water demand, maximum unmet crop water demand, and recharge from precipitation for all 66 crops for each water year from 1972 through 2000 were collected in a single file (Appendix $C$ ) and were used as input for the annual water-budget calculations.

\section{Annual Water Budgets}

Water budgets were initially created for each of the 29 data-collection areas. However, the temporal and spatial resolution of the crop acreage and surface-water delivery data were not sufficient to support the water budgets at this scale. Therefore, the 29 data-collection areas were combined into 11 larger areas for water-budget calculations. The soil-moisture budget output for each crop was combined with crop acreage and surface-water delivery data in the water budget to estimate annual recharge and ground-water pumpage. A control volume was defined for each of the 11 water-budget areas. The lateral boundaries of each control volume correspond to administrative boundaries, for example irrigation district boundaries. The upper boundary of each control volume is the land surface and the lower boundary is the bottom of the crop root zone, based on a weighted average of all the crops grown in each waterbudget area.

Unmet crop water demand is the primary factor affecting the ground-water pumpage estimate for each water year. For the purposes of this study, water deliveries were assumed to be equal to the irrigation demand. The estimated ground-water pumpage, therefore, is an estimate of the maximum amount of ground-water pumpage; actual pumpage may be lower if growers chose to under-irrigate or reduce crop acreages rather than pump ground water. 


\section{Water-Budget Model}

Each water-budget area was modeled using a simple box model (fig. 7). For each water year, the unmet crop water demand and the recharge from precipitation for each crop were multiplied by the number of acres of the crop grown in each area to produce inputs for each water-budget area. The amount of irrigation water required to meet crop demand was calculated for each year. The surface-water deliveries to the area were subtracted from the irrigation requirement, and the amount of applied ground water required to satisfy the remaining demand then was calculated using the assumption that water was never a limiting factor. Annual recharge from precipitation, surface water, and ground water also was calculated.

The water-budget model was used to estimate both recharge to the water table and ground-water pumpage by water year for each area. A crop water demand model incorporating the total crop water demand for each water year $\left(U_{c, y}\right)$

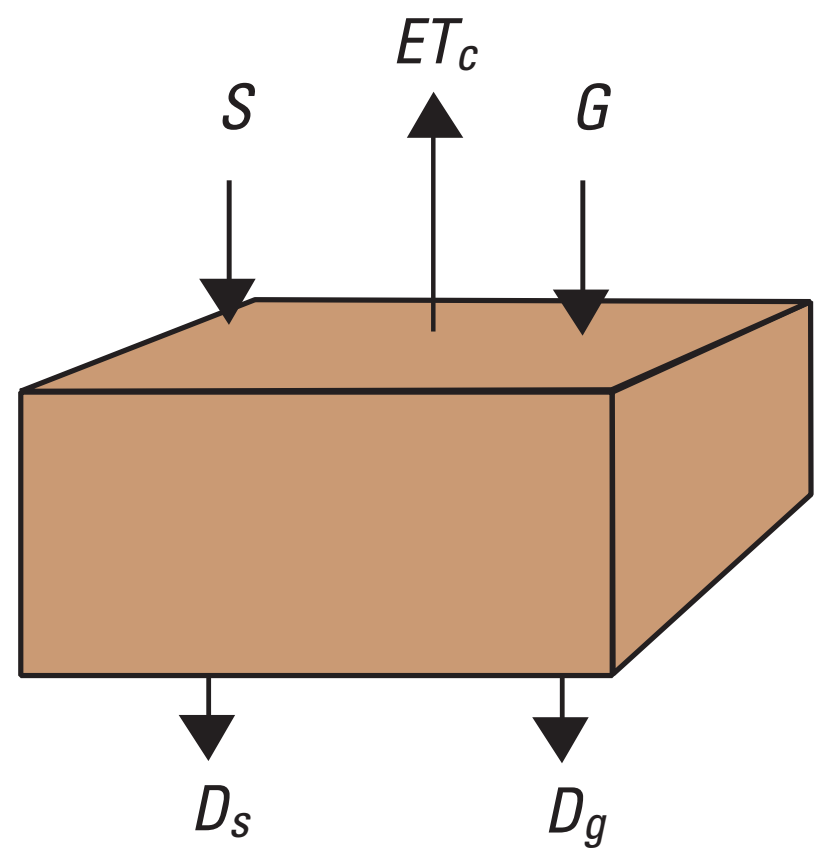

\section{EXPLANATION}

\section{$E T_{c} \quad$ Crop evapotranspiration \\ $S \quad$ Irrigation with surface water \\ G Irrigation with ground water \\ $D_{s} \quad$ Deep percolation from applied surface water \\ $D_{g} \quad$ Deep percolation from applied ground water}

Figure 7. Conceptual model of the annual water balance for each water-budget area in the Grasslands area of the central part of the western San Joaquin Valley, California. and crop acreage data were used to calculate the annual total crop water demand for each water-budget area. Total crop water demand then was divided by the consumptiondistribution ratio $R$ (table 2 ) to determine the annual irrigation demand. Surface-water delivery data were compared with the annual irrigation demand; for areas where pumping occurs, the amount of ground water required to meet any remaining irrigation demand was calculated. Total recharge was also determined by adding recharge from precipitation for each water year $\left(D_{c, y}^{p}\right)$ to recharge from surface water and from ground water. Finally, pumpage and recharge volumes were converted to rates.

Total crop water demand $\left(W_{s, y}\right)$, unmet crop water demand $\left(U_{s, y}\right)$ and recharge from precipitation $\left(D_{s, y}^{p}\right)$ for each water year $(y)$ were summed for each area $(s)$ by combining crop information from the crops database with results of the crop-specific soil-moisture budgets:

$$
W_{s, y}=\sum_{c=1}^{c r o p s} E T_{c, y} A_{c, s, y}
$$

$$
U_{s, y}=\sum_{c=1}^{\text {crops }} U_{c, y} A_{c, s, y}
$$

and

$$
D_{s, y}^{p}=\sum_{j=1}^{\text {crops }} D_{c, y}^{p} A_{c, s, y}
$$

where $A_{c, s, y}$ is the acreage of crop $c$ grown in water-budget area $s$ in year $y$. The total cropped acreage for each water-budget area for each year $\left(A_{s, y}\right)$ also was calculated:

$$
A_{s, y}=\sum_{j=1}^{\text {crops }} A_{c, s, y}
$$

and the total area of the water-budget area, in acres $\left(A_{s, T}\right)$, was retrieved from the crops database.

For each water year, the total irrigation water requirement for each area $\left(U_{s, y}^{\prime}\right)$ was determined by dividing the unmet crop water demand by the $R$ value of the area $\left(R_{s}\right)$ :

$$
U_{s, y}^{\prime}=\frac{U_{s, y}}{R_{s}} .
$$

Data on surface-water imports to each water-budget area for each water year $\left(S_{s, y}\right)$ were retrieved by irrigation district from the water deliveries database. If data on ground-water 
pumping were available, the amount of the ground water used inside the district $\left(G_{s, y}^{D}\right)$ also was retrieved from the database. The total available water $\left(S_{s, y}^{T}\right)$ is the sum of

$$
S_{s, y}^{T}=S_{s, y}+G_{s, y}^{D}
$$

The post-surface-water irrigation deficit $\left(U_{s, y}^{\prime \prime}\right)$ was then calculated:

$$
U_{s, y}^{\prime \prime}=\max \left(U_{s, y}^{\prime}-S_{s, y}^{T}, 0\right)
$$

The amount of ground water that growers would need to pump to meet the remaining crop water demand for each year $\left(G_{s, y}^{G}\right)$ was calculated:

$$
G_{s, y}^{G}=\left\{\begin{array}{ll}
U_{s, y}^{\prime \prime} & , \text { pumping } \\
0 & , \text { no pumping }
\end{array} .\right.
$$

Some growers occasionally pumped ground water to sell to districts and growers outside their district. The amount of this exported ground water ( $G_{s, y}^{E}$ ) was retrieved from the database and included in the total ground water pumped in each area $\left(G_{s, y}^{T}\right)$ :

$$
G_{s, y}^{T}=G_{s, y}^{D}+G_{s, y}^{G}+G_{s, y}^{E}
$$

Total recharge $\left(D_{s, y}^{T}\right)$ was calculated from $D_{s, y}^{p}$ (calculated in the daily model) plus the portion of imported surface water $\left(S_{s, y}\right)$ and applied ground water $\left(G_{s, y}\right)$ that was not used to meet crop water demand:

$$
D_{s, y}^{T}=D_{s, y}^{P}+\max \left(U_{s, y}^{\prime}-\left(S_{s, y}+G_{s, y}\right), 0\right),
$$

\section{Supply-Based Consumptive Use in Broadview}

Inaccuracies in reported crop acreages can introduce errors in the total crop water demand estimate. As an alternative to using reported crop acreages, crop water demand can be calculated using irrigation supply estimates and an assumption that growers reduce crop acreage until crop water demand equals water supply. It was possible to calculate the supplybased crop water demand for the Broadview water-budget area because no ground-water pumping occurs in this area and because surface-water supply data for this area is very accurate. Using this calculation, we were able to compare the supplybased crop water demand estimates and the climate-based crop water demand estimates for the Broadview water-budget area.

\section{Results and Discussion}

Daily climate data were collected for the study area, and annual crop acreage and water delivery data were collected for 29 data-collection areas. Crop soil-moisture budgets were used to estimate annual total crop water demand and unmet demand after utilization of effective precipitation. Annual water budgets, compiled using annual crop water demand and crop acreage and water delivery data, were used to estimate annual ground-water pumpage and recharge rates for 11 water-budget areas for water years 1972 through 2000. The estimates were used to compute annual aggregate crop coefficients, $K_{d}$, for each water-budget area. The sensitivity of the ground-water pumpage and recharge estimates to several input parameters also were investigated.

\section{Data Acquisition}

Daily precipitation data are included in Appendix A. A histogram of daily precipitation in the study area for October 1971 through September 2000 is presented in figure 8. There were only 7 days with 24 -hour precipitation greater than 1.5 in. during this period. The highest 24-hour precipitation during the study period, 2.6 in., occurred on March 10, 1995. The average annual precipitation rate for each decade of the study period increased by approximately $1 \mathrm{in} / \mathrm{yr}$, from $7.9 \mathrm{in} / \mathrm{yr}$ for water years $1972-79$, to $8.8 \mathrm{in} / \mathrm{yr}$ for water years $1980-89$, to $10.1 \mathrm{in} / \mathrm{yr}$ for water years 1990-2000.

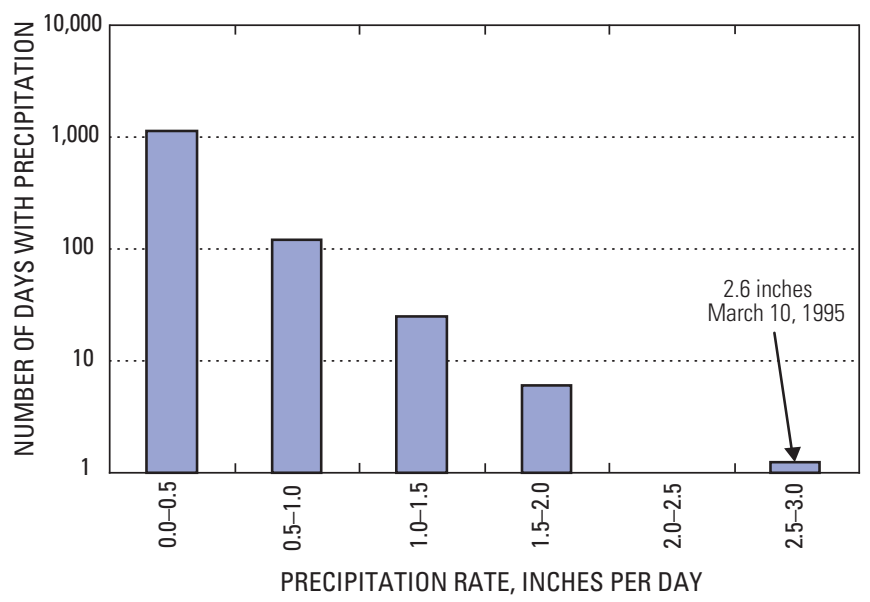

Figure 8. Histogram of 24-hour precipitation for the central part of the western San Joaquin Valley, California, October 1971 to September 2000. 
$E T_{0}$ fluctuated significantly from day to day, as indicated in figure 9. However, the annual total $E T_{0}$ is relatively constant each year. The annual trend in $E T_{0}$ is similar to a trianglular-shaped trend from February 1 to

December 1 , with the apex around July 1 and a relatively constant value during December and January (fig. 9).

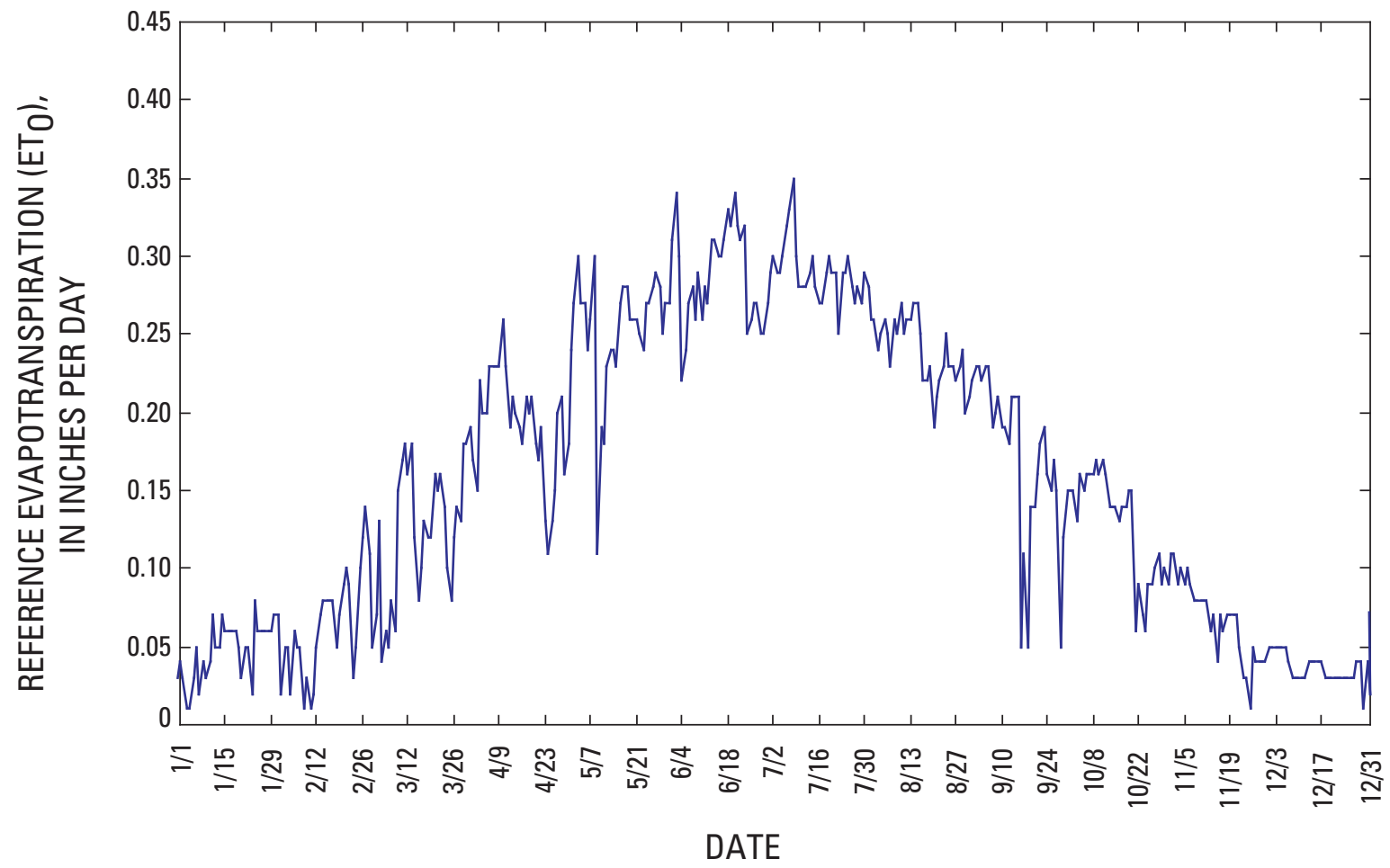

Figure 9. Daily reference evapotranspiration for the central part of the western San Joaquin Valley, California, 1989. 
The percentage of the study area cropped during water years 1972 through 2000 is shown in figure 10. The graph is divided into four periods of surface-water availability that were delineated using the CDM index (fig. 4): a period of growth as deliveries from the SLC increased (1972-78), a period of abundant surface-water supplies (1979-89), a period characterized by drought (1990-93), and a period of reduced supplies (1994-2000). Large fluctuations in crop acreage during the first two periods corresponding to changes in surfacewater supplies contrast with the relatively stable crop acreages in the last two periods (with the exception of 2000) even as surface-water supplies fluctuated.

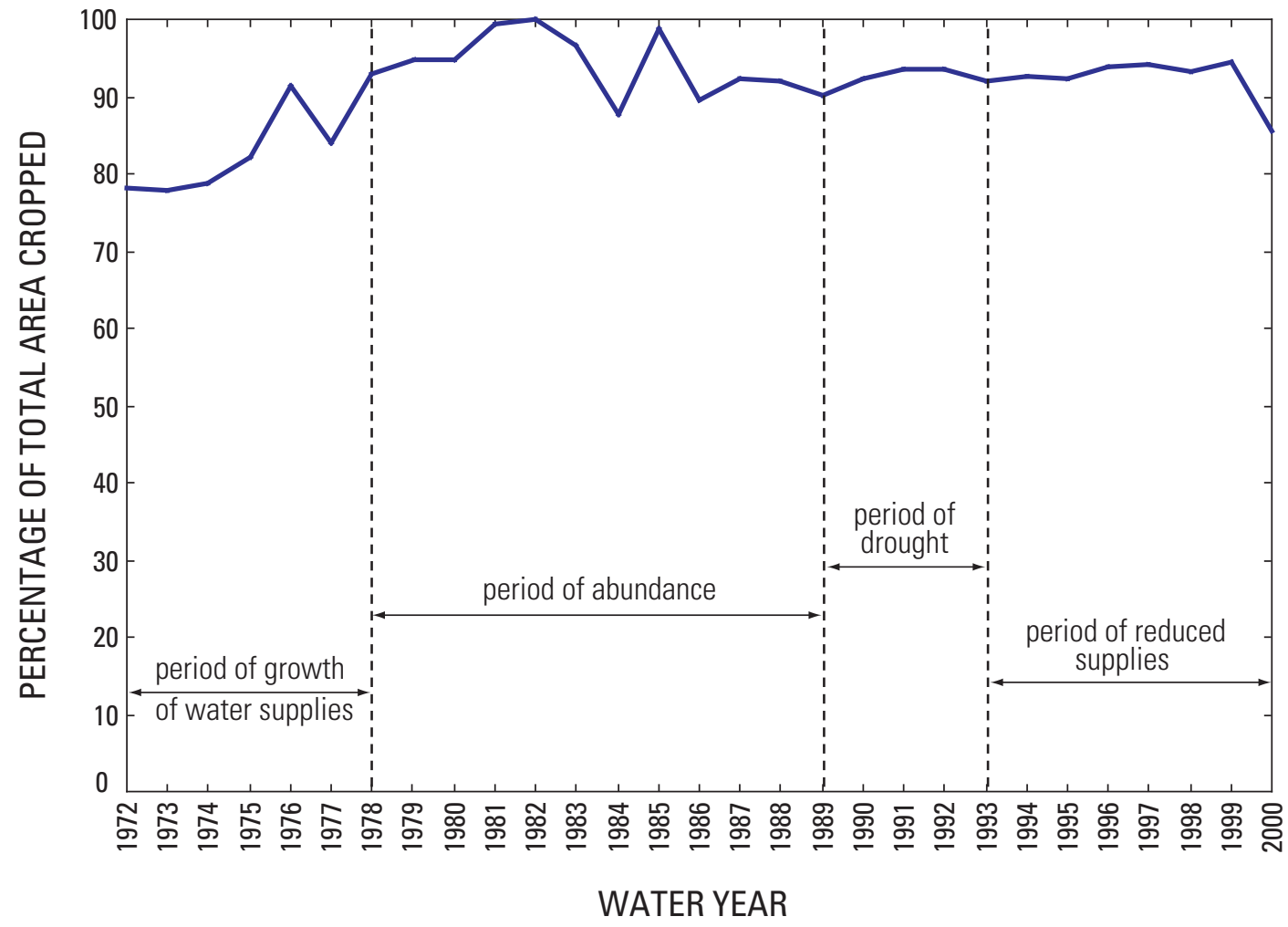

Figure 10. Percentage of the total cropped area planted with crops in the Grasslands area of the central part of the western San Joaquin Valley, California, water years 1972-2000. 
The change through time in the percentage of area cropped in each water-budget area (fig. 11) is strongly related to the availability of irrigation water supplies. Maximum crop acreages remain relatively steady (near the 1972 level) in those areas that receive water primarily from the DMC and the Mendota Pool (fig. 11A). In contrast, crop acreages

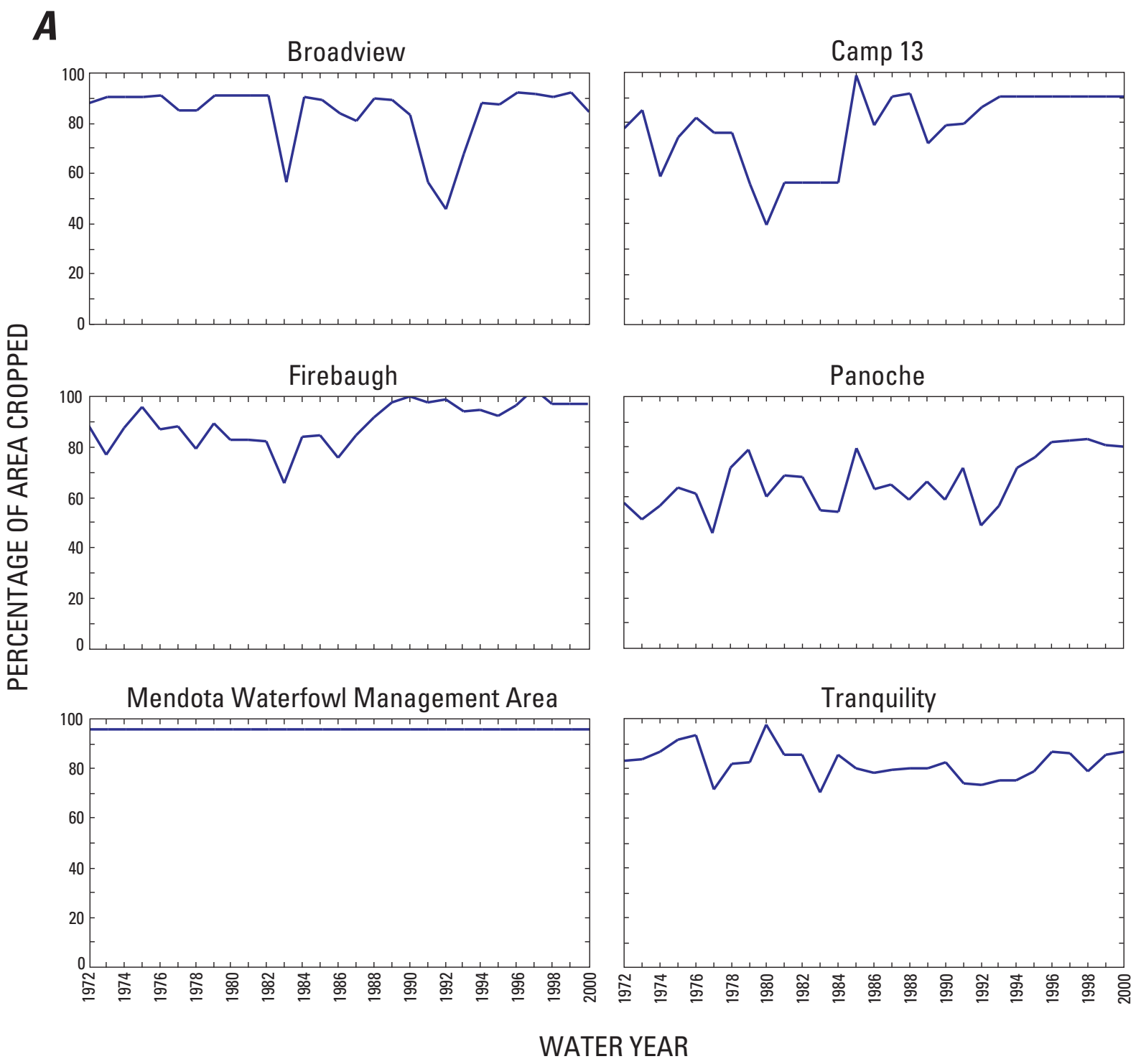

Figure 11. Percentage of the total cropped area planted with crops for water-budget areas in the Grasslands area of the central part of the western San Joaquin Valley, California, water years 1972-2000. A, Areas that receive water from the Delta Mendota Canal (DMC), the Mendota Pool, and the Fresno Slough. $\boldsymbol{B}$, Areas that receive water from the San Luis Canal (SLC). 
increased significantly throughout the 1970s in those areas that receive water primarily from the SLC (fig. 11B). The lack of significant decreases in crop acreage during drought years in many areas probably is due to reliance on ground water, although the data for some areas may be biased by the use of USBR coming-year crop acreage projections.

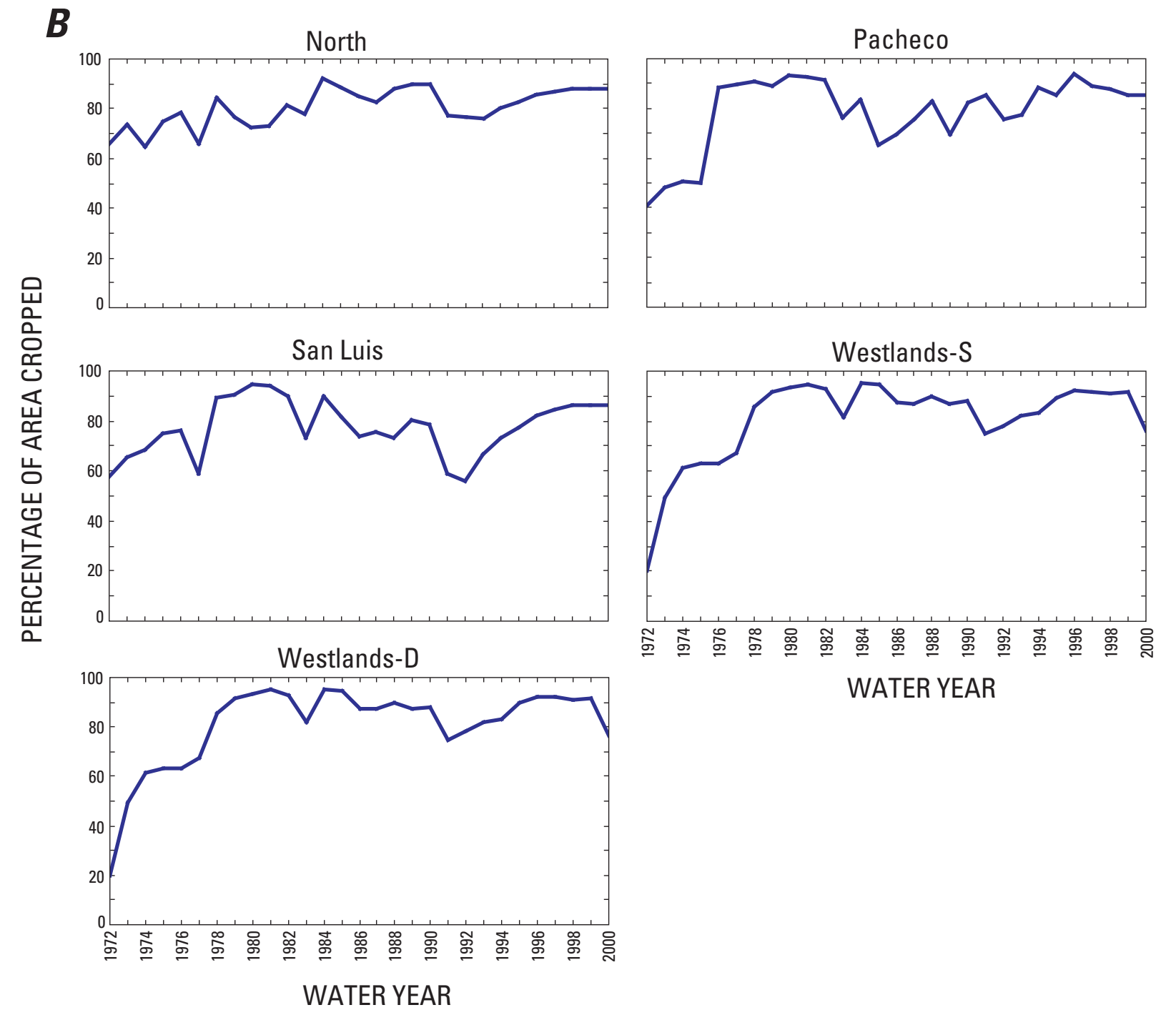

Figure 11. Continued. 
Trends in surface-water deliveries to the water-budget areas during the study period (fig. 12) were similar to trends in cropped acreages. In areas that receive water from the DMC, the maximum surface-water delivery rate did not increase significantly between 1972 and 2000 (fig. 12A). In most of the areas that receive water from the SLC, the surface-water delivery rate increased during the 1970s (fig. 12B). The large fluctuations in surface-water deliveries to CCID-Camp 13 (fig. $12 \mathrm{~A}$ ) probably reflect errors due to the use of area-weighted average of deliveries to the CCID.
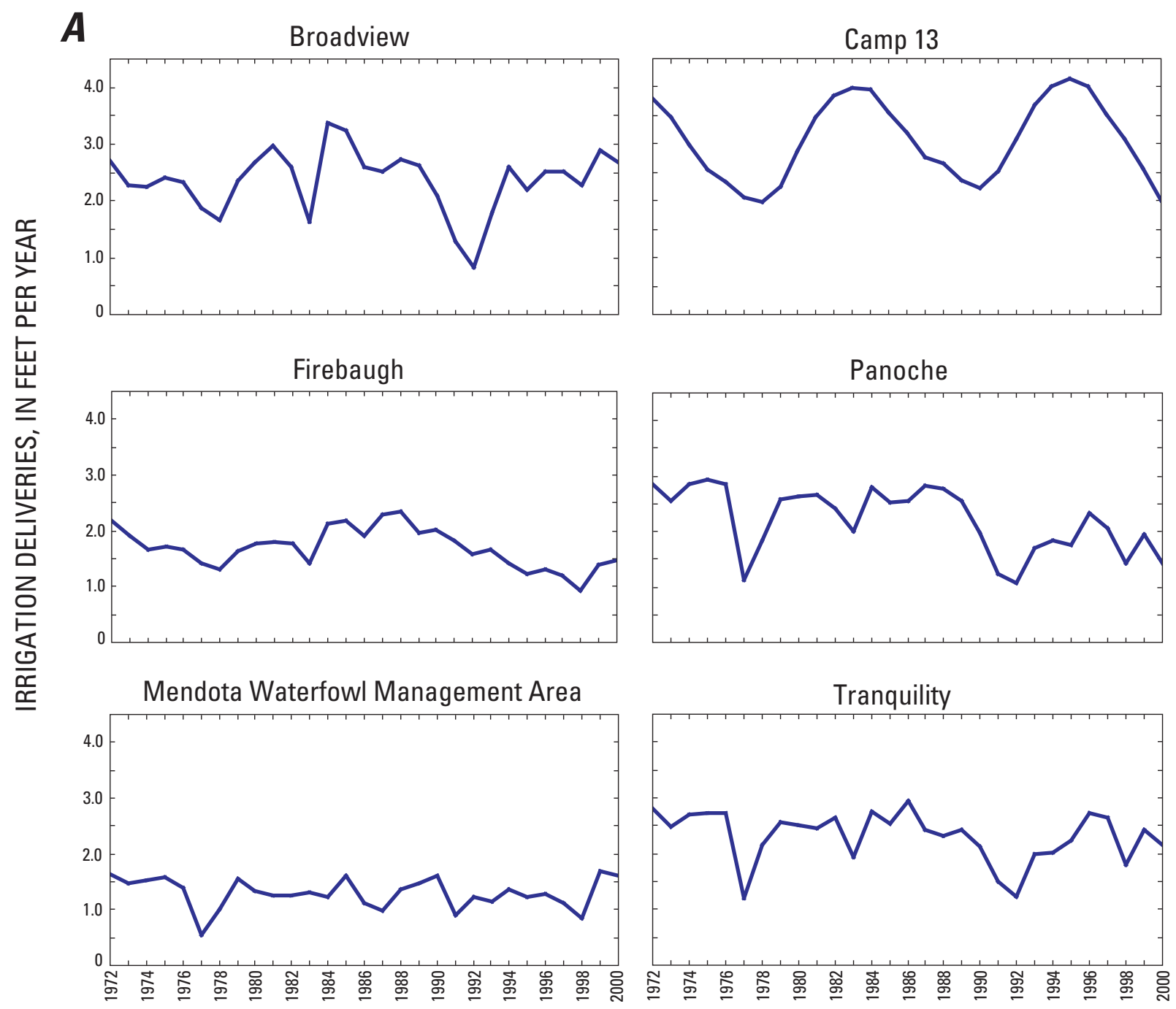

\section{WATER YEAR}

Figure 12. Irrigation water delivery rates for water-budget areas in the Grasslands area of the central part of the western San Joaquin Valley, California, water years 1972-2000. A, Areas that receive water from the Delta Mendota Canal (DMC), the Mendota Pool, and the Fresno Slough. $\boldsymbol{B}$, Areas that receive water from the San Luis Canal (SLC). 


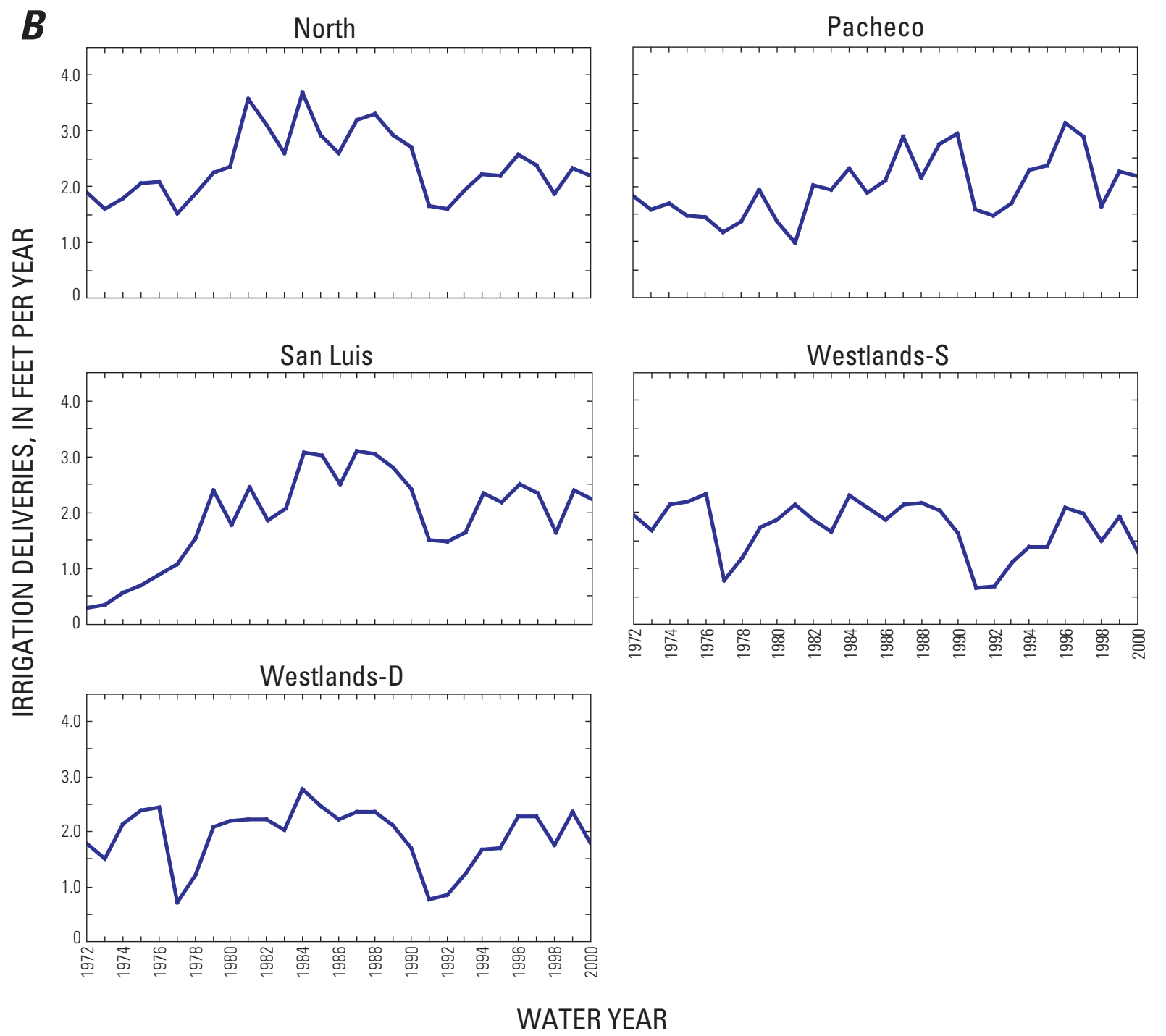

Figure 12. Continued. 


\section{Water-Budget Inputs}

Water-budget inputs for water years 1972 through 2000 are shown in figures $13 \mathrm{~A}$ and $13 \mathrm{~B}$. As figure $13 \mathrm{~A}$ indicates, weekly $E T_{0}$ is fairly consistent from year to year. The maximum fluctuation in annual total $E T_{0}$ for the study period was 15 percent from the mean. Figure $13 B$ shows how the weekly total crop water demand is influenced by both the crop $K_{c}$ and the percentage of the area that is cropped. During the 1970s, the crop water demand in the study area increased as crop acreages increased, with some annual fluctuation owing to varying $E T_{0}$. In drought years, crop acreages were reduced and the total crop water demand declined.

The total crop demand curve for 1989 (fig. 13C) shows the influence of crop $K_{c}$ and planting dates. Agricultural crops generally consume less water than the reference crop used to determine $E T_{0}$. The growing seasons for most agricultural crops are concentrated in the spring, summer, and fall. The difference between the total demand and unmet demand curves represents crop water demands met with effective precipitation. The rightward shift of the curve for unmet demand from the weekly $E T_{c}$ from January through June (fig. 13C) is due to
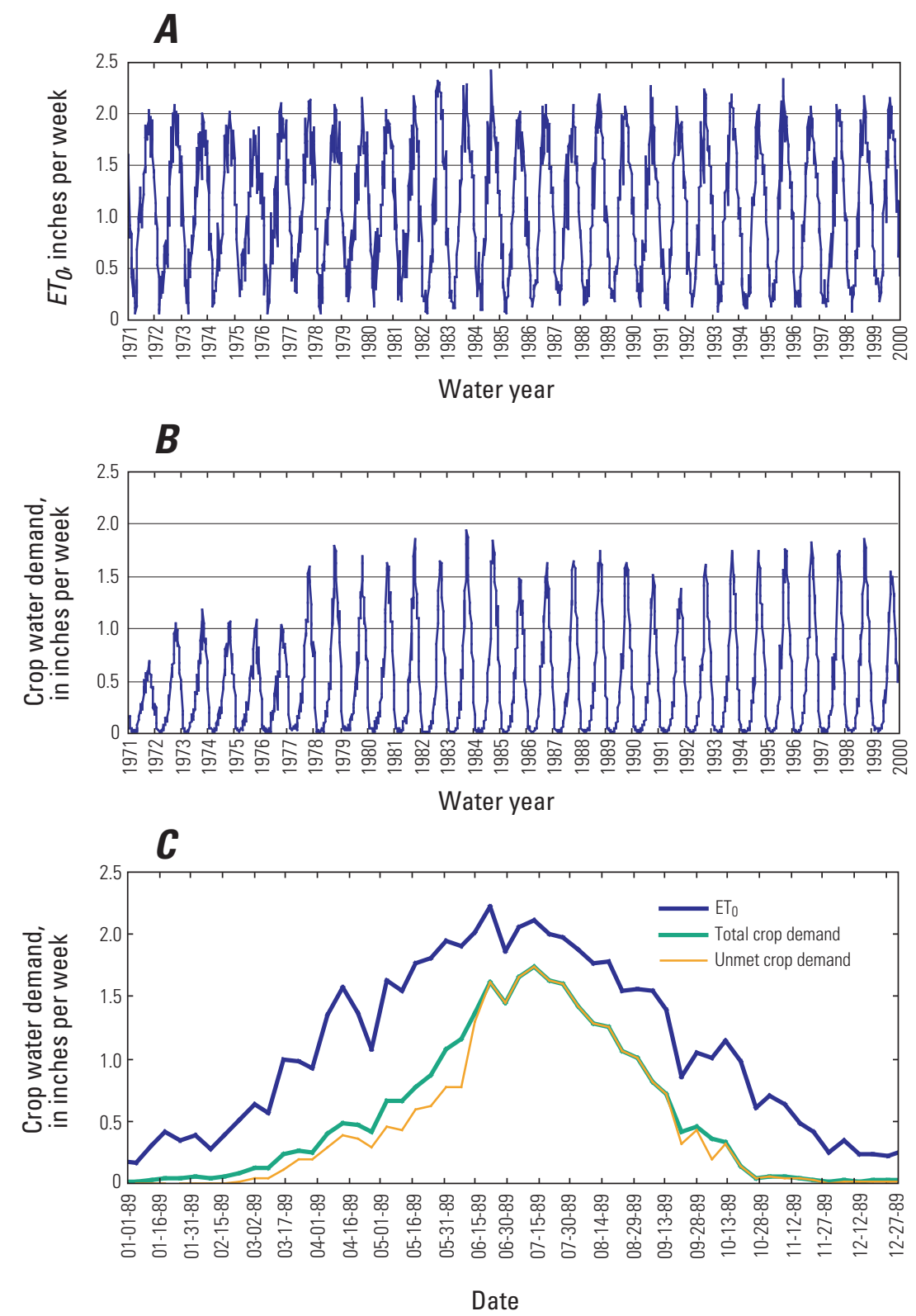

Figure 13. (A) Weekly reference evapotranspiration $\left(E T_{0}\right)$ for the central part of the western San Joaquin Valley, California, water years 1972-2000, and $(\boldsymbol{B})$ weekly total crop water demand for the Grasslands area of the central part of the western San Joaquin Valley, California, water years 1972-2000, and (C) weekly reference evapotranspiration, total crop water demand, and unmet crop water demand for the study area for 1989. 
the staggered planting dates of agricultural crops and indicates that effective precipitation (crop water demand met with precipitation) satisfies approximately the first 2 weeks of crop water demand for each cropped acre. Omitting the contributions of effective precipitation would lead to an overestimate of irrigation demand.

Crop water demand, effective precipitation, and remaining unmet crop water demand for water years 1972 through 2000, averaged for the entire study area, are shown in figure 14. Effective precipitation was greater in the 1990s than in previous decades, perhaps owing to the higher average annual precipitation in the 1990s. Crop water demand increased significantly during the growth period, remained relatively stable during the abundance period, declined during the period of drought, and then increased to previous levels during the period of reduced supplies. The changes in total crop water demand during the last two periods occurred even though cropped acreage remained constant, suggesting that growers responded to drought by growing less water-intensive crops, then resumed growing more water-intensive crops after the drought.

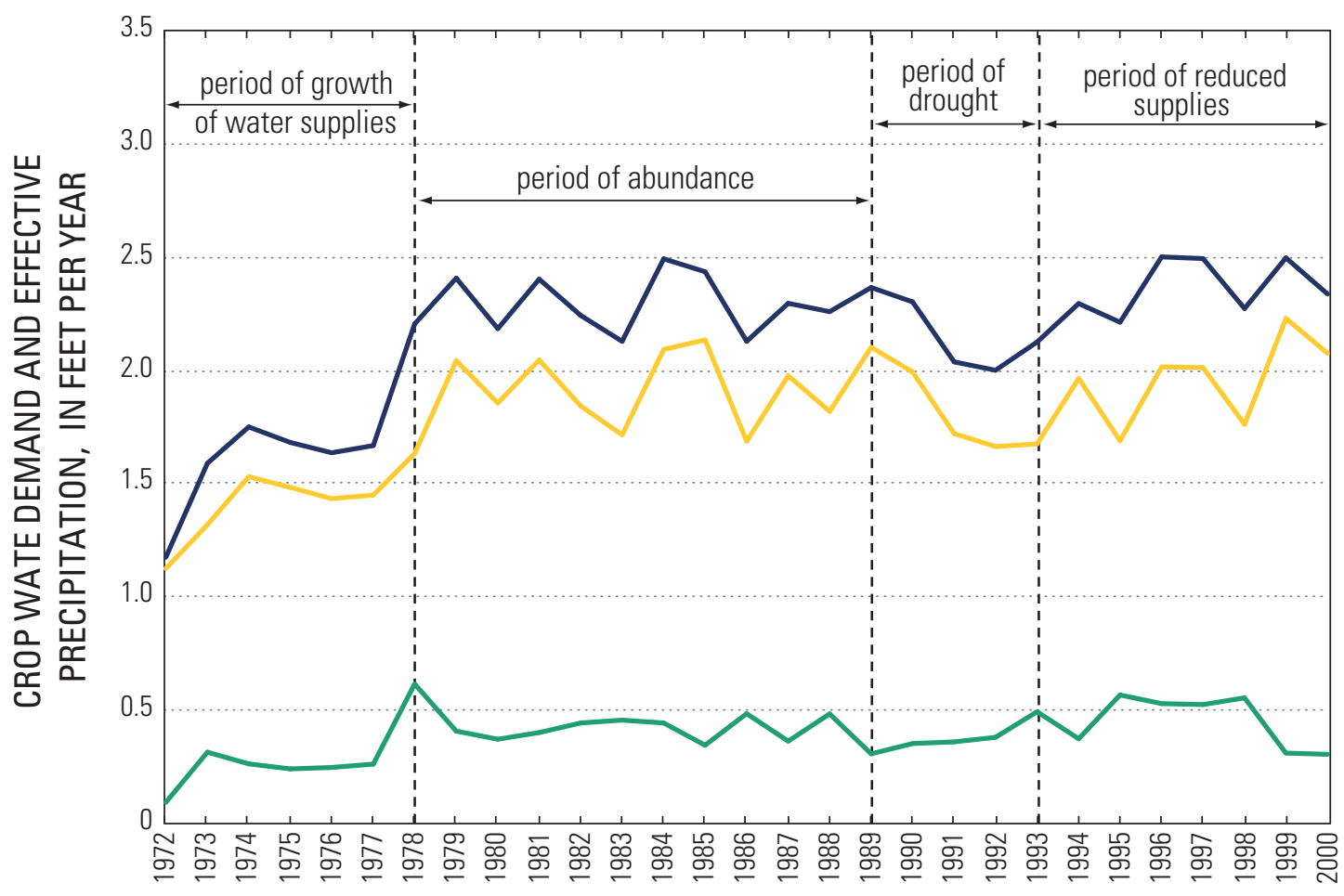

WATER YEAR

\section{EXPLANATION}

Crop water demand _ _ Effective precipitation _ _ Unmet crop water demand

Figure 14. Crop water demand, effective precipitation (crop water demand met with precipitation), and unmet crop water demand for the Grasslands area of the central part of the western San Joaquin Valley, California, water years 1972-2000. 


\section{Climate-Based versus Supply-Based Consumptive Use in Broadview}

To examine the effect of inaccuracies in reported crop acreages on computed ground-water pumpage and recharge rates, the climate-based crop water demand estimate was compared with crop water demand estimated using surface-water delivery data for the Broadview area, where no ground-water pumpage is believed to occur. The supply-based crop water demand estimate divided by the climate-based crop water demand estimate for the Broadview area is presented in figure 15. The ratio is greater than 1.0 from 1980 to 1988 , indicating the supply-based estimate is greater than the climate-based estimate for this period. This agrees with the observation that these were years of abundant surface-water supplies. The ratio is near or below 0.85 for the periods 1977-79 and 1990-92, drought years. Because of limits on available water, it is likely that actual cropped acreage was less than the reported acreage for those years. Thus the climate-based estimate, which relies on reported crop acreages, may overestimate crop water demand for those years. After 1993, the ratio is very close to 1.0 , indicating close agreement between the two estimates.

Growers throughout the study area also are likely to have reduced crop acreages to some extent during drought years. To assess the sensitivity of ground-water pumpage and recharge estimates to the cropped acreages used to formulate the climate-based crop water demand, the annual ratios derived from this analysis of the Broadview water-budget area (fig. 15) were used to adjust crop water demand for the other waterbudget areas for the drought years (1977-79 and 1990-92). In the following sections, ground-water pumpage and recharge estimates adjusted using these ratios are presented along with the climate-based estimates.

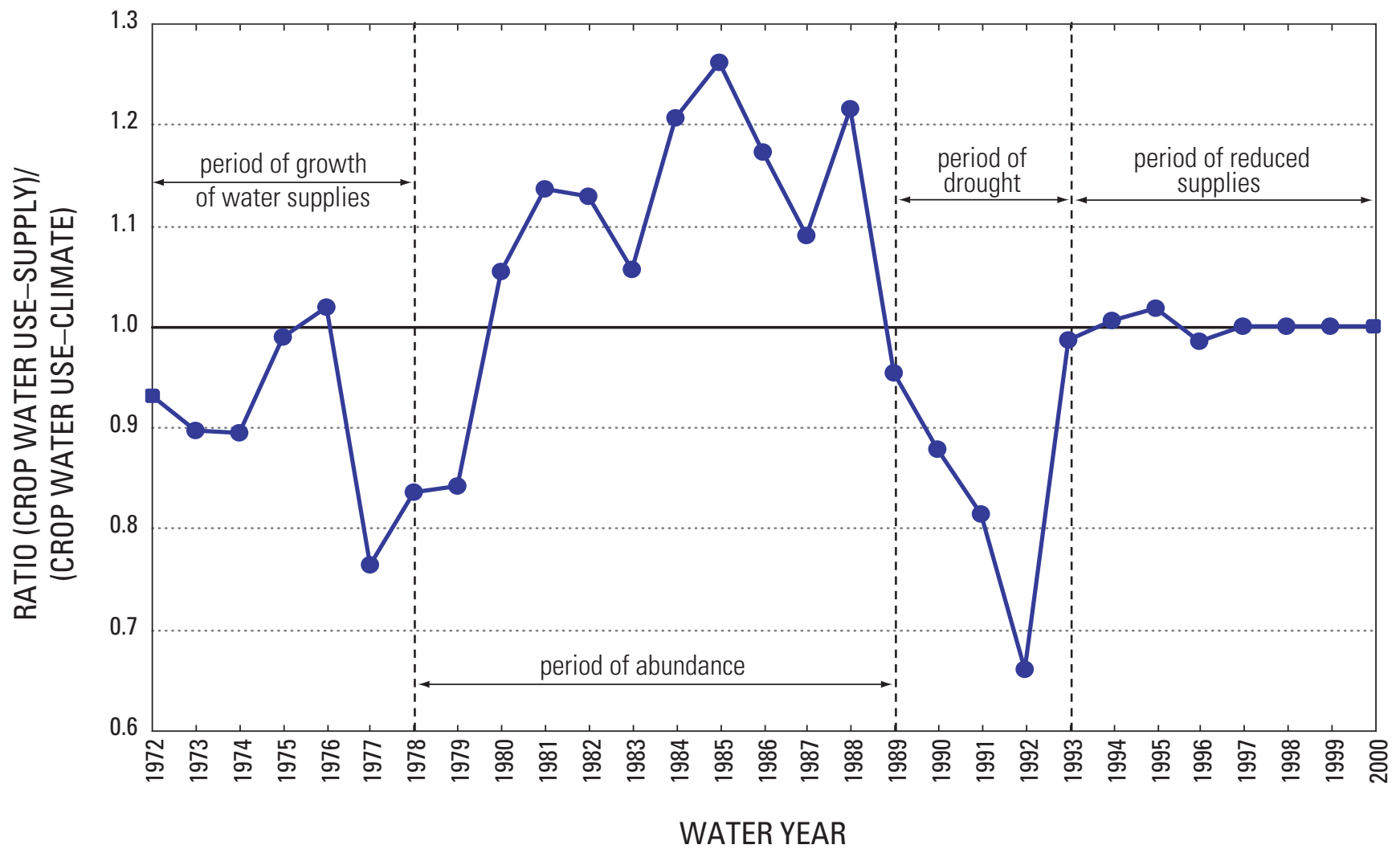

Figure 15. Ratio of the supply-based crop water demand estimate to the climate-based crop water demand estimate for the Broadview water-budget area in the Grasslands area of the central part of the western San Joaquin Valley, California, water years $1972-2000$. Droughts occurred in 1977-1979 and 1990-1992. 


\section{Annual Water-Budget Calculations}

Estimated irrigation demand, total surface-water deliveries, and estimated ground-water pumpage for water years 1972 through 2000 for the entire study area are shown in figure 16 for the four periods of surface-water availability.

Irrigation demand, estimated using the climate-based approach, increased as deliveries from the SLC increased, then remained stable after 1979. Surface-water deliveries were greater than the estimated irrigation demand during the period when the SLC first went into operation, which resulted in little ground-water pumping in the area. The estimated irrigation demand remained greater than the surface-water deliveries after the 1977 drought, remaining relatively steady from 1979 to 2000, declining only during the severest drought years. Estimated ground-water pumpage peaked during the 1977 drought, declined steadily from 1979 to 1988 , and then increased sharply during the extended drought years of 1990-92. Annual water-budget calculations for 1993-2000, suggest that ground water has played a greater role in maintaining a relatively constant irrigation supply (perhaps, in part, because growers continued to use the wells installed during the drought years of the early 1990s).

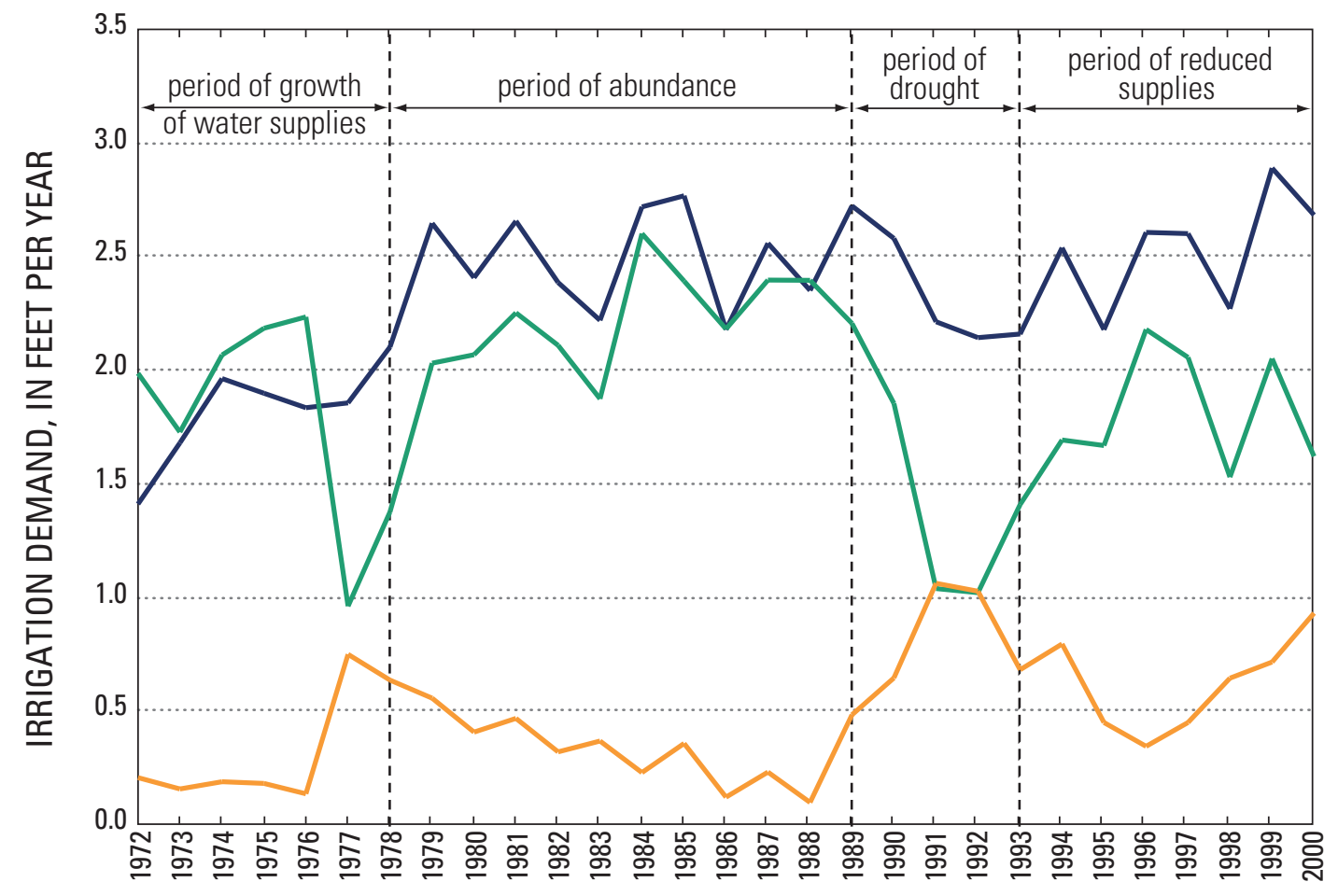

WATER YEAR

\section{EXPLANATION}

Estimated irrigation demand _ $\quad$ Surface-water deliveries _ Ground-water pumpage

Figure 16. Estimated irrigation demand, surface-water deliveries, and estimated ground-water pumpage for the Grasslands area of the central part of the western San Joaquin Valley, California, water years 1972-2000. Irrigation demand equals unmet crop water demand after using effective precipitation divided by the consumption-distribution ratio $R$. 


\section{Estimated Annual Ground-Water Pumpage}

Estimated rates of ground-water pumpage for the 11 water-budget areas are presented in figure 17, table 4 , and Appendix D. The light blue line in each figure is the pumpage estimate calculated after adjusting the crop water demand downward for drought years; the estimate was based on the results of the comparison between climate-based and supplybased estimation methods for the Broadview water-budget area. The adjusted drought-year pumpage rates are lower than unadjusted pumpage rates for all water-budget areas where pumping occurs.
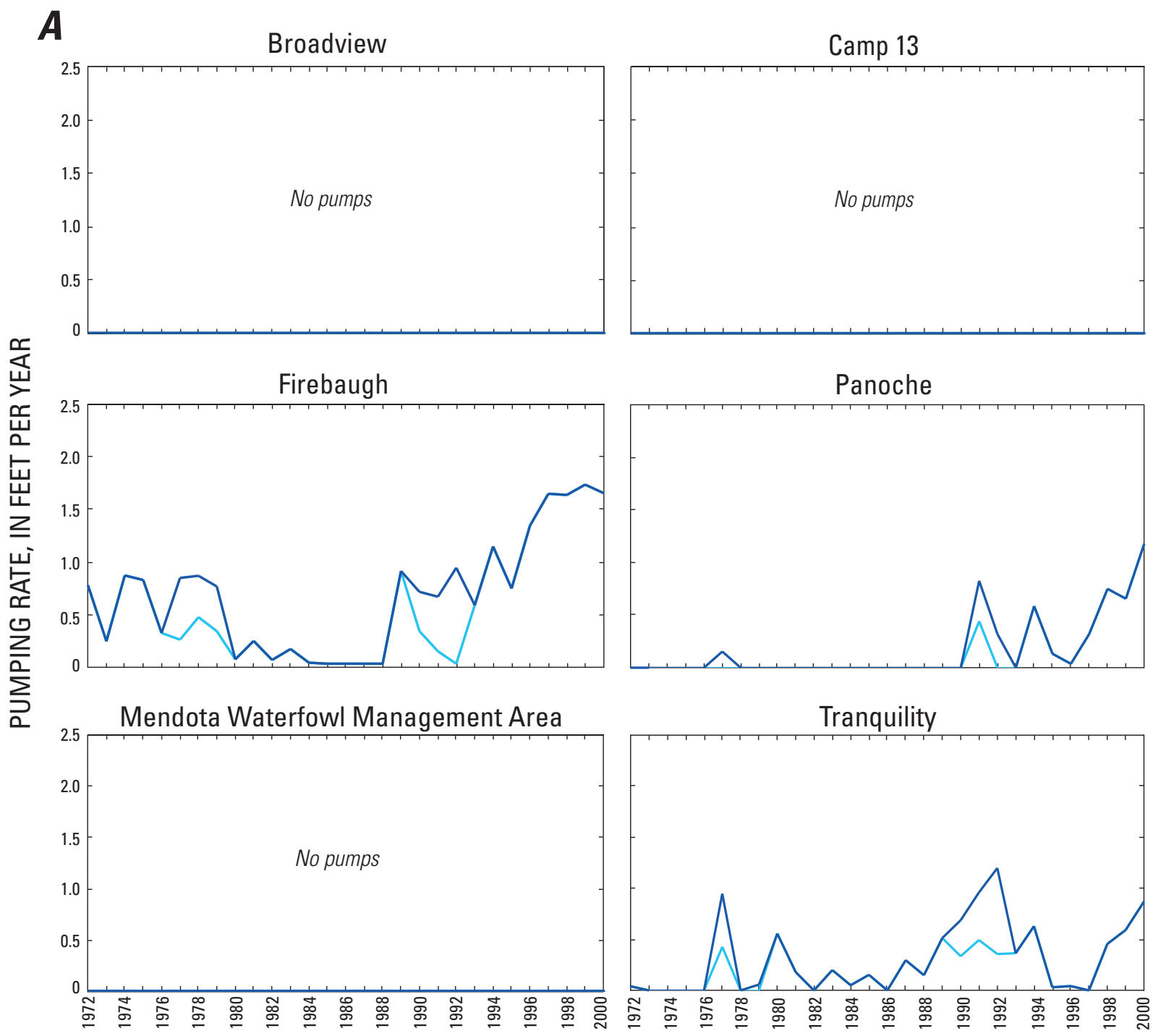

WATER YEAR

Figure 17. Estimated annual ground-water pumpage rates for the water-budget areas in the Grasslands area of the central part of the western San Joaquin Valley, California, water years 1972-2000. A, Areas that receive water from the Delta Mendota Canal (DMC), the Mendota Pool, and the Fresno Slough. $\boldsymbol{B}$, Areas that receive water from the San Luis Canal (SLC). (The light blue line indicates pumpage rates calculated for drought years using an adjusted crop water demand.) 


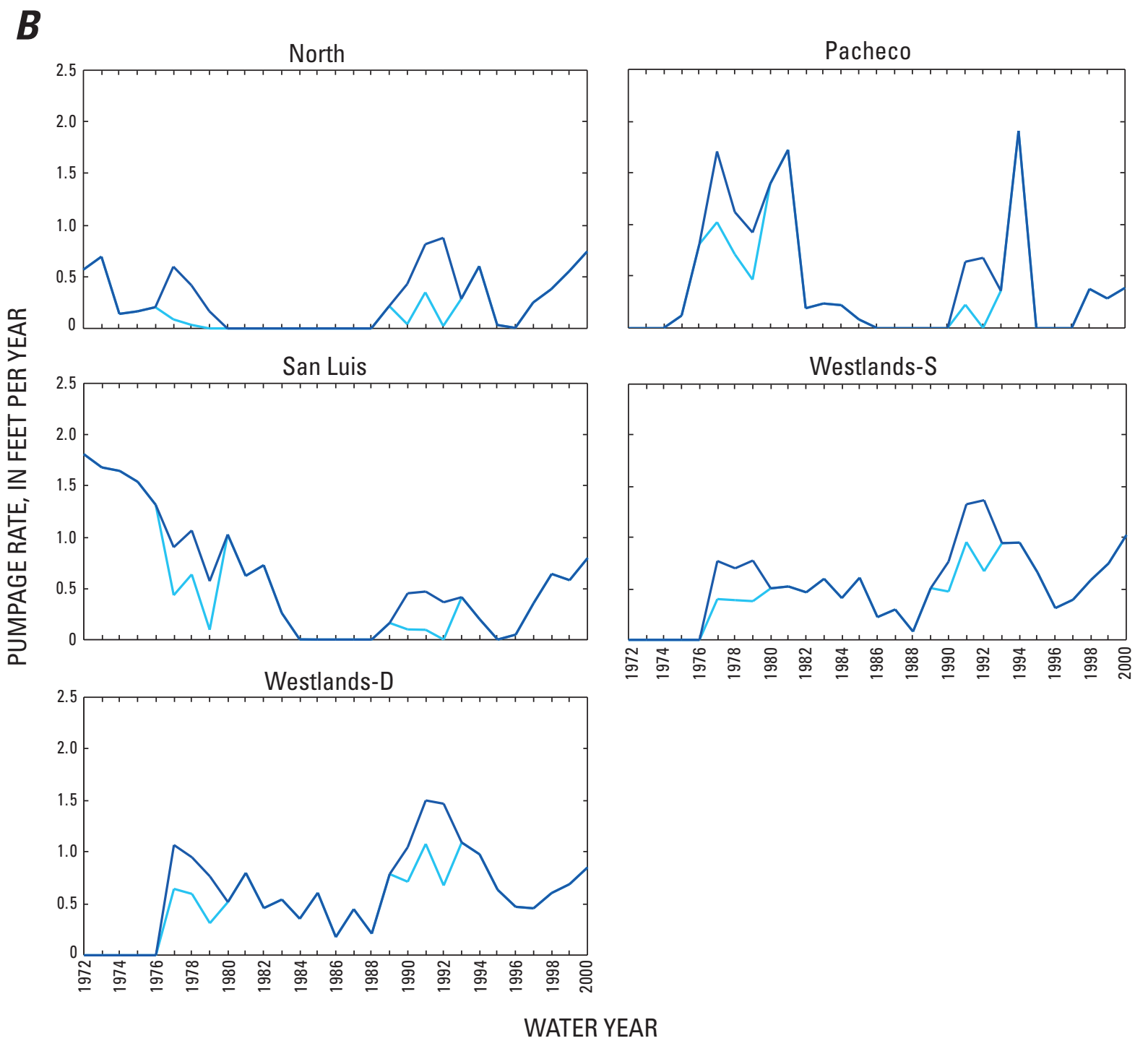

Figure 17. Continued. 
It was assumed that no pumping occurred in three waterbudget areas: Broadview, CCID-Camp 13, and Mendota WMA. Results indicate the Firebaugh area relied somewhat on ground water prior to 1980, used little ground water during the 1980s, and then steadily increased reliance on ground water after 1989. The increase in pumpage in the 1990s may partly be due to an increase in double-cropping in this area, indicated by the cropping data. (Double-cropping is the practice of growing a summer-season crop and a winter-season crop on a single field.) Growers in the Panoche area appear to have increased their reliance on ground water since 1990. The estimates for the Tranquility area suggest that growers in this area have always relied on ground water to supplement surfacewater supplies; prior to 1998, adjusted drought-year pumpage rates for the Tranquility area remained below a maximum pumpage rate of approximately $0.5 \mathrm{ft} / \mathrm{yr}$.

Results for the North and San Luis water-budget areas suggest decreased reliance on ground water as the SLC went into service, but continued reliance on ground water during years of limited surface-water supplies. The estimated

Table 4. Estimated annual ground-water pumpage for the Grasslands area of the central part of the western San Joaquin Valley, California.

[MWMA, Mendota Waterfowl Management Area; DD, drainage district]

\begin{tabular}{|c|c|c|c|c|c|c|c|c|c|c|c|c|}
\hline $\begin{array}{l}\text { Water } \\
\text { Year }\end{array}$ & $\begin{array}{l}\text { Broad- } \\
\text { view }\end{array}$ & $\begin{array}{c}\text { Camp- } \\
13\end{array}$ & $\begin{array}{c}\text { Fire- } \\
\text { baugh }\end{array}$ & MWMA & North & Pacheco & $\begin{array}{c}\text { Panoche } \\
\text { DD }\end{array}$ & $\begin{array}{l}\text { San } \\
\text { Luis }\end{array}$ & Tranquility & $\begin{array}{l}\text { West- } \\
\text { lands-D }\end{array}$ & $\begin{array}{l}\text { West- } \\
\text { lands-S }\end{array}$ & $\begin{array}{l}\text { Study } \\
\text { Area }\end{array}$ \\
\hline 1972 & 0.00 & 0.00 & 0.67 & 0.00 & 0.56 & 0.00 & 0.00 & 1.79 & 0.04 & 0.00 & 0.00 & 0.20 \\
\hline 1973 & .00 & .00 & .21 & .00 & .68 & .00 & .00 & 1.66 & .00 & .00 & .00 & .15 \\
\hline 1974 & .00 & .00 & .75 & .00 & .14 & .00 & .00 & 1.63 & .00 & .00 & .00 & .18 \\
\hline 1975 & .00 & .00 & .71 & .00 & .16 & .12 & .00 & 1.52 & .00 & .00 & .00 & .18 \\
\hline 1976 & .00 & .00 & .28 & .00 & .20 & .81 & .00 & 1.30 & .00 & .00 & .00 & .13 \\
\hline 1977 & .00 & .00 & .73 & .00 & .59 & 1.70 & .15 & .89 & .92 & 1.07 & .77 & .75 \\
\hline 1978 & .00 & .00 & .74 & .00 & .41 & 1.12 & .00 & 1.06 & .00 & .95 & .70 & .63 \\
\hline 1979 & .00 & .00 & .66 & .00 & .16 & .92 & .00 & .57 & .06 & .76 & .77 & .55 \\
\hline 1980 & .00 & .00 & .07 & .00 & .00 & 1.39 & .00 & 1.02 & .54 & .51 & .50 & .40 \\
\hline 1981 & .00 & .00 & .22 & .00 & .00 & 1.72 & .00 & .62 & .17 & .80 & .52 & .46 \\
\hline 1982 & .00 & .00 & .06 & .00 & .00 & .19 & .00 & .72 & .00 & .46 & .46 & .32 \\
\hline 1983 & .00 & .00 & .15 & .00 & .00 & .24 & .00 & .26 & .19 & .54 & .60 & .36 \\
\hline 1984 & .00 & .00 & .04 & .00 & .00 & .22 & .00 & .00 & .05 & .35 & .41 & .22 \\
\hline 1985 & .00 & .00 & .03 & .00 & .00 & .08 & .00 & .00 & .15 & .60 & .61 & .35 \\
\hline 1986 & .00 & .00 & .03 & .00 & .00 & .00 & .00 & .00 & .00 & .18 & .22 & .12 \\
\hline 1987 & .00 & .00 & .03 & .00 & .00 & .00 & .00 & .00 & .29 & .45 & .30 & .23 \\
\hline 1988 & .00 & .00 & .03 & .00 & .00 & .00 & .00 & .00 & .14 & .21 & .08 & .09 \\
\hline 1989 & .00 & .00 & .78 & .00 & .21 & .00 & .00 & .16 & .050 & .78 & .50 & .48 \\
\hline 1990 & .00 & .00 & .61 & .00 & .42 & .00 & .00 & .45 & .66 & 1.05 & .76 & .64 \\
\hline 1991 & .00 & .00 & .57 & .00 & .80 & .64 & .82 & .46 & .93 & 1.50 & 1.32 & 1.06 \\
\hline 1992 & .00 & .00 & .81 & .00 & .86 & .68 & .32 & .36 & 1.16 & 1.47 & 1.36 & 1.02 \\
\hline 1993 & .00 & .00 & .51 & .00 & .28 & .36 & .00 & .41 & .35 & 1.09 & .94 & .68 \\
\hline 1994 & .00 & .00 & .98 & .00 & .59 & 1.90 & .58 & .20 & .61 & .98 & .95 & .79 \\
\hline 1995 & .00 & .00 & .64 & .00 & .03 & .00 & .13 & .00 & .03 & .63 & .66 & .44 \\
\hline 1996 & .00 & .00 & 1.15 & .00 & .01 & .00 & .04 & .05 & .04 & .47 & .31 & .34 \\
\hline 1997 & .00 & .00 & 1.40 & .00 & .25 & .00 & .32 & .35 & .00 & .45 & .39 & .44 \\
\hline 1998 & .00 & .00 & 1.39 & .00 & .37 & .38 & .75 & .64 & .44 & .60 & .58 & .64 \\
\hline 1999 & .00 & .00 & 1.48 & .00 & .54 & .28 & .65 & .57 & .57 & .69 & .75 & .71 \\
\hline 2000 & .00 & .00 & 1.41 & .00 & .73 & .39 & 1.17 & .79 & .84 & .85 & 1.02 & .93 \\
\hline Average & .00 & .00 & .59 & .00 & .28 & .45 & .17 & .60 & .30 & .60 & .53 & .46 \\
\hline $\begin{array}{l}\text { Average } \\
1972-88\end{array}$ & .00 & .00 & .32 & .00 & .17 & .50 & .01 & .77 & .15 & .40 & .35 & .31 \\
\hline
\end{tabular}


pumpage rates for the Pacheco area indicate a heavy reliance on ground water; growers in this area also pump ground water for export to other areas (San Luis and Delta-Mendota Water Authority, 1995). Ground-water pumpage estimates for the Westlands-S and the Westlands-D areas indicate a reliance on ground water to supplement decreased surface-water supplies during the 1977 and the 1990-93 droughts, followed by supplemental ground-water usage in all years except those with significant surface-water supplies. For all areas, the droughtadjusted peak pumpage rates are lower than the unadjusted pumpage rates.

\section{Estimated Annual Ground-Water Recharge}

Ground-water recharge rates for the 11 water-budget areas are presented in figure 18, table 5, and Appendix D. The light blue line in figure 18, representing the recharge calculated after adjusting the crop water demand estimate downward in drought years, reflects the sensitivity of the recharge estimate to crop acreage.

The Broadview, CCID-Camp 13, Firebaugh, Panoche, and Tranquility water-budget areas do not receive water from the SLC. Recharge rates for the Broadview and CCID-Camp

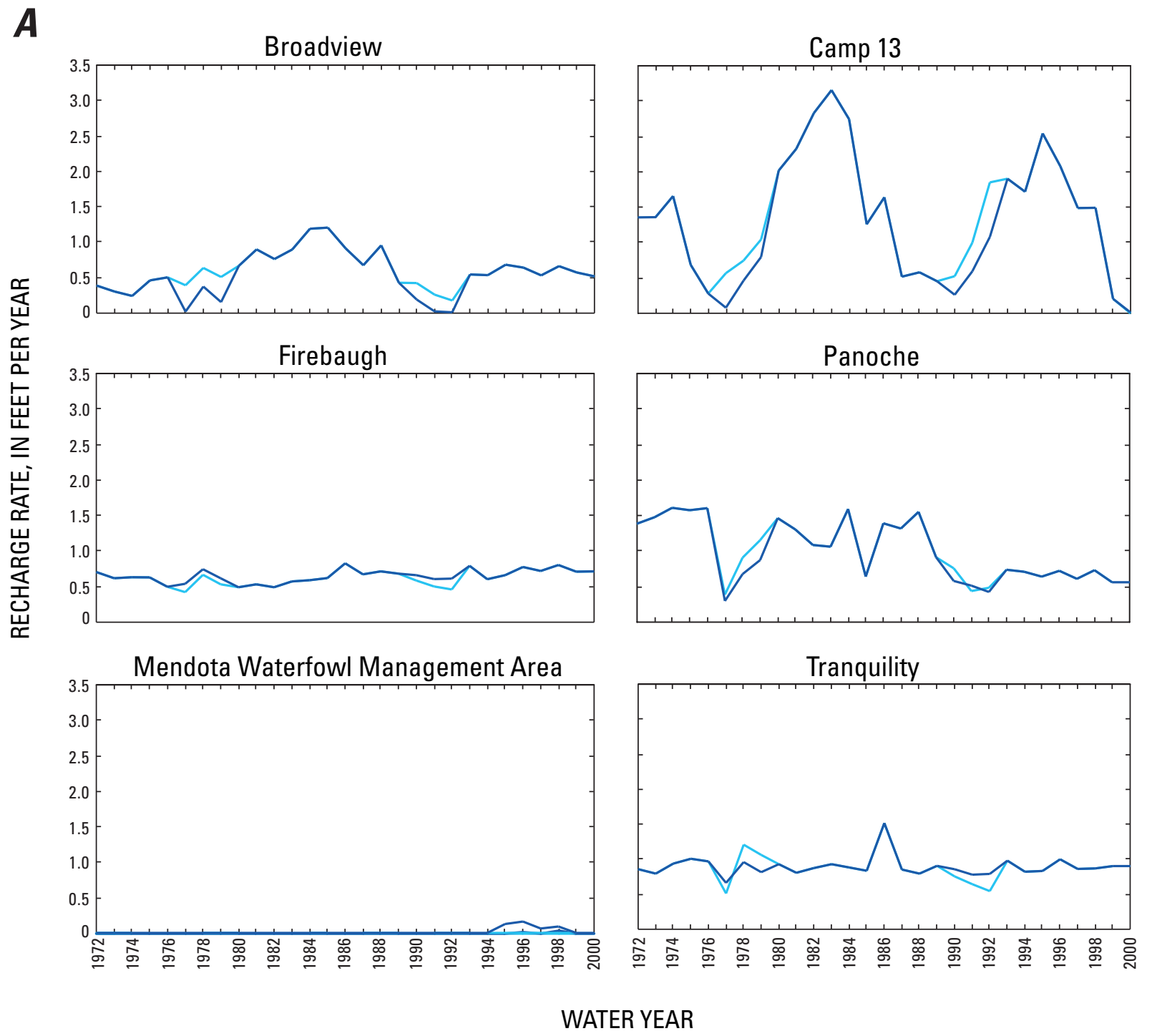

Figure 18. Estimated annual ground-water recharge rates for the water-budget areas in the Grasslands area of the central part of the western San Joaquin Valley, California, water years 1972-2000. A, Areas that receive water from the Delta Mendota Canal (DMC), the Mendota Pool, and the Fresno Slough. B, Areas that receive water from the San Luis Canal (SLC). (The light blue line indicates recharge rates calculated for drought years using an adjusted crop water demand.) 
13 areas fluctuate, apparently in response to surface-water availability. The recharge rate for the CCID-Camp 13 area appears to be very high, perhaps owing to inaccuracies in the reported surface-water deliveries to this area. Recharge rates for the Firebaugh and Tranquility water-budget areas have remained relatively constant with some fluctuations owing to drought. The recharge rate for the Panoche area shows a sharp decline after 1990, perhaps because of reduced surfacewater imports and increased drain water recycling. Calculated recharge rates determined using the adjusted crop acreages were higher than the unadjusted recharge rates for the Broadview, CCID-Camp-13, and Panoche areas for both drought periods, and for Tranquility for the 1977-79 drought period.

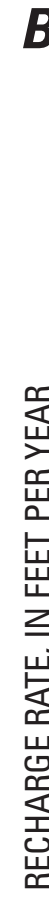
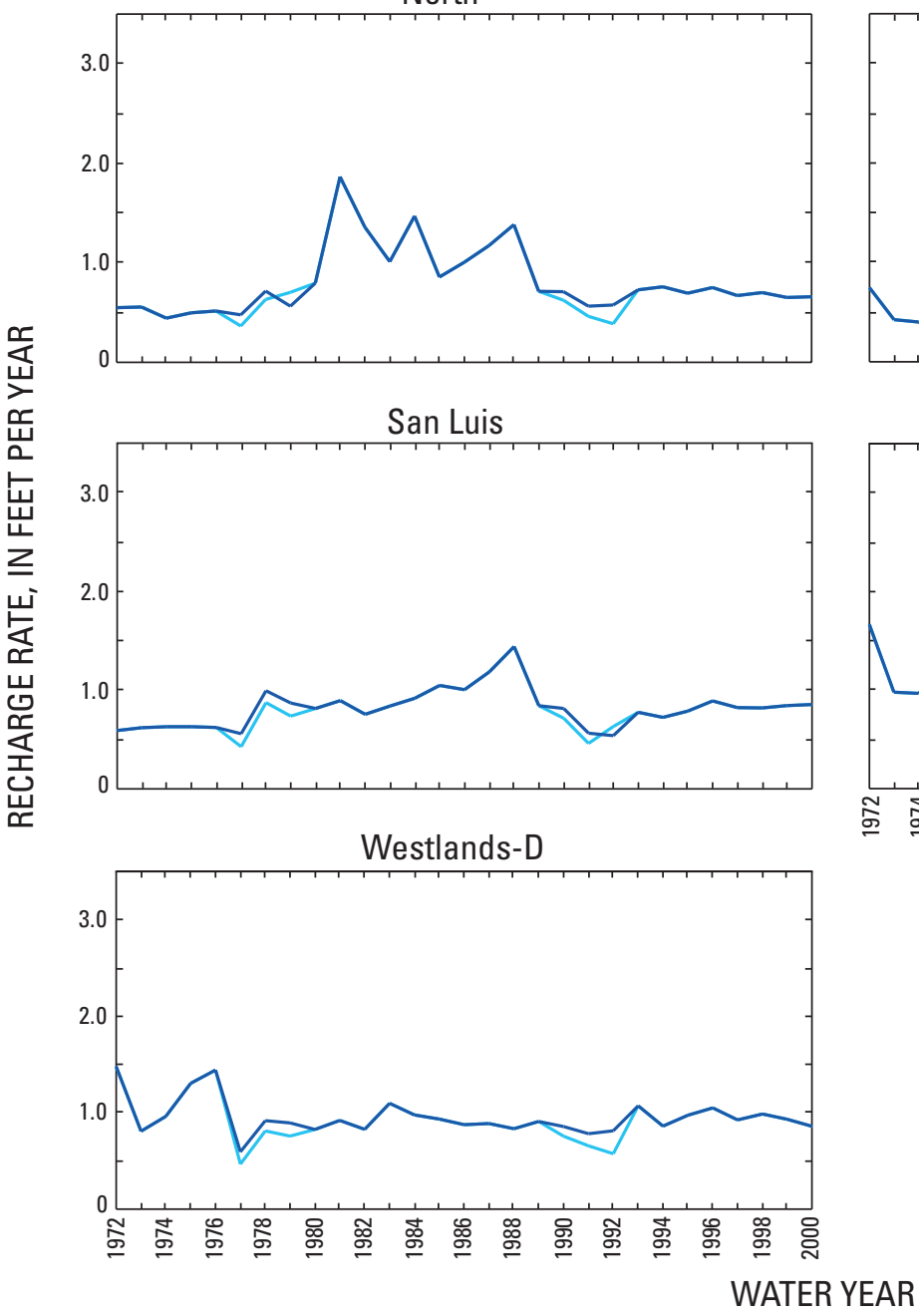

Pacheco

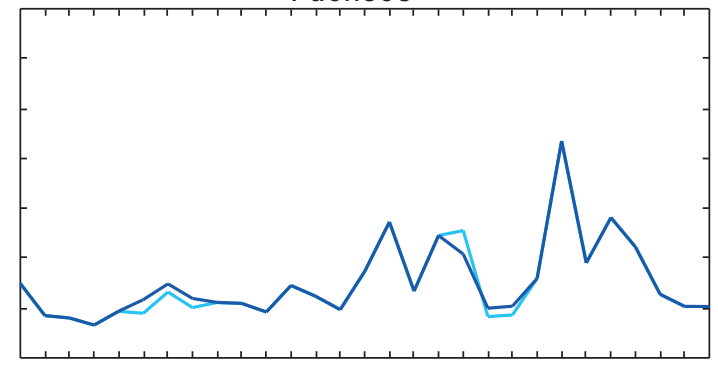

Westlands-S

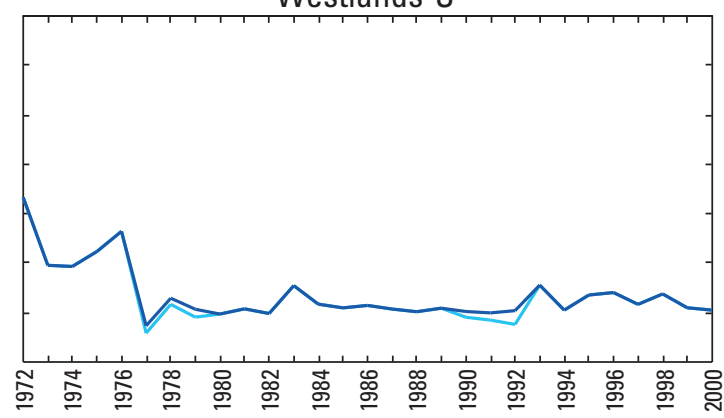

Figure 18. Continued. 
Estimated recharge rates for the North water-budget area indicate that recharge was stable from 1972 to 1979, elevated during the years with abundant supplies (1980s), and stable during the 1990s, years of drought and constrained supplies (fig. 18). Estimated recharge rates for the San Luis waterbudget area indicate that recharge also was stable from 1972 to 1977 and again from 1979 to 1980 , rose from 1980 through 1989 , fell during the drought years of the early 1990s, and then rose to a stable level in the late 1990s. Recharge rates in the Pacheco area closely follow the surface-water supply (fig. $12 B$ ) which, with the exception of drought years, increased steadily from 1972 to 1996, then fell between 1998 and 2000. Recharge rates in the Westlands-S and Westlands-D waterbudget areas declined from 1972 to 1977, and then remained relatively constant. Recharge rates calculated using adjusted crop water demand for the drought years are slightly lower for most areas; where they are higher, it is likely that crop acreages were not significantly adjusted.

Table 5. Estimated annual ground-water recharge rates for the water-budget areas of the Grasslands area of the central part of the western San Joaquin Valley, California.

[MWMA, Mendota Waterfowl Management Area; DD, drainage district]

\begin{tabular}{|c|c|c|c|c|c|c|c|c|c|c|c|c|}
\hline $\begin{array}{l}\text { Water } \\
\text { Year }\end{array}$ & $\begin{array}{l}\text { Broad- } \\
\text { view }\end{array}$ & Camp-13 & $\begin{array}{c}\text { Fire- } \\
\text { baugh }\end{array}$ & MWMA & North & Pacheco & $\begin{array}{l}\text { Panoche } \\
\text { DD }\end{array}$ & $\begin{array}{l}\text { San } \\
\text { Luis }\end{array}$ & $\begin{array}{l}\text { Tranquil- } \\
\text { ity }\end{array}$ & $\begin{array}{l}\text { Westlands- } \\
\text { D }\end{array}$ & $\begin{array}{l}\text { Westlands- } \\
\text { S }\end{array}$ & $\begin{array}{l}\text { Study } \\
\text { Area }\end{array}$ \\
\hline 1972 & 0.39 & 1.30 & 0.60 & 0.00 & 0.54 & 0.74 & 1.37 & 0.58 & 0.83 & 1.48 & 1.66 & 1.25 \\
\hline 1973 & .30 & 1.30 & .52 & .00 & .55 & .42 & 1.47 & .61 & .77 & .81 & .98 & .86 \\
\hline 1974 & .24 & 1.59 & .54 & .00 & .44 & .40 & 1.60 & .62 & .91 & .96 & .97 & .93 \\
\hline 1975 & .46 & .66 & .53 & .00 & .49 & .33 & 1.56 & .62 & .97 & 1.30 & 1.12 & 1.06 \\
\hline 1976 & .50 & .27 & .42 & .00 & .51 & .46 & 1.59 & .62 & .94 & 1.44 & 1.32 & 1.14 \\
\hline 1977 & .02 & .08 & .46 & .00 & .47 & .58 & .29 & .55 & .64 & .59 & .37 & .44 \\
\hline 1978 & .37 & .44 & .63 & .00 & .70 & .74 & .67 & .98 & .93 & .91 & .65 & .74 \\
\hline 1979 & .15 & .76 & .52 & .00 & .55 & .59 & .87 & .86 & .79 & .89 & .53 & .69 \\
\hline 1980 & .67 & 1.93 & .42 & .00 & .78 & .55 & 1.45 & .81 & .90 & .82 & .49 & .77 \\
\hline 1981 & .90 & 2.22 & .45 & .00 & 1.83 & .54 & 1.29 & .88 & .78 & .92 & .54 & .83 \\
\hline 1982 & .76 & 2.71 & .42 & .00 & 1.33 & .46 & 1.08 & .75 & .85 & .83 & .49 & .74 \\
\hline 1983 & .90 & 3.02 & .49 & .00 & .99 & .72 & 1.05 & .83 & .90 & 1.09 & .77 & .91 \\
\hline 1984 & 1.19 & 2.63 & .50 & .00 & 1.44 & .61 & 1.58 & .91 & .85 & .97 & .59 & .91 \\
\hline 1985 & 1.20 & 1.21 & .53 & .00 & .84 & .48 & .63 & 1.04 & .81 & .93 & .55 & .73 \\
\hline 1986 & .91 & 1.57 & .70 & .00 & .99 & .87 & 1.38 & 1.00 & 1.46 & .87 & .57 & .87 \\
\hline 1987 & .67 & .50 & .57 & .00 & 1.15 & 1.36 & 1.31 & 1.17 & .82 & .88 & .54 & .81 \\
\hline 1988 & .95 & .56 & .61 & .00 & 1.36 & .67 & 1.54 & 1.43 & .77 & .83 & .51 & .84 \\
\hline 1989 & .43 & .44 & .58 & .00 & .70 & 1.22 & .91 & .83 & .88 & .91 & .54 & .73 \\
\hline 1990 & .19 & .25 & .56 & .00 & .70 & 1.04 & .57 & .81 & .83 & .85 & .51 & .65 \\
\hline 1991 & .02 & .57 & .51 & .00 & .56 & .49 & .51 & .56 & .75 & .78 & .50 & .58 \\
\hline 1992 & .01 & 1.03 & .52 & .00 & .57 & .52 & .42 & .53 & .76 & .81 & .52 & .59 \\
\hline 1993 & .54 & 1.82 & .67 & .00 & .72 & .79 & .73 & .77 & .95 & 1.07 & .78 & .84 \\
\hline 1994 & .53 & 1.64 & .51 & .00 & .75 & 2.17 & .70 & .72 & .79 & .86 & .53 & .70 \\
\hline 1995 & .68 & 2.43 & .56 & .13 & .68 & .95 & .63 & .78 & .81 & .97 & .68 & .78 \\
\hline 1996 & .64 & 1.99 & .66 & .16 & .74 & 1.40 & .71 & .88 & .97 & 1.05 & .70 & .84 \\
\hline 1997 & .53 & 1.42 & .61 & .06 & .66 & 1.11 & .60 & .82 & .83 & .92 & .58 & .72 \\
\hline 1998 & .66 & 1.43 & .68 & .09 & .69 & .63 & .72 & .81 & .84 & .98 & .69 & .79 \\
\hline 1999 & .57 & .20 & .60 & .00 & .64 & .51 & .56 & .84 & .87 & .93 & .55 & .68 \\
\hline 2000 & .52 & .01 & .61 & .00 & .65 & .51 & .56 & .85 & .87 & .86 & .53 & .65 \\
\hline Average & .55 & 1.24 & .55 & .02 & .79 & .75 & .98 & .81 & .86 & .95 & .68 & .80 \\
\hline $\begin{array}{l}\text { Average } \\
\text { 1972-88 }\end{array}$ & .62 & 1.34 & .52 & .00 & .88 & .62 & 1.22 & .84 & .88 & .97 & .74 & .85 \\
\hline
\end{tabular}


Sources of recharge (fig. 19; table 6) include irrigation with surface water and ground water, and precipitation. Contributions of recharge from surface-water irrigation declined during the mid-1970s as growers in the western part of the study area began receiving irrigation water from the SLC, then declined sharply during the 1977 drought. Estimated recharge from irrigation water rebounded slightly during the 1980s, declined during the drought of the early 1990s, and then experienced a less pronounced rebound in the mid- to late 1990s (fig. 19). The overall trend for recharge suggests a continuous reduction in recharge from irrigation that most likely is due to gradual fine-tuning of on-farm irrigation management practices. This fine-tuning may include improvements in irrigation efficiency, such as investments in pressurized irrigation systems and tail-water return systems; adjustments of crop mixes and planting dates to better match periods of peak crop water demand with surface-water delivery schedules; and increased recycling and re-use of agricultural drainage water.

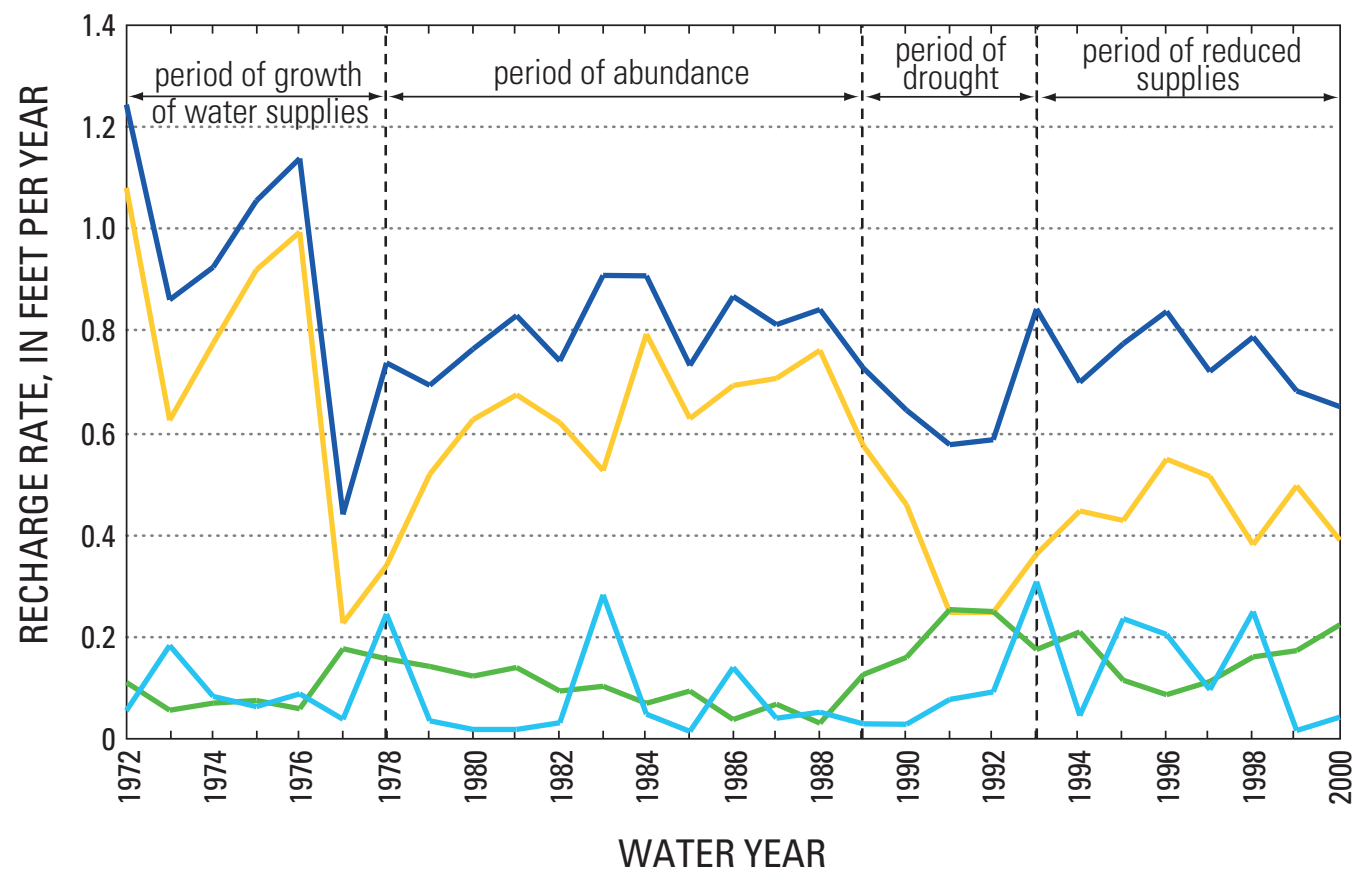

\section{EXPLANATION}

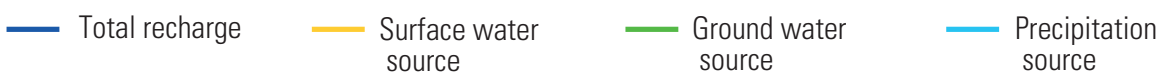

Figure 19. Total annual recharge and recharge from surface water, ground water, and precipitation in the Grasslands area of the central part of the western San Joaquin Valley, California, water years 1972-2000.

Table 6. Estimated average recharge rates from irrigation and precipitation for the Grasslands area of the central part of the western San Joaquin Valley, California, for each of the four delivery periods.

[All values are in feet per year]

\begin{tabular}{lccccc}
\hline \multirow{2}{*}{ Source of recharge } & \multicolumn{5}{c}{ Recharge rates (water years) } \\
\cline { 2 - 6 } & $\mathbf{1 9 7 2 - 7 8}$ & $\mathbf{1 9 7 9 - 8 9}$ & $\mathbf{1 9 9 0 - 9 3}$ & $\mathbf{1 9 9 4 - 2 0 0 0}$ & $\mathbf{1 9 7 2 - 2 0 0 0}$ \\
\hline Irrigation water & 0.81 & 0.74 & 0.54 & 0.61 & 0.70 \\
Precipitation & .11 & .06 & .13 & .13 & .10 \\
Total recharge & .92 & .80 & .66 & .74 & .80 \\
\hline
\end{tabular}


Average annual recharge from precipitation was much greater in the 1990s than in the previous decades (fig. 19). Contributions from precipitation were greater than $0.2 \mathrm{ft}$ in 1978, 1983, 1993, 1995, 1996, and 1998 and were between 0.1 and $0.2 \mathrm{ft}$ in 1973 and 1986. Rates of recharge from precipitation may be important for determining the discharge rates from agricultural drains. It is possible that the higher average rates of recharge from precipitation that occurred in the 1990s, and especially the occurrence of 4 years of above-average recharge from precipitation during a 6-year period (1993-98) are partly responsible for the increased winter discharges from agricultural drains in the late 1990s. These high discharges from the agricultural drains occurred during a period with historically low rates of recharge from irrigation.

\section{Comparison with Other Studies}

Gronberg and Belitz (1992), the Irrigation Training and Research Center (1994), the Westlands Water District $(1996,2004)$ and Summers Engineering (2002) have estimated ground-water pumpage or recharge rates for 1 or more years for portions of the study area. Comparisons of results between these studies are complicated by differences in the data and methodologies used, subarea boundaries, and the years of investigation. The use of a single methodology for the entire study area of this current study facilitated comparisons between time periods and water-budget areas. The current study also benefited from the long timeframe (29 years), the use of a daily soil-surface process model and daily crop water budgets for 66 crops, the increased spatial discretization of 29 data-collection areas, and the availability of more recent data.

The ground-water pumpage and recharge calculated for this study for 1980 and 1984 are significantly different than those calculated by Gronberg and Belitz (1992) for the same years for the six water-budget areas that coincide between the two studies (table 7). The average annual ground-water pumpage and recharge rates from 1972 to 1988 calculated for this study are also significantly different than the 1980 and 1984 values of Gronberg and Belitz (1992). These differences are most likely because they focused on only 2 years and used more detailed surface-water delivery and crop acreage data.

Table 7. Water budgets for 1980 and 1984 for several water-budget areas in the Grasslands area of the central part of the western San Joaquin Valley, California.

[All values are in acre feet per year. Values in italics are area-weighted]

\begin{tabular}{|c|c|c|c|c|c|}
\hline \multirow[b]{2}{*}{$\begin{array}{l}\text { Water-budget } \\
\text { areas }\end{array}$} & \multicolumn{5}{|c|}{ Ground-water pumpage rates } \\
\hline & $\begin{array}{c}1980 \\
\text { (Gronberg } \\
\text { and } \\
\text { Belitz, 1992) }\end{array}$ & $\begin{array}{c}1980 \\
\text { (this study) }\end{array}$ & $\begin{array}{c}1984 \\
\text { (Gronberg and } \\
\text { Belitz, 1992) }\end{array}$ & $\begin{array}{c}1984 \\
\text { (this study) }\end{array}$ & $\begin{array}{c}\text { 1972-88 aver- } \\
\text { age } \\
\text { (this study) }\end{array}$ \\
\hline Broadview & 0.00 & 0.00 & 0.28 & 0.00 & 0.00 \\
\hline Firebaugh & .00 & .07 & .00 & .04 & .32 \\
\hline Panoche DD & .00 & .00 & .00 & .00 & .01 \\
\hline San Luis & .40 & 1.02 & .48 & .00 & .77 \\
\hline Tranquility & .30 & .54 & .00 & .05 & .15 \\
\hline \multirow[t]{3}{*}{ Westlands-S } & .43 & .50 & .12 & .41 & .35 \\
\hline & \multicolumn{5}{|c|}{ Ground-water recharge rates } \\
\hline & $\begin{array}{c}1980 \\
\text { (Gronberg } \\
\text { and } \\
\text { Belitz, 1992) }\end{array}$ & $\begin{array}{c}1980 \\
\text { (this study) }\end{array}$ & $\begin{array}{c}1984 \\
\text { (Gronberg and } \\
\text { Belitz, 1992) }\end{array}$ & $\begin{array}{c}1984 \\
\text { (this study) }\end{array}$ & $\begin{array}{c}1972-88 \\
\text { average } \\
\text { (this study) }\end{array}$ \\
\hline Broadview & 0.78 & 0.67 & 0.59 & 1.19 & 0.62 \\
\hline Firebaugh & .75 & .42 & .74 & .50 & .52 \\
\hline Panoche DD & .96 & 1.45 & .90 & 1.58 & 1.22 \\
\hline San Luis & .79 & .81 & .88 & .91 & .84 \\
\hline Tranquility & .84 & .90 & .88 & .85 & .88 \\
\hline Westlands-S & .60 & .49 & .61 & .59 & .74 \\
\hline
\end{tabular}


The 1989 water budget for Panoche DD for this current study and the one developed by Fio (1994) are presented in table 8 . The surface-water delivery estimate of this study is slightly lower than that of Fio (1994). The values for groundwater pumpage and unmet crop demand, after accounting for effective precipitation, are the same. The 20-percent difference in the ground-water recharge estimates for the two studies reflects the difference in the surface-water delivery estimates.

Table 8. Water budgets for 1989 for the Panoche Drainage District in the Grasslands area of the central part of the western San Joaquin Valley, California.

[All values are in feet per year]

\begin{tabular}{lcc}
\hline & \multicolumn{2}{c}{1989} \\
\cline { 2 - 3 } & Fio, 1994 & This study \\
\hline Surface-water deliveries & 2.8 & 2.6 \\
Ground-water pumpage & .0 & .0 \\
Unmet demand after precipitation & 1.7 & 1.7 \\
Recharge & 1.1 & .9 \\
\hline
\end{tabular}

The Irrigation Training and Research Center (1994) estimated crop water demand and effective precipitation for 1981-92 for six water-budget areas representing approximately 80,000 acres. The daily soil surface process model used in this current study, which incorporates the U.S. Department of Agriculture Soil Conservation Service (SCS) method to estimate runoff for each precipitation event, yielded effective precipitation values 45 percent higher on average than that estimated by the Irrigation Training and Research Center (1994). The daily soil-moisture balance model used in this current study produced annual total crop water demand estimates that are on the average 13 percent higher than those estimated by the Irrigation Training and Research Center (1994).

Ground-water pumpage rates for water years 1976 through 2000 obtained from the Westlands Water District $(1996,1999,2004)$ and estimates from this current study for the Westlands-S and Westlands-D water-budget areas are given in figure 20. Surface-water delivery rates used for the current study are very close to those reported by Westlands Water District (1999). The pumpage rates estimated in the current study follow a similar trend to the estimates of Westland Water District (1996, 1999, 2004); however, the annual estimates from this current study are significantly higher for most years. The data set used in this study does not include surface-water transfers and, therefore, may overestimate ground-water pumpage if significant surface-water transfers occur within the district. The irrigation efficiencies of 72 to 94 percent reported by Westlands Water District (1999) are also significantly higher than the 66 percent reported by Burt and Katan (1988) and that reported for neighboring districts by Ayars and Schrale (1989) and the Irrigation Training and
Research Center (1994). It is possible therefore that the Westlands Water District $(1996,1999,2004)$ underestimated the annual irrigation demand and the total amount of ground water pumped within the district. It is also possible that the irrigation practices used in the Westlands WD result in lower irrigation demand than those used in the rest of the study area; for consistency, we have used a single methodology to estimate $R$ values for all the water-budget areas.

Deep percolation estimates from the current study and those of Summers Engineering (2002) are presented in table 9. Summers Engineering (2002) estimated a single value for Westlands WD; this single estimate is presented in table 9 along with estimates from this current study for the Westlands-D and Westlands-S water-budget areas. Although the two studies used very different methods, the results of the two studies are very similar for the Broadview WD, Firebaugh CWD, Pacheco WD, Panoche DD, and Westlands-S waterbudget areas. The differences between the two studies for the Westlands-D water-budget area most likely are due to the separate $R$ value used for the Westlands-D water-budget area for this current study. The deep percolation estimate for the CCID-Camp 13 water-budget area for this current study is very low, most likely due to insufficient data; the results for CCID-Camp 13 from Summers Engineering (2002) appear to be much more reasonable.

Table 9. Recharge estimates for 2000 for several water-budget areas in the Grasslands area of the central part of the western San Joaquin Valley, California.

[All values are in feet per year]

\begin{tabular}{lcc}
\hline & \multicolumn{2}{c}{ 2000 Recharge } \\
\cline { 2 - 3 } Water-budget areas & $\begin{array}{c}\text { Summers Engineering, } \\
\mathbf{2 0 0 2}\end{array}$ & This study \\
\hline Broadview WD & 0.55 & 0.52 \\
CCID-Camp 13 & .62 & .01 \\
Firebaugh CWD & .62 & .60 \\
Pacheco WD & .52 & .51 \\
Panoche DD & .54 & .56 \\
Westlands-D & .54 & .86 \\
Westlands-S & .54 & .53 \\
\hline
\end{tabular}




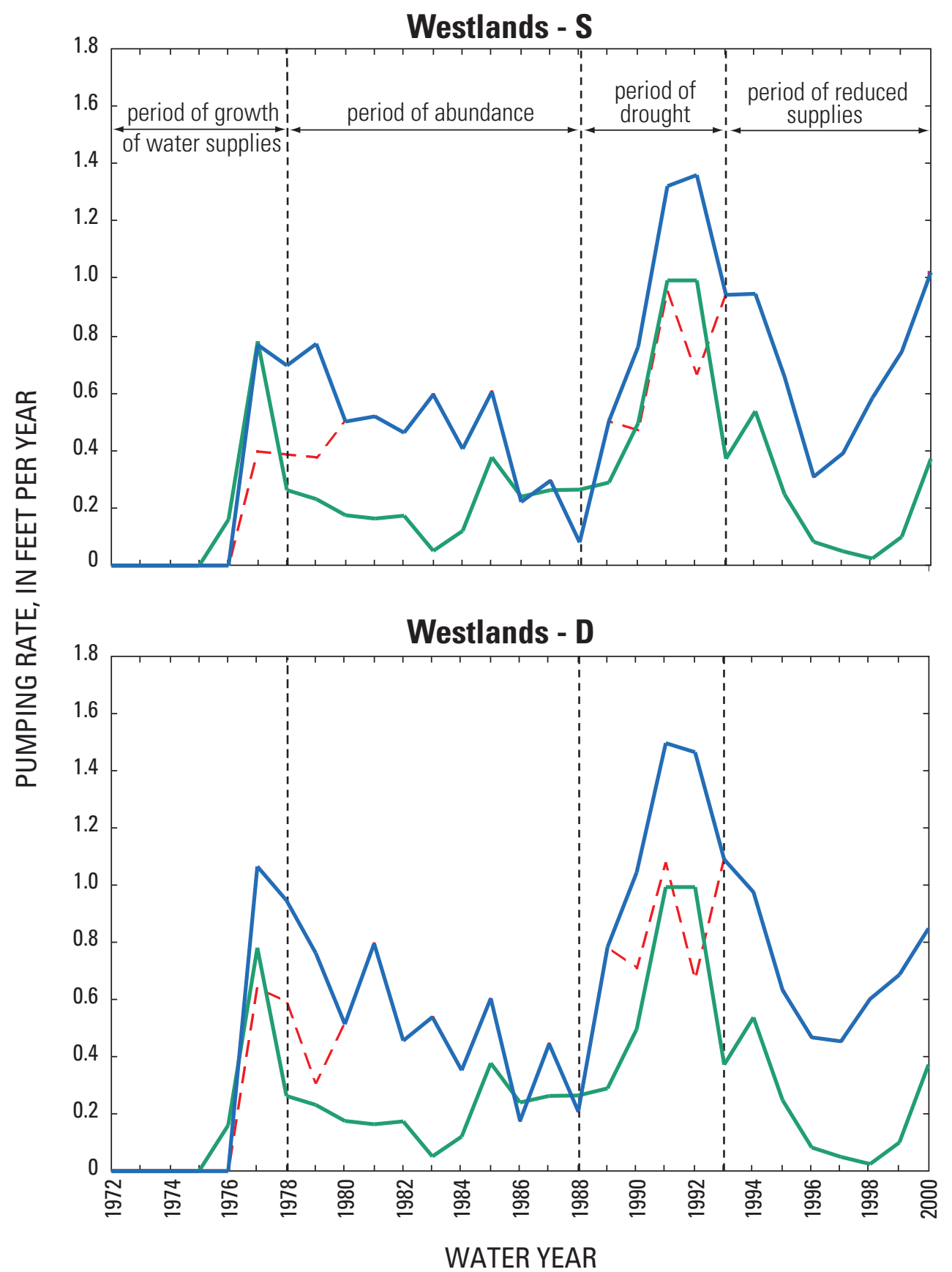

EXPLANATION

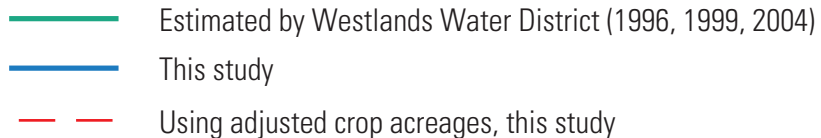

Figure 20. Estimates of annual pumpage rates for the Westlands-S and the Westlands-D water-budget areas in the Grasslands area of the central part of the western San Joaquin Valley, California, water years 1972-2000. 


\section{Aggregate Crop Coefficient}

Water budgets derived during this study were used to determine if a single parameter could be identified that would characterize annual crop water demands for agricultural areas in the study area. The relationship between the annual crop water demand for an agricultural area and $E T_{0}$ can be expressed using an aggregate crop coefficient. This relationship could be used in future studies to estimate crop water demands directly from $E T_{0}$, significantly reducing datacollection requirements. Annual values of this aggregate crop coefficient, termed $K_{d}$ for this study, may be calculated by dividing total annual crop water demand $\left(W_{s, y}\right)$ by total annual $E T_{0}\left(E T_{0}, y\right)$ and total crop acreage $\left(A_{s, y}\right)$ :

$$
K_{d, s}=W_{s, y} /\left(A_{s, y} * E T_{0, \mathrm{y}}\right),
$$

where $K_{d, s}$ is the $K_{d}$ value for water-budget area $s, y$ is the water year and

$$
E T_{0, y}=\sum_{i=1}^{\text {days }} E T_{0, i}
$$

The values of $K_{d}$ calculated for each water-budget area and for the total study area for each water year are plotted in figure 21 .

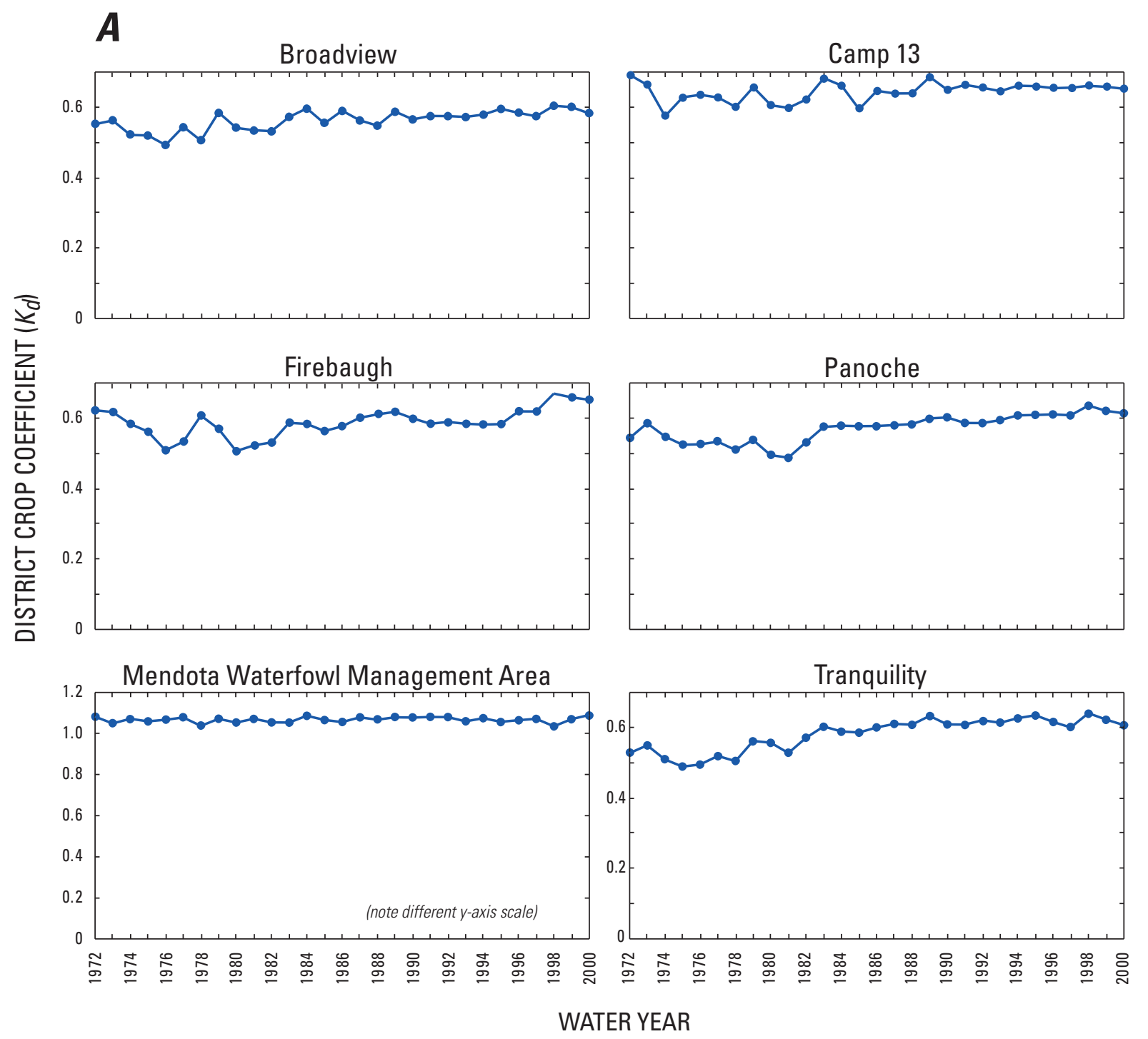

Figure 21. Crop coefficient $\left(K_{d}\right)$ for water-budget areas in the Grasslands area of the central part of the western San Joaquin Valley, California, water years 1972-2000. A, Water-budget areas that receive water from the Delta Mendota Canal (DMC), the Mendota Pool, and the Fresno Slough. $\boldsymbol{B}$, Water-budget areas that receive water from the San Luis Canal (SLC). 
$K_{d}$ is a district-wide measure of the potential crop water demand, an indicator of the water-use intensity (total crop water demand per cropped acre) of the cropping system. $K_{d}$ was nearly constant for the entire study area from 1983 to 2000 (fig. 21), with an average of 0.59 , and averaged 0.53 prior to 1983 , a period when a large part of the study area had begun receiving surface-water deliveries from the SLC. Most of the water-budget areas (with the exception of the Mendota WMA which is dominated by wetland plants) exhibit a similar pattern, with $K_{d}$ either remaining stable through time or rising prior to 1983 and then remaining fairly constant. The increase in $K_{d}$ between 1972 and 1982 suggests a change in the crop mix toward crops that use a greater amount of water. The stable $K_{d}$ after 1983 suggests that the water use per acre of the crop mix has remained constant. For future studies, it may be possible to accurately estimate total crop water demand by district as the product of $K_{d}$, cropped acreage, and total annual $E T_{0}$.

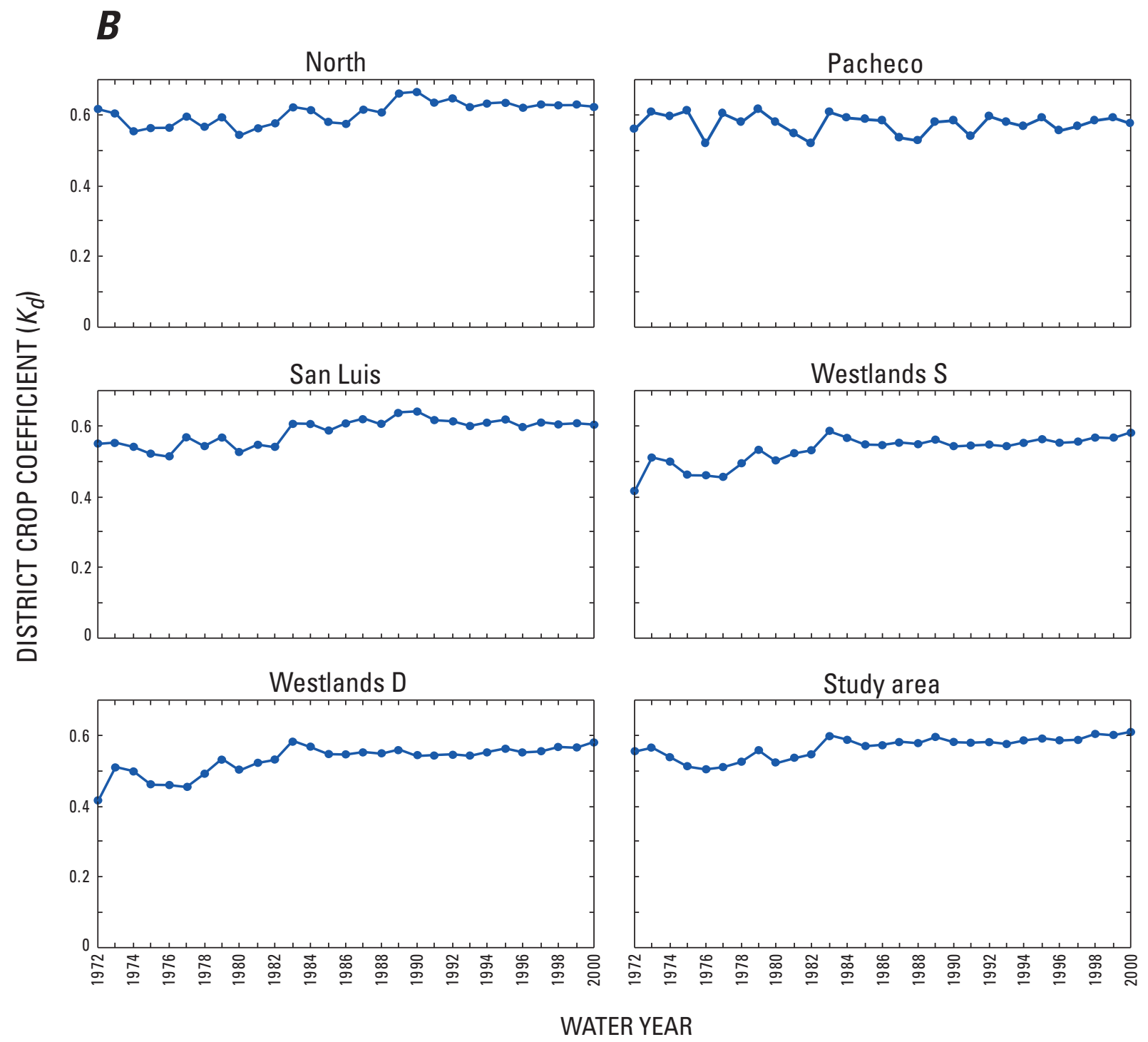

Figure 21. Continued. 


\section{Surface-Water Availability Indices}

The relationship between ground-water pumpage and each of the two surface-water availability indices (the cumulative departure from the mean surface-water delivery rate and the Sacramento Basin 40-30-30 Index) may link ground-water demand to climate forecasts. As figure 22 indicates, cropped area, surface-water deliveries, and ground-water pumping exhibit three patterns with respect to the CDM and SBI indices. Prior to 1980, surface-water delivery rates were increasing and there was little correlation between cropped area, surface-water deliveries, and ground-water pumping and either of the two indices. Crop acreages and surface-water deliveries per cropped acre have remained relatively stable since 1980 , with some reduction in drought years. Ground-water pumpage rates were highest in drought years; after 1980 pumpage rates generally were higher in years when the CDM was low. After 1980, cropped acreage, surface-water delivery rates, and ground-water pumpage rates exhibit a threshold behavior in response to the SBI. Significant reductions in cropped acreage and surface-water deliveries and significant increases in ground-water pumpage rates occurred in the years when the $\mathrm{SBI}$ value was less than approximately 4.5 million acre-ft.
Cropped area versus cummulative departure from the mean
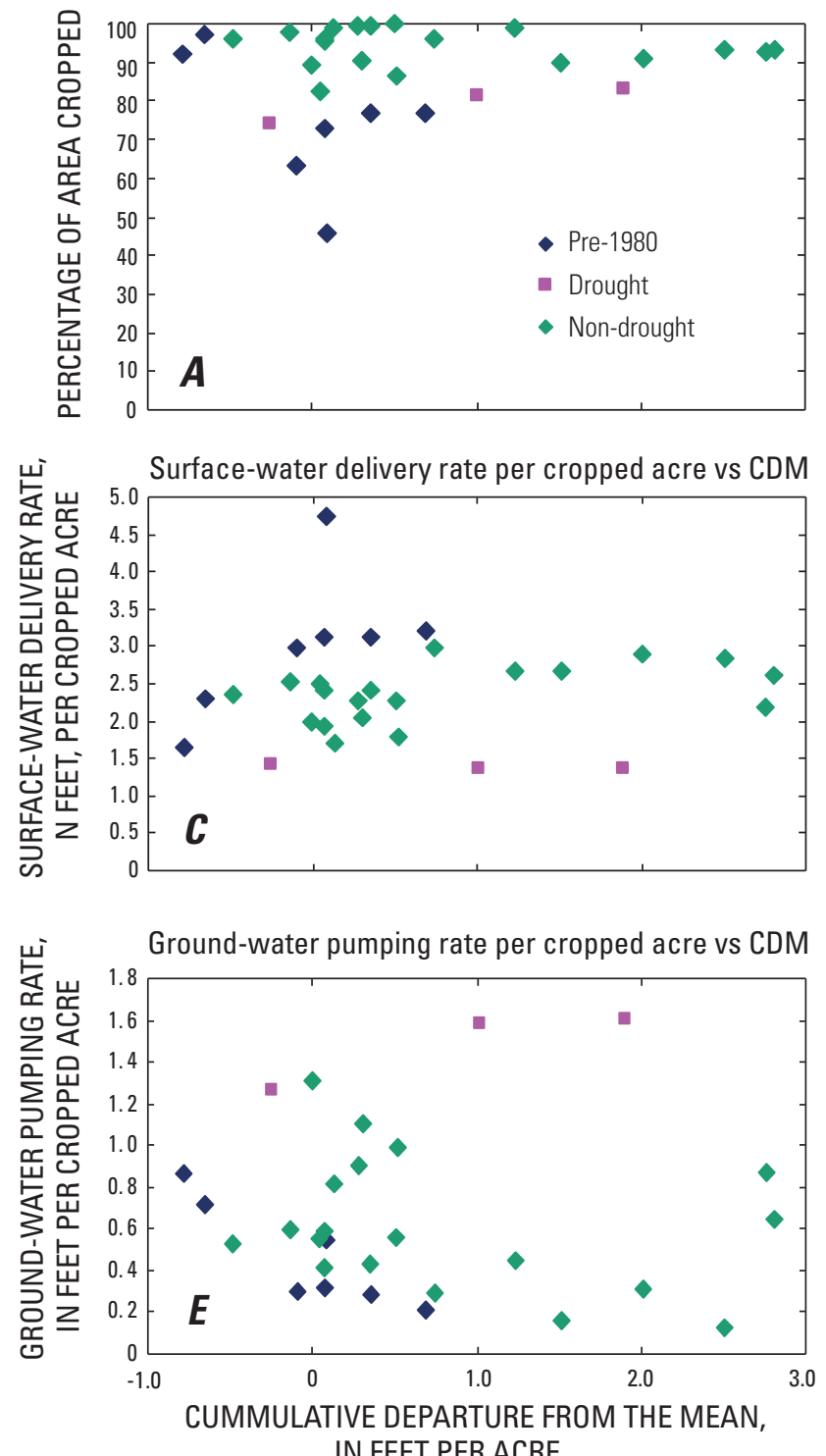

Cropped area versus Sacramento 40-30-30 index

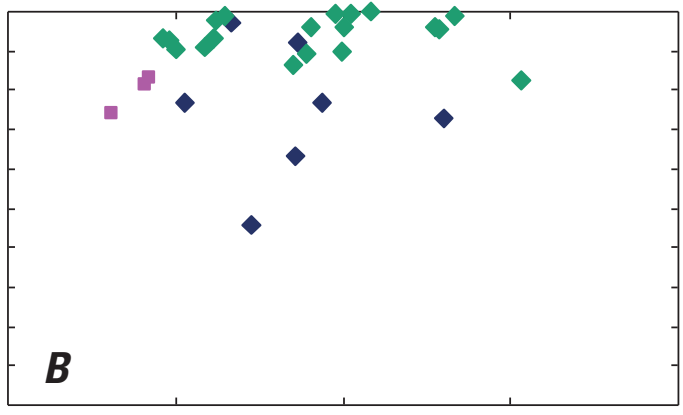

Surface-water delivery rate per cropped acre vs SBI

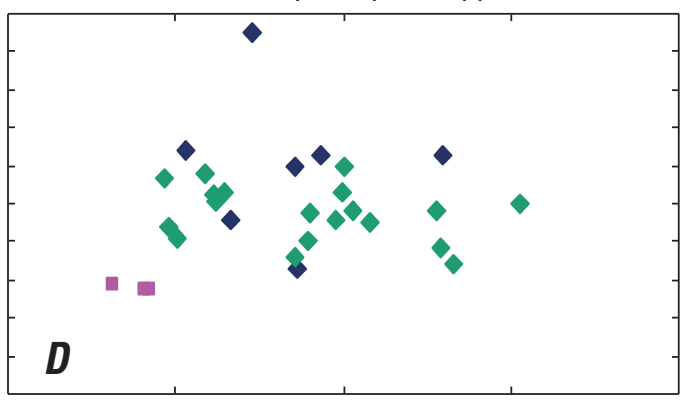

Ground-water pumping rate per cropped acre vs SBI

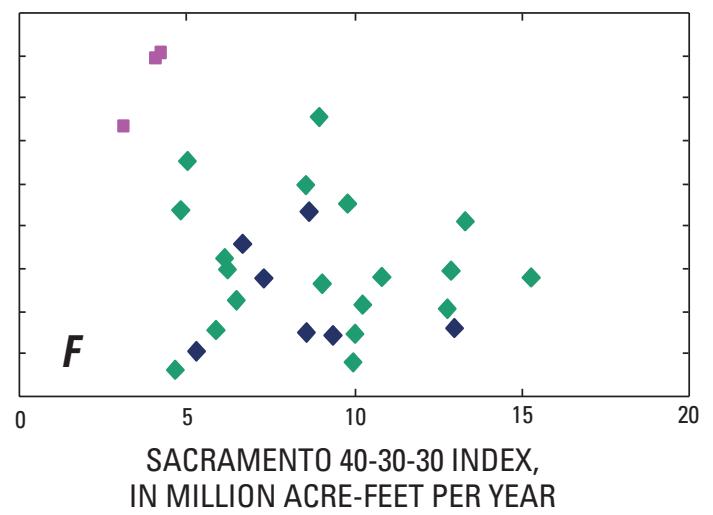

Figure 22. Percentage of acreage cropped, surface-water delivery rates, and estimated ground-water pumpage rates plotted against the cumulative departure from the mean surface water deliveries and the Sacramento Basin 40-30-30-Index for the Grasslands area of the central part of the western San Joaquin Valley, California, water years 1972-2000. 


\section{Estimation Sensitivity and Uncertainty}

Water budgets combine several models and therefore are sensitive to the parameters and inputs of the component models. Parameters of the soil-surface process model include the curve number; data include precipitation and $E T_{0}$. Parameters of the soil-moisture budget include a uniform field capacity and the rooting depth, planting date, and the $K_{c}$ curve for each crop; data include $E T_{0}$. Parameters of the water budget include $R$ for each water-budget area; data include crop acreages and surface-water deliveries. Sensitivity analysis assesses what effect uncertainties in each of the input parameters would have on model output. Sensitivities are reported here as percent change in the average pumpage rate and average recharge rate in response to a 1 percent change in the input parameter. The sensitivity of the water-budget model to the curve number, depth of crop root zone, $R$, and crop-acreage values are reported in table 10.

Table 10. Sensitivities of recharge and pumpage estimates to several input parameters of the water budget of Grasslands area of the central part of the western San Joaquin Valley, California.

[All values are in percent change in the simulated value in response to a 1 percent change in the input parameter]

\begin{tabular}{lcc}
\hline & $\begin{array}{c}\text { Sensitivity of re- } \\
\text { charge estimate }\end{array}$ & $\begin{array}{c}\text { Sensitivity of pump- } \\
\text { age estimate }\end{array}$ \\
\hline Curve number & -0.6 & 0.8 \\
Root-zone depth & -.2 & -.4 \\
$\begin{array}{l}\text { Consumption- } \\
\text { delivery ratio }(R)\end{array}$ & -3.0 & -6.0 \\
Cropped acreage & -.4 & 4.6 \\
\hline
\end{tabular}

The soil-surface process model has one parameter (curve number) and two data inputs (daily precipitation and evapotranspiration). Infiltration, and therefore effective precipitation, is a function of the curve number. Xie and others (2003) determined the results of a crop-based water-balance model were more sensitive to the runoff curve number than to precipitation or evapotranspiration. A reduction in the curve number would increase infiltration and provide more water for effective precipitation. A 5 percent reduction in the curve number resulted in a 3 percent increase in average annual recharge for a sensitivity of -0.6 and a 4 percent decrease in average annual pumpage for a sensitivity of 0.8 . These sensitivities are less than 1 , indicating the water-budget model is not very sensitive to the curve number.

Because of the limited availability of areally and temporally discrete crop acreage and irrigation delivery data for the Grasslands area, data were lumped into 11 water-budget areas for analysis. This lumping of crop acreages and irrigation water deliveries is expected to have a greater influence on model results than the lumping of soil types or climate data.
For example, Yu and others (2000) found that estimated runoff and evapotranspiration were more sensitive to distributed land use than to distributed soil type. Thus, although distributed soil type data are available, soils were lumped into a single average soil type for this study. Preliminary kriging of climate data (not shown) indicated very little variability in precipitation or $E T_{0}$ across the study area. No numerical analysis was performed to evaluate the sensitivity of the water budget to the use of distributed versus lumped data.

The depth of the rooting zone and the field capacity, which determine the size of the storage reservoir, are integral components of the daily crop soil-moisture budgets. Brisson and others (1992) found that their soil water-balance model was more sensitive to crop rooting depth and initial soilmoisture content than to the spatial variability in the soil texture. The sensitivity of the water-budget model used in this study to the size of the soil-moisture storage reservoir was assessed by reducing the crop rooting depth of all crops by 10 percent. This resulted in a 2 percent increase in recharge for a sensitivity of -0.2 , and a 4 percent increase in ground-water pumpage for a sensitivity of -0.4 . These sensitivities are less than 1 , indicating that the water-budget model is not very sensitive to the size of the water storage reservoir (which is a function of both field capacity and crop rooting depth).

For this study, consumption-distribution ratios $(R)$ were used in lieu of irrigation efficiencies; $R$ values generally are expected to be less than irrigation efficiencies. Although $R$ values are expected to vary with time, a single time-invariant $R$ value was used for each of the water-budget areas. The sensitivity of the water-budget model to $R$ values was assessed by increasing all $R$ values by 1 percent. This resulted in a 3 percent decrease in the average recharge rate for the study area, yielding a sensitivity of -3.0 , and a 6 percent decrease in the average ground-water pumpage rate, yielding a sensitivity of -6.0. The increase in $R$ resulted in ground-water pumpage declines to zero for some water-budget areas for some years. The water-budget model was extremely sensitive to the $R$ values used.

Crop acreage data are extremely important inputs to the water-budget model. However, much of the crop acreage data input to the model for this study was estimated. Data sources include prior-year estimates collected for planning purposes, area-weighted averages, and assumptions regarding regional planting preferences. Growers may have altered planting decisions on the basis of reductions in water deliveries or other factors. In addition, incomplete emergence of planted crops could result in a decrease in irrigated acreage. It is unlikely that incomplete emergence would play a significant role in reducing irrigation applications within a single field because of the significant management effort required to selectively irrigate portions of a field on the basis of crop emergence patterns. However, significant incomplete emergence could result in the abandonment of fields.

The sensitivity of the water-budget model to crop acreage data was analyzed by reducing all crop acreages by 5 percent. This resulted in a 2 percent increase in average recharge for 
a sensitivity of -0.4 , and a 22 percent decrease in average ground-water pumpage for a sensitivity of 4.6. The decreases in cropped acreage resulted in ground-water pumpage declines to zero for some water-budget areas for some years. Recharge is largely a function of surface-water delivery rates and $R$ values, which remain constant even as the crop acreage decreases. Ground-water pumpage rates are estimated as a function of the residual crop water demand after using surface-water deliveries, and thus are extremely sensitive to cropped acreage.

The sensitivity of the water-budget model to curve number, root-zone depth, $R$ value, and cropped acreage was investigated by assessing the impact that changes in these parameters would have on the estimates of average recharge and ground-water pumpage rates. Recharge estimates are a function of the surface-water delivery data and the $R$ values and are very sensitive to the $R$ values used. Ground-water pumpage was extremely sensitive to both the cropped acreage and the $R$ values. Neither recharge nor pumpage estimates were very sensitive to the curve number or to the crop rooting depth. Although crop acreage and surface-water delivery values are important inputs to the water-budget model, there is a lot of information available to constrain these inputs. The water-budget model also was extremely sensitive to the choice of $R$ values; there is little information available to constrain these values.

\section{Limitations of this Methodology}

Several simplifying assumptions were incorporated in the water-budget model used for this study. Precipitation and $E T_{0}$ data and soil properties were lumped for the entire study area. Crop acreages, surface-water deliveries, and consumptiondistribution ratios $(R)$ were lumped for each water-budget area; $R$ values were also assumed to remain constant throughout the study period. Crop water demand, estimated using a simple crop consumptive model with a uniform planting date and crop coefficient curve for each crop, was assumed to be uniform across the entire study area. Soil surface wetting processes were not correctly simulated. Instead, an aggregate areaweighted curve number and lumped climate data were used to estimate daily infiltration of precipitation. The insensitivity of the model to changes in the curve number indicate that daily infiltration of precipitation is less important than other components of the water budget.

The crop soil-moisture budget model, which estimates irrigation demand for each crop, also incorporates a number of simplifying assumptions. Spatial variability in cropping patterns and irrigation technologies are ignored, and the entire acreage of each crop is assumed to be planted on a single day. Daily crop water demand is assumed to equal the product of daily $E T_{0}$ and a calendar-based crop coefficient, ignoring the effects of reduced soil moisture. The lateral flux of ground water is assumed to be negligible, complete redistribution of soil moisture is assumed to occur within a 24-hour period, and both bare-soil evaporation and the upward flux of groundwater through the lower boundary of the model are assumed to be incorporated into the $R$ value of each water-budget area. Variability in crop water demand due to these factors is minor, as the insensitivity of model results to the depth of the crop root zone indicates.

The water-budget model aggregates annual crop acreage data, annual surface-water delivery data, and $R$ values for each water-budget area with estimated water demand for each crop. Much of the uncertainty associated with the water-budget model is due to the imprecise crop acreage data, surface-water delivery data, and the time-invariant $R$ values. The results of the water-budget model are most sensitive to $R$ values and crop acreage. The uncertainty of the $R$ values is large, as is reflected in the wide divergence in irrigation efficiency values reported in the study area. There is little information available to definitively estimate historical district-wide average $R$ values, but these values are expected to change over time as growers invest in irrigation technology and as districts increase recycling.

The lack of information regarding the volumes and timing of irrigation pumping is a major limitation of all water-management studies conducted on the west side of the San Joaquin Valley. The water-budget model developed for the Grasslands study area relies on the assumption that after applying all available surface water, growers will pump ground water until all crop water demands are met. Surface water and ground water are treated as perfectly substitutable inputs to production. However, ground water often is significantly more expensive than surface water, and generally is available only in fields in which operational wells and pumps are located. Thus, surface water and ground water ideally should be treated as separate, imperfectly substitutable inputs (Hooker and Alexander, 1998). Growers can use several management options when the surface-water supply is less than the crop irrigation requirement, including deficit irrigation (under-irrigating crops), increasing management efforts (resulting in a shortterm increase in $R$ values), and, in extreme cases, abandoning part or all of selected fields to concentrate available surfacewater deliveries in a smaller area. Therefore, the recharge and pumpage estimates reported in this report should be regarded as maximum values, which could be reduced if growers were reluctant or unable to pump enough ground water to meet the estimated crop irrigation water requirements.

These limitations are offset by the simplicity and ease of use of the water-budget model. This model provides baseline information regarding annual recharge and ground-water pumpage rates in the western part of the San Joaquin Valley. The simplicity of the model allows linkages between input parameters and model results to be easily assessed. The model is not sensitive to lumping of climate data, soil properties, and crop acreages within the study area. The model results, especially for ground-water pumpage, are most sensitive to input data regarding crop acreages and surface-water deliveries and to the $R$ values used for the water-budget areas. Significant effort currently is being expended in monitoring surface-water deliveries. More accurate estimation of ground-water pumpage will require monitoring ground-water pumpage and estimation of field-level and district-level irrigation efficiencies. 


\section{Summary}

A numerical ground-water flow model of the regional ground-water flow system in the central part of the western San Joaquin Valley is being developed as part of a project investigating sources and quantities of agricultural drain flows in the Grasslands area. Quantitative estimates of the areal and temporal distributions of ground-water recharge and groundwater pumpage are essential components of this model. A climate-based approach was used to estimate annual recharge to the water table and annual ground-water pumpage for 1972 through 2000 for 11 water-budget areas in the study area.

The study area was divided into 29 contiguous areas for data collection. The boundaries of many of these datacollection areas correspond to administrative boundaries. Detailed crop acreage data were not available for most years covered by this study. Coming-year crop acreage estimates, planning documents compiled by districts receiving Federal surface water, were often the only source of crop acreage data. Thus crop acreage data compiled for this study may not accurately reflect reductions in planted acreage or changes in crop mix in response to reduced availability of surface water during drought years. Reliable estimates of monthly surface water deliveries from public surface-water conveyances were compiled from reports published by the California Department of Water Resources and the U.S. Bureau of Reclamation. It is possible that minor additional surface water deliveries, including transfers between districts or growers, were not accounted for. Analysis of surface-water deliveries to the study area indicates the study period can be broken into four periods on the basis of trends in surface-water deliveries: increased deliveries from the San Luis Canal (1972-78), abundant surface water (1979-89), protracted drought (1990-93), and reduced surface water supplies (1994-2000).

The lack of information regarding the volumes and timing of ground-water pumpage by growers is a major limitation of all water-management studies conducted on the west side of the San Joaquin Valley. There is also little historical information regarding recycling of agricultural drain water by districts or on farms. For this study, ground-water pumpage was estimated as the remaining crop water demand after crop consumption of surface water.

This study employed a climate-based approach to estimate annual recharge to the water table and annual groundwater pumpage. A daily soil-moisture budget was developed for January 1, 1970, through September 30, 2000, for each of the crops grown in the study area to estimate annual values of total crop water demand, crop water demand not met with precipitation, and precipitation-derived recharge to the water table for each crop. The water budget combined output from the daily soil-moisture budget with crop acreage data, surface-water delivery data, and the consumption-distribution ratio (the portion of irrigation water consumed by crops) to estimate annual recharge and ground-water pumpage. Water budgets were initially calculated for each of the 29 data-col- lection areas. However, the temporal and spatial resolution of the crop acreage and surface-water delivery data were insufficient to support water budgets at this scale. The data-collection areas were therefore consolidated into 11 contiguous areas for water-budget calculations.

Ground-water pumpage estimates for the entire study area averaged $0.5 \mathrm{ft} / \mathrm{yr}$, ranging from a high of $1.2 \mathrm{ft} / \mathrm{yr}$ in 1991 to a low of $0.1 \mathrm{ft} / \mathrm{yr}$ in 1976 . Estimates of recharge for the entire study area averaged $0.8 \mathrm{ft} / \mathrm{yr}$, ranging from a high of 1.2 $\mathrm{ft} / \mathrm{yr}$ for 1972 to a low of $0.5 \mathrm{ft} / \mathrm{yr}$ for 1977. Four years of high rates of recharge from precipitation during the 6-year period 1993-98 may partly be responsible for increased discharges from agricultural drains.

The results of this study suggest that the climate-based approach provides reliable estimates of recharge and groundwater pumpage, provided adequate crop acreage and surfacewater delivery data area available. Ground-water pumpage estimates are extremely sensitive to both crop acreage and consumption-distribution ratios. Ground-water recharge is largely a function of the surface-water deliveries and the consumption-distribution ratio.

The water-budget estimation methods developed for this study were used to evaluate gaps in data and to investigate the kinds of data needed to characterize crop water demand for agricultural areas. An annual aggregate crop coefficient, $K_{d}$, was determined for each study area. $K_{d}$ was nearly constant with an average of 0.59 from 1983 to 2000, and relatively constant with an average value of 0.53 prior to 1983 . Thus, the annual crop water demand for an area may be estimated as the product of $K_{d}$, cropped acreage, and total $E T_{0}$.

\section{References Cited}

Allen, R.G., Pereira, L.S., Raes, D., and Smith, M., 1998, Crop evapotranspiration-guidelines for computing crop water requirements, FAO irrigation and drainage paper 56: Food and Agriculture Organization of the United Nations, Rome, Italy, variously paged.

Ayars, J.E., and Schrale, Gerrit, 1989, Irrigation efficiency and regional subsurface drain flow on the west side of the San Joaquin Valley: Final report on Contract b56488, submitted to California Department of Water Resources Office of Water Conservation, $120 \mathrm{p}$.

Belitz, Kenneth, and Heimes, F.J., 1990, Character and evolution of the ground-water flow system in the central part of the western San Joaquin Valley, California: U.S. Geological Survey Water-Supply Paper 2348, 28 p.

Belitz, Kenneth, Phillips, S.P., and Gronberg, J.M., 1993, Numerical simulation of ground-water flow in the central part of the western San Joaquin Valley, California: U.S. Geological Survey Water-Supply Paper 2396, 69 p. 
Brisson, Nadine, Seguin, Bernard, and Bertuzzi, Patrick, 1992, Agrometeorology of soil water balance for crop simulation models, Agricultural and Forest Meteorology, v. 59, p. 267-287.

Burt, Charles M., and Katen, Kenneth, 1988, 1986/1987 Water conservation and drainage reduction program, Technical report to the Office of Water Conservation, California Department of Water Resources on the Westside Resource Conservation District, 29 p.

California Avocado Commission, Crop coefficient $\left(K_{c}\right)$ for Avocado, accessed June 18, 2002, at http://www.avocado. org/static/growerres/cimis-cropcoefficient.html.

California Department of Water Resources, 2003, Chronological Reconstructed Sacramento and San Joaquin Valley Water Year Hydrologic Classification Indices, accessed March 15, 2004, at http://cdec.water.ca.gov/cgi-progs/iodir/ WSIHIST.

California Department of Water Resources, Hydrologic and Water Supply Conditions, accessed March 15, 2004, at http://watsup2.water.ca.gov/hydrologic.cfm.

California Department of Water Resources, Evapotranspiration measurements for the CIMIS station at Firebaugh, CA, accessed June 18, 2002, at http://www.ipm.ucdavis.edu/calludt.cgi/WXSTATIONDATA?STN=FIREBAGH.A.

California Department of Water Resources, Precipitation and evapotranspiration measurements for the CIMIS station at Five Points, CA, accessed June 18, 2002, at http://www.ipm. ucdavis.edu/calludt.cgi/WXSTATIONDATA?STN=FIVE_ PTS.A.

California Department of Water Resources, Precipitation and evapotranspiration measurements for the CIMIS station at Panoche, CA, accessed June 18, 2002, at http://www.ipm. ucdavis.edu/calludt.cgi/WXSTATIONDATA?STN=PANOC HE.A.

California Department of Water Resources, Precipitation measurements for the NCDC station at Five Points, CA, accessed June 18, 2002, at http://www.ipm.ucdavis.edu/calludt.cgi/WXDESCRIPTION?STN=FIVE_PTS.C.

California Department of Water Resources, Precipitation measurements for the NCDC station at Los Banos, CA, accessed June 18, 2002, at http://www.ipm.ucdavis.edu/calludt.cgi/WXSTATIONDATA?STN=LOSBANOS.C.

California Department of Water Resources, Precipitation measurements for the NCDC station at Madera, Calif., accessed June 18, 2002, at http://www.ipm.ucdavis.edu/calludt. cgi/WXSTATIONDATA?STN=MADERA.C.

California Department of Water Resources, 1971-2001, Annual report of operations, Central Valley Project: various pages.
Canessa, Peter, and Smith, Chris, 1992, A study of two methods for estimating gross groundwater extractions - water meters and power records: Monterey County Water Resources Agency, Monterey, Calif., 70 p.

Center for Agroecology and Sustainable Food Systems, University of California, Santa Cruz, CA, accessed December 23, 2003, at http://zzyx.ucsc.edu/casfs/gardenideas/citrus. html.

Center for Irrigation Technology, California State University, Fresno, Calif., accessed June 18, 2002 at http://www. wateright.org/site $2 /$ reference/kcreport.asp.

Deverel, S.J., Gilliom, R.J., Fujii, Roger, Izbicki, J.A., and Fields, J.C., 1984, Areal distribution of selenium and other inorganic constituents in shallow ground water of the San Luis Drain service area, San Joaquin Valley, California: A preliminary study: U.S. Geological Survey Water-Resources Investigations Report 84-4319, 67 p.

Fio, J.L., 1994, Calculation of a water budget and delineation of contributing sources to drainflow in the western San Joaquin Valley, California: U.S. Geological Survey Open-File Report 94-45, 39 p.

Gilliom, R.J., and others, 1989, Preliminary assessment of sources, distribution, and mobility of selenium in the San Joaquin Valley, California: U.S. Geological Survey WaterResources Investigations Report 88-4186, 129 p.

Gronberg, J.M., and Belitz, Kenneth, 1992, Estimation of a water budget for the central part of the western San Joaquin Valley, California: U.S. Geological Survey Water-Resources Investigations Report 91-4192, 22 p.

Hanson, B., Schwankl, L., and Fulton, A., 1999, Scheduling irrigations: when and how much water to apply: Division of Agriculture and Natural Resources, University of California, Berkeley, Calif., variously paged.

Hooker, Mark A., and Alexander, Wendy E., 1998, Estimating the demand for irrigation water in the Central Valley of California, Journal of the American Water Resources Association, v. 34, p. 497-505.

Ireland, R.L., Poland, J.F., and Riley, F.S., 1984, Land subsidence in the San Joaquin Valley, California, as of 1980: U. S. Geological Survey Professional Paper 437-I, 93 p.

Irrigation Training and Research Center, 1994, Grassland Basin irrigation and drainage study: Irrigation Training and Research Center, California Polytechnic State University, San Luis Obispo, Calif., variously paged.

Letey, J., Williams, C.F., and Alemi, M., 2002, Salinity, drainage and selenium problems in the Western San Joaquin Valley, California, Irrigation and Drainage Systems, v. 16, p. 253-259. 
Presser, T.S., and Barnes, Ivan, 1985, Selenium concentrations in waters tributary to and in the vicinity of the Kesterson National Wildlife Refuge, Fresno and Merced Counties, California: U.S. Geological Survey Water-Resources Investigations Report 85-4220, 73 p.

San Luis and Delta-Mendota Water Authority, 1995, 1994 Delta-Mendota Canal groundwater pump-in program: San Luis and Delta-Mendota Water Authority, Los Banos, Calif., variously paged.

Snyder, R.L., Lanini, B.J., Shaw, D.A., and Pruitt, W.O., $1987 \mathrm{a}$, Using reference evapotranspiration $\left(E T_{0}\right)$ and crop coefficients to estimate crop evapotranspiration $\left(E T_{c}\right)$ for agronomic crops, grasses, and vegetable crops: Leaflet 21427, Cooperative Extension of the University of California, Division of Agriculture and Natural Resources, Berkeley, Calif., 12 p.

Snyder, R.L., Lanini, B.J., Shaw, D.A., and Pruitt, W.O., 1987b, Using reference evapotranspiration $\left(E T_{0}\right)$ and crop coefficients to estimate crop evapotranspiration $\left(E T_{c}\right)$ for trees and vines: Leaflet 21428, Cooperative Extension of the University of California, Division of Agriculture and Natural Resources, Berkeley, Calif., 8 p.

Summers Engineering, 2002, San Luis drainage feature reevaluation source control memorandum, white paper 1, June 17: URS Corporation, Oakland, Calif., 8 p.

Templin, W.E., Halton, T.C., and others, 1994, Irrigation water supply and demand data for 1976, 1980, and 1984 for the Western San Joaquin Valley, California: U. S. Geological Survey Open-File Report 94-335, 8 p.

Turner, R.L., 2002, Memorandum to the technical files: Seepage investigations along the San Luis Canal/California Aqueduct at mile 89.5 (approximate station 1040+00) near Eagle Field Road - Central Valley Project, California: U. S. Bureau of Reclamation, Sacramento, Calif., variously paged.

U.S. Bureau of Reclamation, 1953, Firebaugh Drainage Investigation: U. S. Bureau of Reclamation, Sacramento, Calif., variously paged.

U.S. Bureau of Reclamation, 1970-2000, Crop production reports, variously paged.

U.S. Department of Agriculture Natural Resources Conservation Service, 1999, Soil Survey of Merced County, California, Western Part: USDA Natural Resources Conservation Service, accessed June 8, 2004, at http://www.ncgc.nrcs. usda.gov/branch/ssb/products/ssurgo/data/ca.html.
U.S. Department of Agriculture Natural Resources Conservation Service, 2003, Soil Survey of Fresno County, California, Western Part: USDA Natural Resources Conservation Service, accessed June 8, 2004, at http://www.ncgc.nrcs. usda.gov/branch/ssb/products/ssurgo/data/ca.html.

U.S. Department of Agriculture Soil Conservation Service, 1912, Soil survey of the Fresno area, California: USDA Soil Conservation Service, variously paged.

U.S. Department of Agriculture Soil Conservation Service, 1970, Engineering field manual: Chapter 2, Estimating Runoff: USDA Soil Conservation Service, variously paged.

U.S. Department of Agriculture Soil Conservation Service, 1972, National engineering handbook: Section 4, Hydrology: USDA Soil Conservation Service, variously paged.

U.S. Department of Agriculture Soil Conservation Service, 1990, Soil survey of Merced County, California, Western Part: USDA Soil Conservation Service, variously paged.

Westlands Water District, 1996, Ground-water Management Plan: Westlands Water District, Fresno, Calif., 32 p.

Westlands Water District, 1999, Water Management Plan: Westlands Water District, Fresno, Calif., 145 p.

Westlands Water District, 2001, Distribution System Map: Westlands Water District, Fresno, Calif., 1 p.

Westlands Water District, 2004, Westlands' Water Supply: Westlands Water District, Fresno, Calif., accessed June 22, 2004, at http://www.westlandswater.org/resources/watersupply/supply.asp.

Xie, Yun, Kiniry, J. R., and Williams, J. R., 2003, The ALMANAC model's sensitivity to input variables, Agricultural Systems, v. 78, p. 1-16.

Yu, Zhongbo, Gburek, W. J., and Schwartz, F. W., 2000, Evaluating the spatial distribution of water balance in a small watershed, Pennsylvania: Hydrological Processes, v. 14, p. 941-956. 


\section{Appendix A. Agroclimatic Data}

This appendix contains climate and crop acreage data used in the crop-based daily soil-moisture budgets. The data are available at http://pubs.water.usgs.gov/sir2004-5180. The file Climate.txt contains reference evapotranspiration $\left(E T_{0}\right.$, in/ day), precipitation (in/day), and maximum daily air temperature for the central part of the western San Joaquin Valley.

The remaining files contain crop acreages for the datacollection areas. Some areas represent an entire water district, and the other areas represent either a part of a water district or contiguous areas that are within a district.

\begin{tabular}{ll}
\hline Water district & \multicolumn{1}{c}{ File } \\
\hline Broadview WD & BWD.txt \\
CCID (Camp-13 area) & Camp-13.txt \\
CCID & CCID-NW.txt \\
CCID & CCID-SE.txt \\
CCID (Charleston DD) & CCID-Ch.txt \\
Eagle Field WD & EF.txt \\
Firebaugh CWD & FCWD.txt \\
Fresno Slough WD & FS.txt \\
James ID & JID.txt \\
Mercy Springs WD & MS.txt \\
Oro Loma WD & OL.txt \\
Panoche WD & PeWD.txt \\
Pacheco WD & PoWD.txt \\
San Luis WD & SL-A.txt \\
San Luis WD & SL-B.txt \\
San Luis WD & SL-C.txt \\
San Luis WD (Chareston DD) & SL-Ch.txt \\
Tranquility ID & TID.txt \\
Westlands WD (P-I) & WWD-ID.txt \\
Westlands WD (P-I) & WWD-IS.txt \\
Westlands WD (P-II) & WWD-2.txt \\
Westlands WD (P-III) & WWD-3.txt \\
Widren WD & Widren.txt \\
(Receive SW from CCID) & Other.txt \\
(Near Firebaugh - no SW) & Sagouspe.txt \\
(Near Mendota - no SW) & NoDist.txt \\
(Receive SW from CCID) & Duck.txt \\
Mendota Waterfowl MA & MWMA.txt \\
(Natural areas - no SW) & Natural.txt \\
The entire study area & Totalt \\
\hline
\end{tabular}

\section{Appendix B. Water Deliveries and District-Level Pumpage}

The water delivery data are aggregated by water-budget area. Files for these data are available at http://pubs.water. usgs.gov/sir2004-5180.

There are four water delivery data files; all values for these data are in acre-feet per water year:

- SWDeliveries.txt - Surface water imported into the area

- DistGWExport.txt - Ground water pumped in the area and exported

- DistGWUsed.txt - Ground water pumped and used within the area

- Recycled.txt - Recycled drain and tile water

The following four files contain the water delivery volumes (above) divided by the total acreage of the water-budget area and are presented in feet per water year:

- SWDelivRate.txt - Surface water imported into the area

- DistGWExRate.txt - Ground water pumped in the area and exported

- DistGWUsedRate.txt - Ground water pumped and used within the area

- RecycleRate.txt - Recycled drain and tile water

The water-budget areas were aggregated from the datacollection areas as follows:

\begin{tabular}{|c|c|c|}
\hline $\begin{array}{c}\text { Water- } \\
\text { budget area }\end{array}$ & No. & Data-collection areas \\
\hline $\begin{array}{l}\text { Broadview } \\
\text { WD }\end{array}$ & 1 & Broadview WD \\
\hline Camp-13 & 2 & CCID Camp-13 \\
\hline Firebaugh & 3 & $\begin{array}{l}\text { Firebaugh CWD, CCID-SE, Widren WD,No } \\
\text { District and Sagouspe }\end{array}$ \\
\hline MWMA & 4 & Mendota WMA and Natural \\
\hline North & 5 & $\begin{array}{l}\text { CCID-NW, CCID-Charleston, San Luis- } \\
\text { B,San Luis-C and San Luis-Charleston }\end{array}$ \\
\hline Pacheco & 6 & Pacheco WD \\
\hline
\end{tabular}




\begin{tabular}{|c|c|c|}
\hline $\begin{array}{l}\text { Water- } \\
\text { budget area }\end{array}$ & No. & Data-collection areas \\
\hline Panoche DD & 7 & $\begin{array}{l}\text { Panoche Drainage District (Panoche } \\
\text { WD,Eagle Field WD, Mercy Springs } \\
\text { WD, Oro Loma WD), Other Areas and } \\
\text { Duck Club }\end{array}$ \\
\hline San Luis & 8 & San Luis-A \\
\hline Tranquility & 9 & $\begin{array}{l}\text { Tranquility ID, James ID and Fresno Slough } \\
\text { WD }\end{array}$ \\
\hline $\begin{array}{l}\text { Westlands- } \\
\quad \text { D }\end{array}$ & 10 & WWD-ID, WWD-2 and WWD-3 \\
\hline Westlands-S & 11 & WWD-IS \\
\hline Total & 12 & The entire study area \\
\hline
\end{tabular}

\section{Appendix C. Soil-Moisture Budget Results}

Intermediate input and output files used in the crop soilmoisture budget programs are available at http://pubs.water. usgs.gov/sir2004-5180.

File Kc_table.txt contains the crop-specific $K_{c}$ functions needed to estimate crop evapotranspirative demand $\left(E T_{c}\right.$, in/day) from reference evapotranspiration ( $E T_{0}$, in/day): $E T_{c}$ $=E T_{0} \times K_{c}$. File RunoffFunction.txt contains daily runoff as a function of daily precipitation and the USDA-SCS curve number.

The five output files from the daily crop soil-moisture budget calculations are

- TotalDemandSum.txt

- MetDemandSum.txt

- UnmetDemandSum.txt

- DeepPercPrecipSum.txt

- PrecipInfilRunoffET Sum.txt
- Water-year crop water demand

- Water-year crop water demand met with precipitation

- Remaining water-year crop water demand after accounting for effective precipitation

- Recharge from precipitation

- Water-year precipitation, infiltration, runoff, and remaining evapotranspirative demand after accounting for evaporation of precipitation

\section{Appendix D. Water-Budget Results}

Pumpage and recharge volumes and rates for each waterbudget area for water years 1972 through 2000 are at http:// pubs.water.usgs.gov/sir2004-5180.

- PumpVolume.txt

- RechargeVolume.txt

- PumpRate.txt

- RechargeRate.txt
Estimate of the annual volume of ground water pumped in each water-budget area Estimate of the annual volume of ground-water recharge in each water-budget area Estimate of the annual groundwater pumpage rate in each water-budget area Estimate of the annual recharge rate in each water-budget area 